\title{
WestVirginiaUniversity
}

THE RESEARCH REPOSITORY @ WVU

Graduate Theses, Dissertations, and Problem Reports

2010

\section{Three essays on institutions and economic development}

\author{
Sanjukta Roy \\ West Virginia University
}

Follow this and additional works at: https://researchrepository.wvu.edu/etd

\section{Recommended Citation}

Roy, Sanjukta, "Three essays on institutions and economic development" (2010). Graduate Theses, Dissertations, and Problem Reports. 3111.

https://researchrepository.wvu.edu/etd/3111

This Dissertation is protected by copyright and/or related rights. It has been brought to you by the The Research Repository @ WVU with permission from the rights-holder(s). You are free to use this Dissertation in any way that is permitted by the copyright and related rights legislation that applies to your use. For other uses you must obtain permission from the rights-holder(s) directly, unless additional rights are indicated by a Creative Commons license in the record and/ or on the work itself. This Dissertation has been accepted for inclusion in WVU Graduate Theses, Dissertations, and Problem Reports collection by an authorized administrator of The Research Repository @ WVU.

For more information, please contact researchrepository@mail.wvu.edu. 


\title{
Three Essays on Institutions and Economic Development
}

\author{
Sanjukta Roy \\ Dissertation submitted to the \\ College of Business and Economics \\ at West Virginia University in partial \\ fulfillment of the requirements for the degree of \\ Doctor of Philosophy \\ in \\ Economics \\ Santiago M. Pinto, Ph.D., Chair \\ Russell S. Sobel, Ph.D. \\ Ronald J. Balvers, Ph.D. \\ Santosh Mishra, Ph.D. \\ Subhayu Bandopadhyay, Ph.D. \\ Department of Economics \\ Morgantown, West Virginia \\ 2010
}

Keywords: Institutions, Economic Development

Copyright 2010 Sanjukta Roy 


\section{Abstract \\ Three Essays on Institutions and Economic Development}

\section{Sanjukta Roy}

This dissertation consists of three essays that look into different types of institutions and their relation with various aspects of economic development. The essays explore the role of financial institutions, political institutions and the role of a free media in the context of economic development. Chapter 2 elaborates on how foreign direct investment (henceforth FDI) inflow into an economy can contribute towards the freedom of the institution of media. Chapter 3 analyzes how a free media can help mitigate terrorism incidents and strengthen a democracy for the same cause. Chapter 4 investigates how the development of financial institutions, namely financial intermediaries, helps in deconcentration of urban centers and promotes orderly urbanization.

Chapter 2 titled The Impact of Foreign Direct Investment on Press Freedom establishes foreign direct investment (FDI) as a major determinant of media freedom. Global integration can strengthen the media sector financially, make it technologically enhanced and can also improve the economic environment as a whole. This, in turn, would work towards the enhancement of media freedom. The sample includes high, middle and low income economies. Using a panel of 115 countries over a period of 20 years, our results reveal that FDI is an absolute necessity for a free and efficient media. The results are robust to various alternate specifications and inclusion of additional control variables.

Chapter 3 titled Countering Terror: The Importance of a Free Press establishes the importance of a free press in combating terrorism. Considering the case of transnational terrorism, the robust empirical analysis establishes that a free press mitigates impacts of terrorism. The analysis further substantiates that though a democracy by itself if often criticized as being terror-inviting, when empowered by a free press, the two together has a definite terror dampening effect.

Chapter 4, Counting on Financial Development for Urbanization examines the extent to which the level of a country's financial development play a contributory role in determining the pace of urbanization nad urban concentration in different countries. The empirical analysis spanning a 30 year period for 117 developed and developing countries show that a higher level of financial development is associated with a lower growth in urbanization and urban concentration. The results are found to be driven mostly by the experiences of developing countries. 


\section{Dedication}

I dedicate this dissertation to my parents. Without their support and encouragement, I would not have become the person I am today. I am indebted to them for life and owe to them every success of mine. 


\section{Acknowledgements}

I would like to acknowledge several individuals who have played an important role in my graduate education. I would like to thank my committee members Santiago Pinto, Russell Sobel, Ronald Balvers, Santosh Mishra and Subhayu Bandopadhyay for their time, valuable feedback and constant guidance. I am thankful to Dr. Pinto for being a wonderful advisor and an excellent teacher. My endeavor would not have been a success without his encouragement and guidance. I would always be indebted to Dr. Sobel for being the inspiration that has shaped my research. Without his support and encouragement at every step of my way, I would not have become the researcher that I am today. I am also grateful to Dr. Balvers, Dr. Mishra and Dr. Bandopadhyay for being so reachable and helpful everytime I needed an advice, even on things unimportant.

I want to take this opportunity to thank my colleague, coauthor and friend Nabamita. She has been an inspiration and the true friend, philosopher and guide I look up to. I am also thankful to my classmates and colleagues for making my graduate life memorable.

Finally, I want to thank my parents, who have been the pillar of strength throughout and my dear friend Supriyo whose commitment and support enabled me to stand strong and reach my goal. 


\section{Contents}

$\begin{array}{ll}\text { Abstract ii } & \text { ii }\end{array}$

$\begin{array}{lll}1 & \text { Introduction } & 1\end{array}$

$\begin{array}{|lll|}2 & \text { The Impact of Foreign Direct Investment on Press Freedom } & 8\end{array}$

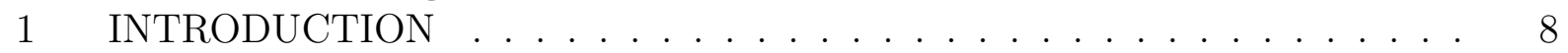

2 THE ROLE OF FOREIGN DIRECT INVESTMENT . . . . . . . . . . . . . 11

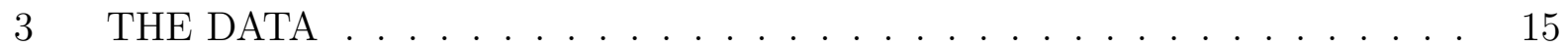

4 THE EMPIRICAL CONNECTION $\ldots \ldots \ldots \ldots \ldots$

5 ORDERED PROBIT SPECIFICATION . . . . . . . . . . . . . . 21

6 ROBUSTNESS $\ldots \ldots \ldots \ldots \ldots \ldots \ldots$

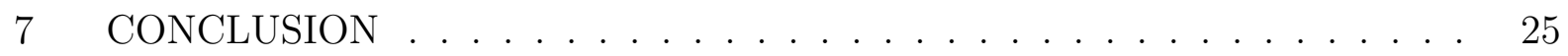

3 Countering Terror: The Importance of a Free Press 36

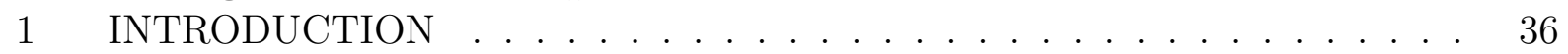

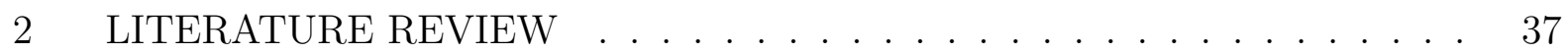

3 MOTIVATION and HYPOTHESIS $\ldots \ldots \ldots \ldots$. . . . . . . . . . . . . . . 39

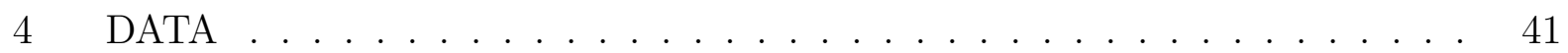

5 METHODOLOGY $\ldots \ldots \ldots \ldots \ldots \ldots$. . . . . . . . . . . . . . . . 44

$6 \quad$ RESULTS $\ldots \ldots \ldots \ldots \ldots \ldots \ldots$

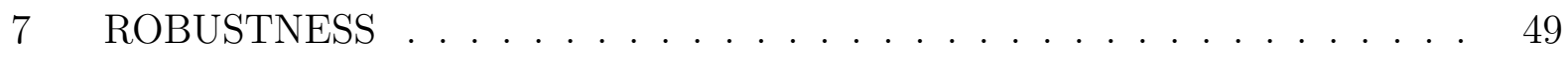

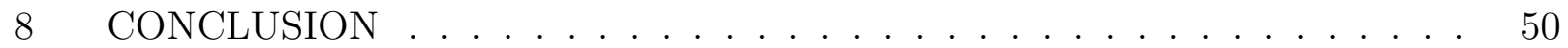

$\begin{array}{|lll|}4 & \text { Counting on Financial Development for Urbanization } & 64\end{array}$

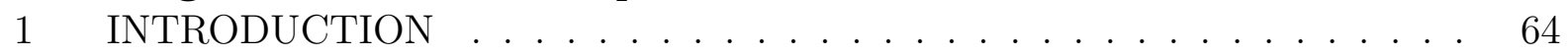

2 LITERATURE REVIEW $\ldots \ldots \ldots \ldots \ldots$. . . . . . . . . . . . . 65

3 HYPOTHESIS $\ldots \ldots \ldots \ldots \ldots \ldots$

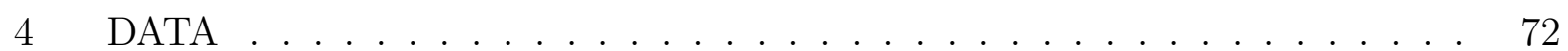

5 EVIDENCE FROM RAW DATA . . . . . . . . . . . . . . . . 75

$6 \quad$ EMPIRICAL RESULTS $\ldots \ldots \ldots \ldots \ldots \ldots \ldots$. . . . . . . . . . . . . 77

$7 \quad$ CONCLUSION $\ldots \ldots \ldots \ldots \ldots$. . . . . . . . . . . . . . . . 81

$\begin{array}{llr}5 \text { Conclusion } & 106\end{array}$

\begin{tabular}{lr}
\hline Bibliography & 108
\end{tabular} 
Curriculum Vitae 


\section{List of Figures}

2.1 The Association between Foreign Direct Investment Inflows and Press Freedom (Whole Sample)) . . . . . . . . . . . . . . . 27

2.2 The Association between Foreign Direct Investment Inflows and Press Freedom (Specific Years)) f . . . . . . . . . . . . . . . 28

2.3 The Association between FDI and Press Freedom; Note: $\mathbf{0}=$ 'Not Free'; 1 ='Partly Free'; 2 ='Free') . . . . . . . . . . . . . . . . . . 29

2.4 The Association between FDI and Press Freedom; Note: $0=$ 'Not

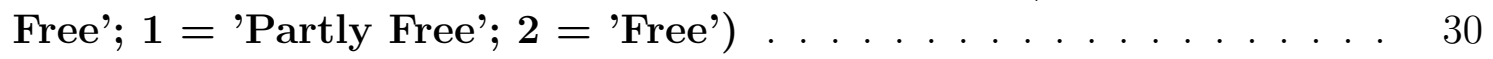

3.1 Impact of levels of Press Freedom on Incidents of Terrorism (for given levels of democracy) $\quad \ldots \ldots \ldots \ldots$. . . . . . . . . . . . . . . . . 62

3.2 Scatter Plot of Raw Data: Level of Press Freedom and Number of Terrorism Incidents) . . . . . . . . . . . . . . . . . . . . 63

$4.1 \quad$ Scatter plot for Whole sample for Share of Urban to Total Population 83

4.2 Scatter plot for Whole sample for H-F Index of Urban Concentration 84

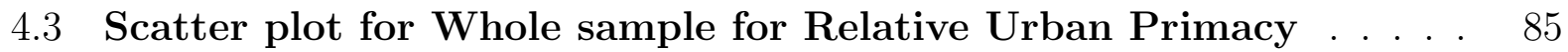

4.4 Scatter plot for Whole sample for Urban Gigantism . . . . . . . . . . 86

4.5 Scatter plot for Share of Urban to Total Population (Developing

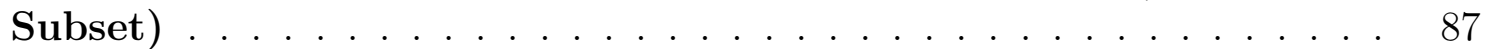

4.6 Scatter plot for Share of H-F Index of Urban Concentration (Developing Subset) $\ldots \ldots \ldots \ldots$. . . . . . . . . . . . . . . 88

4.7 Scatter plot for Share of Relative Urban Primacy (Developing Subset) 89

\begin{tabular}{|ll|l|l}
\hline 4.8 & Scatter plot for Share of Urban Gigantism (Developing Subset) & . . 90
\end{tabular}

4.9 Scatter plot for Share of Urban to Total Population (Developed

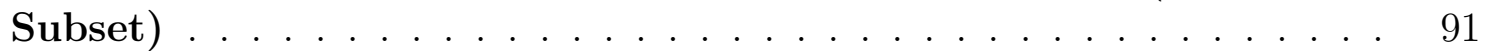

4.10 Scatter plot for Share of H-F Index of Urban Concentration (Developed Subset)

4.11 Scatter plot for Share of Relative Urban Primacy (Developed Subset) 93

4.12 Scatter plot for Share of Urban Gigantism (Developed Subset) . . . 94

4.13 Fitted Graph for Whole Sample . . . . . . . . . . . . . . . . . . . . . . 95

4.14 Fitted Graph for Whole Sample (with no cross term with Developed Country Dummy) f. . . . . . . . . . . . . . . . . . . 96

4.15 Fitted Graph for Developing Countries . . . . . . . . . . . . . . . . . . 97

4.16 Fitted Graph for Developed countries . . . . . . . . . . . . . . . . . . . 98 


\section{List of Tables}

2.1 OLS and Ordered Probit Showing Impact of FDI on Press Freedom 31

2.2 2SLS and Ordered-Probit with 2SLS Showing Impact of FDI on Press Freedom . . . . . . . . . . . . . . . . . . . 32

2.3 OLS and Ordered Probit with Alternative Measure of FDI . . . . . 33

2.4 List of Countries . . . . . . . . . . . . . . . . . . . . . 34

2.5 Data Sources . . . . . . . . . . . . . . . . . . . . . 35

$3.1 \quad$ The Impact of a Free Press on Future Incidents of Terrorism . . . . 52

3.2 The Impact of a Free Press on Future Incidents of Terrorism, Controlling for Democracy . . . . . . . . . . . . . . . . . . 53

3.3 The Impact of a Free Press on Future Incidents of Terrorism, Controlling for Political Right and Civil Liberty . . . . . . . . . . . . . . . 54

3.4 The Impact of a Free Press on Future Incidents of Terrorism, Indi-

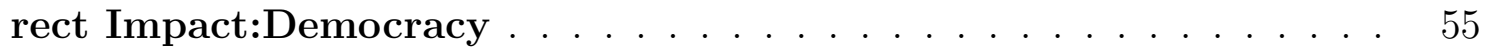

3.5 The Impact of a Free Press on Future Incidents of Terrorism, Indirect Impact: PR-CL . . . . . . . . . . . . . . . . . . . . . . . . . . . . . . 56

$3.6 \quad$ The Impact of a Free Press on Future Incidents of Terrorism, Cross

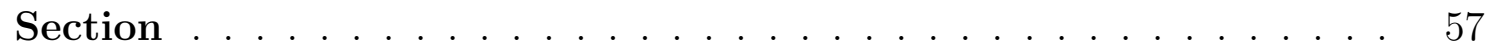

3.7 The Impact of a Free Press on Future Incidents of Terrorism, Cross Section, Indirect Impact:Democracy . . . . . . . . . . . . . . . . . . 58

3.8 The Impact of a Free Press on Future Incidents of Terrorism, Cross Section, Indirect Impact:PR-CL _ . . . . . . . . . . . . . . . . . . . . 59

3.9 List of Countries . . . . . . . . . . . . . . . . . . . . . . . . . . 60

3.10 Summary Statistics . . . . . . . . . . . . . . . . . . 61

4.1 Cross Section Robust Regression: Impact of Financial Development on Urbanization Growth . . . . . . . . . . . . . . . . . . . . . . . . . . . 99

4.2 Cross Section Robust Regression: Impact of Financial Development on Urbanization Growth; including Financial Development Squared 100

$4.3 \quad 10$ Year Panel Robust Regression: Impact of Financial Development on Urbanization Growth . . . . . . . . . . . . . . . . . . . . . . . . . . 101

$4.4 \quad 10$ Year Panel Robust Regression: Impact of Financial Development on Urbanization Growth; including Financial Development Squared 102

4.510 Year Panel Robust Regression: Impact of Financial Development on Urbanization Growth; Using M2/M1 as proxy of FD . . . . . . . 103

4.6 List of Countries . . . . . . . . . . . . . . . . . . . . . . . . . . . . 104 
4.7 Summary Statistics . . . . . . . . . . . . . . . . . . 105 


\section{Chapter 1}

\section{Introduction}

Economists have been looking deeply into the importance of "institutions" in the process of economic development since the past five decades. The vast array of literature acknowledges unanimously that "institutions matter". If opening up of markets, removal of trade barriers or providing developmental assistance (among many other processes) would have been the only ways to put "poor" countries on the trajectory of growth and development, then why is it that the "poor" nations still thrive to develop and the extent of their success vary significantly across board?

It is very much therefore the fact that something else plays a crucial role in determining the varied outcome. This missing link is primarily the quality of institutions a nation has. A country with better institutions successfully reaps the benefits of development and grows more than one with a poor state of institutions. Institutions have been defined in many ways. Douglass North in his seminal work defined institutions to be the rule of the game. He defined institutions as the "humanly devised constraints that structure human interaction" that help reduce risk and uncertainty of human behavior. Institutions, thus defined, shape the incentive structure and hence productivity of an economy and reduce transaction costs

of doing business. He goes ahead to state that political and economic institutions happen to be the fundamental determinants of economic performance of a country. 
Researchers have established that countries with good institutions perform better while bad institutions ruin all. In this context it is also worth a mention that institutions can be broadly classified as formal and informal, though it is often difficult to distinguish between the two. While formal institutions (as discussed above) can be categorized as political and economic constitution, legal framework and the financial system, informal institutions are the norms, conventions and codes of conduct that finally ensure how much of formal institutions convert into practice. At this outset it can be mentioned that the essays in my dissertation clearly deal with various forms of formal institutions and their impact on different aspects of development of a nation.

It will be difficult to imagine an economy running without institutions. To minimize or alleviate uncertainty in the world we live in, establishing good institutions are the only way out. Efficient institutions are needed to protect property rights, to generate a favorable investment and economic climate, to minimize or curb corruption, to create good corporate governance practices, to mobilize allocation of savings and also to dissipate information among masses. There are various studies which have focused on the numerous aspects of the importance of institutions and the positive spillovers, thus, generated. The essays of my dissertation aim to take this research further and explore the role of financial institutions, political institutions and the role of a free media in the contexts of development. The first two essays of my dissertation reiterate the importance of a free media as an institution. The first essay elaborates on how foreign direct investment inflow into an economy can contribute towards the freedom of the institution of media. The second essay analyzes how a free press can help mitigate incidents of terrorism and strengthen a democracy for the same cause. The third essay looks into the impact of the development of financial intermediaries in affecting the pace of urbanization and urban concentration in various countries.

Chapter 2 titled "The Impact of Foreign Direct Investment on Press freedom" establishes FDI as a major determinant of media freedom. Using a panel of 115 countries over a period of 20 years, the results reveal that FDI is an absolute necessity for a free and efficient media. 
FDI in an economy strengthens all its institutions and the general socio-economic framework. Higher levels of FDI inflow within a country has its share of positive spill-over on the media sector as well, which is one of the most important and sensitive institutions. The spill-over effect works by removing information asymmetry, bringing financial independence, bestowing technological superiority, enhancing quality and reach and raising public awareness. These, in turn, pave the way for a free and potent media. The results of the study establish FDI inflow as an important contributor to media freedom. The higher the flow of FDI into an economy, the free-er and more efficient is the media.

Previous literature has established how a good institutional framework brings in more FDI in an economy. However, it may well be the case that FDI flows itself have important implications for the institutional framework of an economy. This is even more important given the positive impact free market institutions have on the growth of a nation, either directly through enhancing total factor productivity or indirectly by stimulating investment. The analysis investigates whether an increasing inflow of FDI into an economy can have a positive spillover on its media in the sense of making it free from government stronghold. To my knowledge, this is the first attempt to explore such causality, and thus is a significant contribution to the existing literature on media freedom and economic development.

Since media plays a significant role in affecting a nation's outlook, understanding of the FDI inflow-media freedom relation is of utmost importance. The paper bases its arguments on the premise that FDI brings in sufficient capital as well as the infrastructure for an efficient institutional framework. "Media" being an institution should thus be affected as well. A privately controlled media has been proved to be desirable for the welfare of an economy (Besley and Burgess (2002); Djankov et al. (2003); Coyne and Leeson (2005)). Presence of foreign capital spurs healthy competition in the society in general, including the media sector, and, thus, media quality is enriched. FDI brings with it new technology, economies of scale and global standards to look up to. It brings with it the capital to relieve the media sector from the stringent control of the government. This would bring 
financial comfort to the sector, giving it wings for expansion, experimentation and freedom from bias arising from any governmental financial obligation. Apart from this, presence of privatized and international media houses themselves generates healthy competition in the sector. This is because these private parties have an incentive to build reputation in the foreign land as that impacts their presence globally. Thus, the mere presence of private and foreign media would ensure a higher quality of broadcast and propagation of unbiased information. The argument is based on a similar study by Eichenberger and Frey (2002) where they investigate the inclusion of foreigners in supplying political services. Their study reveals that it not only raises the supply of candidates but also raises competition which eventually renders the domestic producers more efficient and credible. This is made possible because the performance of internationally active policy firms in a country determines their chance of winning in other countries. Hence, they have a bigger incentive to build up their reputation vis--vis traditional suppliers of politics. I explore the hypothesis using a panel of 115 countries for a period of 20 years. The sample includes high, middle and low income economies.

The hypothesis is tested using Ordinary Least square (OLS), Two-Stage Least square (2SLS) and Ordered Probit techniques. A 2SLS approach is undertaken to account for endogeneity issues between FDI and Press Freedom and Democracy and Press Freedom. The Ordered Probit technique is applied to encompass a larger sample period since the data on Press Freedom prior to 1994 is in qualitative form. For this the scores of Press Freedom is converted into three categories - Free, Partly Free and Not Free to take the study forward. The results support the hypothesis across various alternative specifications robustly.

While chapter 2 brings forth a determinant of a free press, Chapter 3 establishes the importance of the free press in the context of mitigating terrorism. Titled "Countering Terror: The Importance of a Free Press" the essay is an attempt to reestablish the importance of a free press in the context of combating the most dreadful threat faced by countries in current times - terrorism. Considering the case of transnational terrorism, the robust analysis 
presented above establishes that a free press does have a mitigating impact on terrorism. The importance of the paper extends further to substantiate that, though a democracy has often been criticized to be terror-inviting, when empowered by a free press, the two together have a strong terror dampening effect.

The analysis is two pronged. Firstly the paper attempts to see the influence of having a free press on future rate of terrorism. Secondly, it addresses how the same works in conjunction with a democratic institutional set-up. So, the paper hypothesizes that a free press will have a terror dampening effect. A free press, by disseminating information, directly raises general awareness amongst the populace. It not only showcases the impact of such incidents but also brings forth the root causes of the same. People become aware of the national and international conditions associated with such fatal incidents of terrorism. The free flow of information enables them to contextualize such incidents and make informed decisions and form opinions on that basis. With a free press in action the authorities also have less scope of fabricating or hiding information and this raises their accountability. This creates a healthy environment of checks and balances. With more awareness and pressure of accountability, the liability of the authorities to take attentive measures also rises, all of which contribute towards combating future incidences of terrorism to a great extent. Apart from this, a free press indirectly helps combat terrorism by empowering and enabling a democracy.

The analysis considers a sample of 121 developed and developing countries for a period from 1995-2004. The paper considers both panel and cross-section analysis to test the hypothesis. The analysis is robust not only to alternate specification and both panel and cross sectional analysis, but also to the use of alternative control variables. The strength of the analysis also lies in the fact that not only is it tested for widely used composite proxies of democracy, but is also been tested on proxies capturing various other aspects of democracy and the claim remains robust throughout.

The study is not only important as it upholds the importance of having a free press and 
a sound democracy, but also establishes how important it is to empower a democracy with a free press and this definitely has sound policy implications. This is especially for countries weaker on either front as also for all countries plagued by threats or actual incidents of terrorism. It also refutes the doubt that lurked about the role of a free press in dealing with the 26/11 terror incident in India. Considering the detailed analysis, it can be safely claimed that the free press definitely has a negative impact on future occurrences of terrorist incidents.

In Chapter 4 "Counting on Financial Development for Urbanization" we examine the extent to which the level of a country's financial development plays a contributory role in determining the pace of urbanization and urban concentration in different countries. We hypothesize that the more developed the financial sector will be, the lower will the growth of urbanization and urban concentration. Our argument is based on the premise that a developed financial intermediary sector reduces transaction costs, facilitates trading, and allows economic agents to diversify risks. This eases out locational constraints enabling individuals to decentralize their activities.

Using a sample of developed and developing countries over the period 1975 - 2005, the paper shows that a higher level of financial development is associated with a lower growth in urbanization and urban concentration. The empirical analysis also concludes that the latter result is mostly driven by the experience observed in developing countries.

Rapid urbanization in most developing countries in the past half century has been characterized by excessively high levels of concentration of the urban population in very large cities. Such large urban concentrations in developing economies are characterized by poor quality of life, health hazards and degrading environmental concerns. Urbanization is indispensible for the industrialization of a country, which in turn is needed for putting it on a trajectory of growth and development. However, too much or too rapid urbanization is not desirable. Some degree of urbanization initially reduces transaction costs and inter- and intra-regional expenditures. But unplanned and fast paced urbanization is associated with externalities 
such as congestion, pollution, overpopulation, etc. As the banking sector develops, especially in developing in economies, economics agents will find it easier to carry out their economic functions with less dependence from the city center.

The importance of the analysis not only lies in the fact that this is the first attempt to empirically assess the effect of a developed financial intermediary sector on the rate of urbanization or urban concentration. It is also the first attempt at a cross country analysis in this regard. Further, the study has important policy implications as it proves that when the financial intermediation develops, it triggers urban decongestion and enables proper urban development, especially in developing countries. 


\section{Chapter 2}

\section{The Impact of Foreign Direct Investment on Press Freedom}

\section{INTRODUCTION}

Almost all countries today realize the importance of foreign direct investment (FDI) for economic development. FDI has been one of the major contributors in globalizing the economy. According to an IMF report, while FDI has increased by an average of 13 percent a year during 1990-97, it increased by an average of nearly 50 percent a year during 1998-2000. FDI flows can have considerable impacts on the overall shaping of an economy. As a nation becomes more integrated with the world economy, there is a huge impact on the GDP growth rate, economic policies adopted and, most importantly, the overall institutional framework. The important benefits of FDI, as cited in the literature, is that it generates externalities in the form of technology transfers, creates spillover effects of knowledge and also adds to the capital stock of an economy.

Previous literature has explored the relationship between FDI and growth. The conclusions are conflicting. While one set of researchers support a positive relationship between FDI and growth (Bosworth et al. (1999); Lipsey and Sjholm (2004)), others find that the re- 
lationship is ambiguous (Lipsey (2000)). However, a major strand of the literature seems to agree that in the presence of sound financial institutions, greater trade openness and greater human capital, FDI exerts a positive impact on growth (Balasubramanyam et al. (1996); Alfaro et al. (2003); Hermes and Lensink (2003)). All these findings stress the impact FDI has on the host country. Another strand of literature has concentrated on the determinants of FDI flows and what kind of institutional framework is desirable for a nation to attract greater FDI flows. Yet, the FDI flows itself may have important implications for the institutional framework of an economy. This is even more important given the positive impact free market institutions have on the growth of a nation, either directly through enhancing total factor productivity or indirectly by stimulating investment (Dawson (1998)).

We therefore deviate from the existing literature concentrating on FDI-growth linkage and determinants of FDI per se, and focus on the positive spillover of FDI on a country's institutional framework. We choose to concentrate on a particular institution, namely the media sector, in this regard. FDI inflows into a country, in general, can have considerable positive spillovers on the media sector. Media - in all its form namely print, internet, television and advertisements plays an indispensable role in informing and shaping the mindset of an economy, be it at the local or the national level. It goes beyond being merely "cultural" and is infact an "institution" which, perhaps, has the largest immediate effect on the population at large. The indispensability of media is largely owing to its capacity to reach people at every corner of the society. Hence it bears the brunt of channelizing information, biased or otherwise to the beneficiaries. It has the sole potential to make the government and businesses accountable and enable the populace to make more informed decisions.

The past decade has seen this industry as the fastest growing around the world, with globalization catalyzing its pace. Since media plays a significant role in affecting an entire nation's outlook, understanding of the FDI inflow-media freedom relation is of utmost importance. With no previous studies of the relationship between FDI and media, our research makes a significant contribution in this regard. We base our arguments on the premise that 
FDI brings in sufficient capital and also the infrastructure for an efficient institutional framework. "Media" being an institution should thus be affected as well. A privately controlled media has been proved to be desirable for the welfare of an economy (Besley and Burgess (2002); Djankov et al. (2003); Coyne and Leeson (2005)). Presence of foreign capital spurs healthy competition in the society in general, including the media sector, and, thus, media quality is enriched. FDI brings with it new technology, economies of scale and global standards to look up to. It brings with it the capital to relieve the media sector from the stringent control of the government. This would bring financial comfort to the sector, giving it wings for expansion, experimentation and freedom from bias arising from any governmental financial obligation. Apart from this, presence of a privatized and international media houses itself generates healthy competition in the sector. This is because these private parties have an incentive to build reputation in the foreign land as that impacts their presence globally. Thus, the mere presence of private and foreign media would ensure a higher quality of broadcast and propagation of unbiased information. Our argument is based on a similar study by (Eichenberger and Frey (2002)) where they investigate the inclusion of foreigners in supplying political services. Their study reveals that it not only raises the supply of candidates but also raises competition which eventually renders the domestic producers more efficient and credible. This is made possible because the performance of internationally active policy firms in a country determines their chance of winning in other countries. Hence, they have a higher incentive to build up their reputation vis--vis traditional suppliers of politics.

We explore our hypothesis using a panel of 115 countries for a period of 20 years. The sample includes high, middle and low income economies. The results reveal that greater FDI flows to an economy lead to higher levels of press freedom. The conclusions distinctly stress the need for privatization in the media industry. We confirm the findings that state's control over the media sector is detrimental from the development perspective. Our results are robust with both ordinary least squares (OLS) and ordered probit specifications. Further, we run 2SLS specifications to control for endogeneity in the specifications. The conclusions 
remain unchanged. The results are, further, robust to the addition of control variables and alternate specifications.

Section 2 discusses the impacts of FDI on the development of the host countries. Additionally, it also charts out the impact of FDI inflows on one of the most sensitive institutions, the media sector. Section 3 discusses the dataset used in the paper and its sources. Section 4 describes the benchmark results using an OLS specification. It also justifies the rationale for using 2SLS specification. Section 5 presents the Ordered Probit specification and the results. Further, it also discusses the 2SLS results. Section 6 discusses some robustness issues. Section 7 concludes.

\section{THE ROLE OF FOREIGN DIRECT INVESTMENT}

A concrete definition of foreign direct investment is 'the existence of a long-term relationship between the direct investor and the enterprise and a significant degree of influence by the direct investor and the enterprise'. Although multinational firms are the most significant sources of foreign direct investments (FDI), a direct investor can also be an individual, a firm or a government. During recent times, lesser restrictions on capital movements across the world have increased the importance of foreign direct investment for the developing world. The importance of FDI for economic development and modernization are being realized more and more by the developing countries, emerging countries and countries in transition. Statistics reveal that FDI flows have increased by four or five times from 1995 to 2000 amounting to an astronomical figure of 1.3 trillion US dollars. According to United Nations Conference on Trade and Development (UNCTAD), 'the use of locational incentives to attract FDI has considerably expanded in frequency and value.' During financial crisis period of many economies, FDI flows have recovered back quickly from the depression unlike private capital flows like portfolio and debt flows (Dadush et al. (2000); Lipsey (2001)). Thus, these might provide developing countries with enough incentives to prefer FDI over 
other sources of private capital.

Free flow of capital is largely favored by economists due to the higher rate of return it seeks. Foreign Direct Investment, either as Greenfield investments or Mergers and Acquisitions, form a major part of this. As noted by (Feldstein (2000)), unrestricted capitals flows have several advantages like reduction of risk faced by owners of capital through diversification opportunities of lending and investment, spread of best practices in corporate governance, accounting rules and legal traditions and restricting bad policy practices by the government through global mobility of capital. Apart from the above, there exists an extensive literature that points towards various other benefits that host countries derive from FDI.

FDI contributes to growth in host countries through various channels. It allows the transfer of technology, particularly in the form of new varieties of capital inputs that cannot be achieved through financial investments or trade in goods and services. According to most empirical research, FDI flows accelerate factor productivity and bring about income growth for economies much more than the capacity of domestic investment. Since the firms bring with them superior technology, there is quality enhancement for the goods produced as well as rise in the volume (Lipsey and Sjholm (2004)). A comprehensive study by (Bosworth et al. (1999) ) provides evidence on the effect of capital inflows on domestic investment for 58 developing countries during 1978-95. The authors distinguish among three types of inflows: FDI, portfolio investment, and other financial flows (primarily bank loans). While an increase of a dollar in capital inflows is associated with an increase in domestic investment of about 50 cents, FDI appears to bring about a one-for-one increase in domestic investment. They conclude that the benefits of FDI, thus, are sufficient enough to offset the evident risk of allowing markets to freely allocate capital across borders of developing countries.

The rise in the income levels of the host country is caused by addition to the capital stock. Studies have shown that FDI flows into Canada have led to increased capital formation $(\overline{\text { Lipsey }}(2000))$. Lipsey $(2000)$ did not find any significant impact on capital formation 
for other countries. Other evidences ruled out the possibility that FDI improves growth by helping in capital formation (Borensztein et al. (1998)). They confirm that FDI is instrumental to economic growth by means of stimulating technological progress. They found a positive impact of FDI on growth through technology spillover that is labor augmenting or Harrod-neutral. Technological progress leads to knowledge spillovers which can be through the channels of imitation, competition, linkages and/or training (Lensink and Morrissey (2001); Barry et al. (2004), (Hermes and Lensink, 2003)). Borensztein et al. (1998) proved that the presence of a threshold level of educated labor force is needed in recipient countries for FDI to have a positive impact on growth. Hermes and Lensink (2003) confirmed this finding using a panel of 67 LDCs. They also came up with evidence that the development of the domestic financial system is a necessary condition for FDI to generate positive externalities that increase output.

The impacts of FDI on trade, i.e. exports and imports, are ambiguous. A horizontal FDI, for instance, theoretically induces a decrease in the host country's imports and, ceteris paribus, an improvement of its trade balance. This prediction may not hold true if the inputs used by the foreign-owned firm are imported from abroad. Furthermore, a FDI consisting of selling in the host country goods manufactured abroad, that is, a vertical integration forward will have the effect of increasing the home country's imports. MNCs are also capable of setting up their own corporate governance systems in the sense of imposing new company policies, internal reporting systems and rules about information disclosures and employment of foreign managers. This may boost corporate efficiency.

There exists a dearth of literature on the impact of FDI inflow on media freedom. Previous research has proved that state control suffer from poverty, high infant mortality rates, higher corruption and less developed capital markets (Djankov et al. (2003)). Further, for a state controlled media, politicians get an additional edge in manipulating information reaching the public and serving their private interests at the expense of the society Coyne and Leeson (2005)). Besley and Burgess $(2002)$ consider the case of India, a well established 
federal democracy with a relatively free media, to establish how a free press can affect the political economy of responsiveness. India embarked on its process of liberalization in the 1990s. Since this period, the country has seen an increasing inflow of FDI into various sectors of the economy. Post 1990s, the media sector has also seen the entry of a plethora of private channels in the broadcasting sector. They turned news into an essential commodity. Their vastly improved quality, quantity and variety have given the freedom of choice to the various section of the population. It is reasonable to assume that following the past trend, continued inflows of FDI into the Indian economy will bring, further, freedom to the media sector.

It is expected that greater FDI flows will eventually bring forth financial comfort to the sector and take a step forward to "free" it. A competitive, free media, both print and electronic, will be more transparent in its activities and will posses enriched economic and functional environment. In the presence of abundant private capital, the media outlets need not depend on funds from the government for their functioning. This enables them not to become a spokesperson for the government and frees them from the burden of circulating biased and manipulated information. Mehfuz (2002) mentions that with the advent of privatization of electronic media in Bangladesh, the media houses have ceased to be mere extensions of the 'government's propaganda mechanism' and are thinking freely. In Bangladesh, today most of the leading newspapers derive $70-90 \%$ of their advertising revenue from the private sector.

Alongside the provision of direct control as mentioned above, government also can have a stronghold through indirect hold on media through ownership of vital infrastructural and distributional facilities of a privately owned media-outlet. Coyne and Leeson (2008) gives extensive examples from Romania and Vietnam where various privately owned media-outlets were dependent on the state for infrastructure and distribution network and hence generated biased opinions. Kassem (2002) points out that the Egyptian press is a prominent stronghold of the government and is prime target for corruption. 'Since the region is ruled either by monarchies or military dictatorships that have huge budgets they can use to embellish their 
image in the media.' A significantly high (to the proportion of 90\%) of the previously "independent" press was backed by one or more of the above-mentioned regimes. This led to replacement of sales and marketing managers to be replaced by 'pushy publishers' trying to impress the regimes' embassies. Furthermore, the distribution figures of these publications were also never audited and this destroyed competition. In situations like this FDI can provide for the infrastructure and distributional facilities. From our data and Fig (2.3) it is evident that, since 1990 FDI flows to Egypt have decreased, and the status of media freedom has degraded from 'partly free' ' to 'not free'. Foreign capital brings with it new and innovative technical know-how which is capable of changing the face of media infrastructure. The superior technology would ensure trained efficient journalists, willing to take up the risk of covering any political event. This would lead to the spread of unbiased information in the society and contribute towards a healthy political environment. Further, the enhanced technology will ensure rich content, unbiased viewpoint and good journalistic ethics.

Since FDI flows can ensure better corporate governance, efficient laws and criterions will be enforced. This will definitely generate better legal environment leading to greater media freedom. Journalists will be able to operate freely and government will have less power to curb media operations For example, the media freedom of Zimbabwe is paralyzed by domineering laws like LOMA and Public Order and Security Act. These violate freedom of expression in the country (Chavunduka (2002)). As documented by him, they faced the first of the several instances of journalist harassments in the country. Most importantly, Zimbabwe has a history of low FDI inflows (see Fig 2.3).

\section{THE DATA}

The data for the study has been taken from various sources. Media freedom data is proxied by the Freedom House Index. Freedom House's survey data, spanning over a large time frame, is the most comprehensive dataset available on global media freedom. The level

\footnotetext{
${ }^{1}$ Free, Partly Free and Not Free are the press freedom scores categorized qualitatively by Freedom House.
} 
of press freedom in each country is based on twenty three methodology questions divided into three categories: the legal environment, the economic environment and the political environment. The legal environment category judges laws and criterions that could influence media contents, the ability of journalists' to operate freely and the government's use of regulations to curb media operations. The degree of political control over the content of news media forms the basis for the political environment. The economic environment includes the structure of media ownership, transparency and concentration of ownership and the impact of corruption and economic institutions on media. The press freedom score ranges between 0 and 100 points. The Freedom House index has assigned higher points to lower levels of press freedom. For the convenience of analysis, the scores have been rescaled so that higher scores denote more free environment.

The data on FDI is taken from United Nations Conference on Trade and Development (UNCTAD) database. The measure considered is FDI inflows to a country as a percentage of GDP. Since data is available 1984 onwards, the sample period considered is 1984 to 2003. Several explanatory variables are used besides FDI over GDP. To control for openness, we use trade as percentage of GDP as one of the controls. Since FDI over GDP and trade over GDP are correlated, we have taken care of the possible biasness in the estimates by running two stage least squares later. Following Djankov et al. (2003) and Egorov et al. (2007), we use GDP per capita as one of the major determinants of press freedom. GDP per capita is used as an indicator of economic well being of an economy. Population can also be a major determinant of press freedom of an economy. Since we use per capita figures for both GDP and FDI, it allows us to take the relative country size into account and, hence, we exclude population as one of the controls. We, instead, use population as one of the instruments in the 2SLS specifications. Further, we use primary years of schooling as another control. It is used as a proxy for the level of education of the population ${ }^{2}$ A higher level of education raises the general awareness of the population. This is in accordance with the theory

\footnotetext{
$\sqrt[2]{\text { Nieswiadomy and Strazicich }(2004)}$ have shown that education is strongly related to the level of political freedom of an economy.
} 
that a free media is strongly related to the demand of the public (Egorov et al., 2007). Further, Democracy has been used from the Polity IV dataset as a proxy for institutions. Research has shown that political institutions of an economy has important implications for its press freedom (Djankov et al. (2003); Egorov et al. (2007)). The variable ranges from 0 to 10 with higher values representing more democratic institutions. Periods of interruption, interregnum and transition are assigned scores of $-66,-77$ and -88 respectively. Such values are excluded from the dataset. We also control for natural resource dependence in our regressions. Egorov et al. (2007) argues that the chances of having a free press in a resource rich country are low since the ruler has incentives to exploit the rents generated and curb information flows. The share of natural resource exports to GDP in 1980 is used as a proxy for natural resource dependence. Natural Resource exports are defined as the sum of exports of primary agriculture, fuels and minerals. The data is taken from Sachs and Warner (1997) paper. Finally, regional dummy variables have been used as additional regressors so that the estimates are not over or under estimated by regional characteristics. The regional dummy variables considered are Middle East and North Africa (MEN), South East Asia (SAR), East Asia and Pacific (EAP), Europe and Central Asia (EAC), Sub-Saharan Africa (SSA) and Latin America and the Caribbean (LAC). A pooled OLS approach for 115 countries over the sample period 1984 to 2003 is used. We control for time effects in our specifications. Further, we check for robustness of the results by controlling for specific effects. We control for corruption, infrastructure and technology in the specifications. Corruption is taken from ICRG dataset while the rest are from the WDI database. The list of countries used in the paper is provided in Table (2.4). A detailed description of the variables used in the paper is provided in Table (2.5). 


\section{THE EMPIRICAL CONNECTION}

Since the press freedom scores are available as quantitative data from 1994 onwards, our sample period for ordinary least squares (OLS) is from 1994 to 2003. The dependent variable is the rescaled press freedom score for which higher values indicate a more free press. All the variables, except democracy and schooling are standardized in terms of GDP per capita figures. Controlling for time effects helps to control for the presence of autocorrelation in the data to some extent. The regression specification is as follows

$$
P F_{i t}=\alpha_{0}+\beta_{1} F D I_{i t}+\beta_{2} X_{i t}+\beta_{3} R E G I O N A L_{i}+Z_{t}+\varepsilon_{i t}
$$

where $P F_{i t}$ denotes the press freedom level for country $i$ in period $t, F D I_{i t}$ represents the net inflow of Foreign Direct Investment as a percentage of GDP to country $i$ in period $t, X$ is a vector of covariates containing the set of control variables, REGIONAL represents the vector of regional dummies and $Z_{t}$ represents the vector of year dummies. The set of control variables include Gross Domestic Production (GDP) per capita, trade openness, schooling, resource abundance and the proxy for political institutions, democracy ${ }^{3}$ Column (1) of Table (2.1) presents the results of the OLS regression. The results suggest that greater FDI flows lead to a more free press. The coefficient is positive and significant at the $1 \%$ level. The value of the coefficient suggests that a unit rise in FDI over GDP leads to a significant increase in the value of press freedom. To express in figures, a 10 percentage point rise in FDI leads to a 4.4 unit (or a 7.5 percentage point) rise in the extent of media freedom. This is suggestive of the greater need of FDI in the media industry. GDP per capita is positive and significant at the $1 \%$ level signifying that an increase in the level of GDP per capita leads to an improvement in the press freedom situation. Resource abundance is negatively related with press freedom but the coefficient is insignificant. Theory suggests that more resource rich countries have poor institutions and hence are prone to having more state controlled

\footnotetext{
${ }^{3}$ The results remain unaffected when GDP growth is included as an additional control in both OLS and OProbit specifications.
} 
press. Thus, greater resource abundance should lead to lower press freedom levels and this is what the result confirms. As expected, schooling is positive and significantly related with press freedom. Political institution has a positive and significant impact on press freedom signifying that better institutional quality would be associated with more free press. Trade as percentage of GDP has a positive and significant impact on press freedom indicating that greater openness leads to a more free press. All the regional dummies, except LAC, are significantly related with press freedom. The year dummies are insignificant. They are not reported in Table (2.1). The $\mathrm{R}$ square is 0.8 which suggests that the explanatory variables explain $80 \%$ of the variation in the dependant variable. Figure 2.1 shows the scatter plot of FDI and press freedom. The positive slope of the trend line confirms our findings. Further, we plot the association for the periods 1994, 1999 and 2003 separately. The association is clearly positive for all the diagrams

There can be potential problems of endogeneity in the model. The main variable of interest, FDI over GDP, can be endogenous and, hence, a simple OLS would lead to biased estimates. Domestic capitalists may block FDI flows for an economy to have control over the press. This is evident from incidents in countries like India. Recently, government imposed restrictions on levels of FDI which are allowed in print or broadcast. Thus, the extent of press freedom can actually be a determinant of FDI flows into an economy.

To resolve the endogeneity problem, we run two stage least squares (2SLS) ${ }^{5}$ We use exchange rate, population and financial development as the instruments for FDI over GDP. The measure used for financial development is the ratio of private credit by deposit money bank to GDP. In the first stage, FDI over GDP is regressed on the exogenous instrument and set of variables which also affect press freedom. These variables are democracy, schooling, natural resource abundance, GDP per capita, and the set of regional and year dummies. Trade over GDP is excluded due to the inherent correlation between trade and exchange

\footnotetext{
${ }^{4}$ We have not excluded the outliers from the scatter plots. The exclusion of the outliers will strengthen the association for the different diagrams.

${ }^{5} \mathrm{Wu}$-Hausman test confirms the need for 2SLS. The small $\mathrm{p}$ value of the test suggests that OLS is inconsistent and that 2SLS is appropriate.
} 
rate. To test the quality of the instruments, we have run the Sargan and the Basmann's tests of overidentifying restrictions. These are tests of the joint null hypothesis that the excluded instruments are valid instruments, i.e., uncorrelated with the error term and correctly excluded from the estimated equation. We fail to reject the null due to the high $\mathrm{p}$ values (p $=0.53$ for Sargan's test; $\mathrm{p}=0.53$ for Basmann's test) $)^{6}$

Further, the choice of our instruments in running 2SLS has followed the methods propounded by the studies of Murray (2006) $)^{7}$ and Levitt (2002). The 2SLS specification is as follows

$$
\begin{gathered}
F D I_{i t}=\beta_{0}+\beta_{1} \text { ExchangeRate }_{i t}+\beta_{2} \text { Population }_{i t}+\beta_{3} \text { FinancialDevelopment }_{i t}+\beta_{4} W_{i t}+\delta_{i t} \\
P F_{i t}=\beta_{0}+\beta_{1} F \tilde{D} I_{i t}+\beta_{2} X_{i t}+\beta_{3} \text { REGIONAL } L_{i}+Z_{t}+\varepsilon_{i t}
\end{gathered}
$$

Equation 2.2 represents the first stage of our 2SLS specification. FDI or Foreign Direct Investment is the regressand. The instruments are exchange rate, population and financial development while $\mathrm{W}$ contains the set of variables which also affect press freedom in equation 3, including the regional and time dummies. Equation 2.3 represents the specification of the second stage. $F \tilde{D} I_{i t}$ denotes the instrumented FDI. The second stage regression results are presented in Column (1) of Table (2.2). The results show that FDI has a positive and significant impact on press freedom even after controlling for time and regional effects. The coefficient is significant at the $1 \%$ level and signifies that a 10 percentage point increase in FDI leads to a 14.9 unit rise in press freedom. Democracy, GDP per capita and Schooling

\footnotetext{
${ }^{6}$ The $\mathrm{F}$ test for excluded instruments is high $(\mathrm{F}(3,842=27.0))$ and above usual threshold implying that the instruments are relevant.

${ }^{7}$ Following those studies we have used alternative sets of instruments which have kept our results unchanged and robust. As an alternative set of instruments, we use exchange rate, population and another proxy of financial development namely the ratio of private credit by deposit money banks and other financial institutions over GDP. Further we ran reduced form regressions by taking the instruments as explanatory variables and the troublesome explanator as the dependent variables. Our results show that the coefficients are significantly different from zero and have the desired signs, thus proving the credibility of the instruments. For example, according to the established argument and intuition, exchange rate bears a negative relation with FDI.
} 
have a positive and significant effect on press freedom. Resource abundance has a negative impact on press freedom but it is not significant. All the regional dummies are significant. The year dummies remain mostly insignificant.

Democracy may also have reverse causality problems with press freedom (Egorov et al. (2007)). More democratic countries may be associated with more free press but it is also possible that press freedom makes a country more democratic instead. To correct for this endogeneity issue, we run a 2SLS specification by instrumentalizing both FDI and democracy with the same set of instruments as before. We revalidate our choice of instruments with the same set of tests and our choice is confirmed yet again. In fact, the p values for overidentifying restrictions are higher this time $(\mathrm{p}=0.90$ for Sargan's test; $\mathrm{p}=0.90$ for Basmann's test).

Column (2) of Table (2.2) presents the 2SLS results when both the variables are instrumentalized. The coefficient of FDI is positive and significant at the 5\% level. GDP per capita and Democracy still have a positive and significant impact on press freedom but the schooling variable loses its significance. Resource abundance becomes positive but is highly insignificant. Some of the regional dummies are significant 8

\section{ORDERED PROBIT SPECIFICATION}

The press freedom scores from Freedom House are available as quantitative data from 1994 onwards. Prior to 1994, the status of the press freedom of an economy is stated as 'Free', 'Partly Free' and 'Not Free'. Thus, due to data constraints, we cannot check our results over a larger sample period by a simple OLS approach. An alternative approach would be to adopt an ordered-response model which is characterized by the indexed nature of the outcome variable. The dependant variable is latent but a continuous descriptor of the response. We adopt a particular type of ordered-response model, the ordered probit model. Ordered probit is the appropriate model when the responses are ordinal and not numerical.

\footnotetext{
${ }^{8}$ To confirm our findings, we re-run the regressions by using exchange rate, population and alternative measure of financial development as instruments. The results remain robust.
} 
For our model, the limited dependent variable is a dummy for press freedom. The dummy takes three values, 0 for a not free status, 1 for a partly free status and 2 for free status. Thus, the variable is ordinal in nature. In such a model, it is assumed that the random errors are distributed normally. The implicit assumption of the model is that the differences of the occurrences of free and partly free may not be the same as that of partly free and free. The regression specification is as follows

$$
\text { PressDummy }_{i t}=\beta_{0}+\beta_{1} F D I_{i t}+\beta_{2} X_{i t}+\beta_{(3) R E G I O N A L_{i t}+Z_{t}+\theta_{i t}}
$$

where PressDummy represents the dependant variable which is ordinal in nature. The rest of the variable notations are same as equation (2.1). Column (2) of Table (2.1) presents the results of the ordered probit regression. As evident from the table, the coefficient of FDI is positive and significant suggesting that greater FDI flows increases the probability of having a free press. Trade as percentage of GDP is significant at the 1\% level. GDP per capita, democracy and schooling have significant impacts on press freedom. Unlike the OLS specification, some of the year dummies become significant for the probit specification. Other then SA, the other regional dummies are significant. The likelihood ratio test statistic is the test of overall significance of the explanatory variables. The small "p" value is suggestive of the overall strong significance.

For a linear regression, the dependant variable is expected to change in response to a one unit change in the explanatory variable. To interpret the impact of FDI on press freedom we need to calculate the marginal effects. Marginal effects are calculated for each category of the dependant dummy variable, 'free', 'partly free' and 'not free'. The figures reveal that a one unit increase in FDI raises the probability of having a 'free press' by 1 percentage points. On the other hand, a one unit increase in FDI lowers the probability of having a 'not free' press by 1 percentage points. Thus, greater FDI flows always help towards the enhancement of press freedom levels. In Figure 2.3 and 2.4, we plot the association between FDI and 
media freedom over the time period. The press dummy is represented on the primary y-axis. The primary y-axis represents the press freedom score, 2,1 or 0 , for a particular year. The secondary y-axis represents the FDI inflows over the years. For example, as FDI inflows decrease from 1994 onwards for Egypt, press freedom degraded from 'partly free' to 'not free'. Cameroon has a low history of FDI inflows and, thus, the press freedom has retained the 'not free' status over the entire period.

As evident from the OLS specification, there will be potential endogeneity problems in the ordered probit specification as well. To treat the endogeneity problem, we run a 2SLS ordered probit specification. We use the same instruments as used before ${ }^{9}$ hamely population, exchange rate and financial development. In the first stage, FDI is regressed on the exogenous instruments and a set of variables which also affect press freedom. The second stage results are represented in column (3) of Table (2.2). The conclusion remains unchanged with the alternate specification. The coefficient of FDI as percentage of GDP is positive and significant at the $1 \%$ level. The low "p" value of the likelihood ratio test statistic is suggestive of the overall strong significance. GDP loses its significance but resource abundance now has a strong impact on the press freedom dummy. The marginal effects confirm the conclusions. Further, we run a 2SLS specification by instrumenting both FDI and Democracy. The results are presented in Column (4) of Table (2.2). The results are robust to the findings. FDI over GDP is positive and significant at the $5 \%$ level ${ }^{10}$

\footnotetext{
${ }^{9}$ As robustness checks we re-run the specifications with exchange rate, population and alternative proxy of financial development. The results are robust.

${ }^{10}$ To confirm that the estimates are not biased downwards several alternative estimation techniques have been adopted and the results remain consistent and robust in all. However, to formally take into account if there is measurement error in the model the method suggested by Kmenta (1997) is used. The Kmenta model is estimated by using various precision estimators: $0.99,0.97,0.95$ and 0.85 . The coefficient estimates and their standard errors are nearly unchanged by this alternative specification and hence establishes the robustness of the models.
} 


\section{ROBUSTNESS}

We run more regressions to ensure the robustness of our findings. We consider the same FDI measure but from a different database. The alternative measure is net FDI flows as percentage of GDP from the WDI statistics. We run both OLS and ordered probit with the alternative measure. The results are presented in Table (2.3). Column (1) presents the results with OLS specification while column (2) presents the results with the ordered probit specification. As evident from the Column (1), FDI is positive and significant at the $10 \%$ level. Trade, Schooling, Democracy and GDP have significant impacts on press freedom levels. The results of the ordered probit specification are presented in Column (2) of Table (2.3). The coefficient of FDI is positive but not significant ${ }^{11}$

We use an alternative measure by controlling for the total years of schooling instead of average years of schooling. The measure is taken from Barro and Lee (2000) dataset. The results are robust to the inclusion of the alternative measure for both OLS and the probit specification. Further, we strengthen our findings by controlling for corruption in the specifications. A higher level of corruption should be associated with poor institutional quality and, thus, lower levels of press freedom. The data on corruption is taken from International Country Risk Guide (ICRG) dataset. Corruption variable is rescaled so that higher values denote higher levels of corruption. The results are checked for both the smaller (OLS) and the extended (Oprobit) sample. The results are robust to our findings. FDI remains positive and significant at the $1 \%$ level for OLS but it insignificant for the ordered probit specification. Corruption is negatively related with press freedom for OLS suggesting that a higher level of corruption degrades the press freedom levels.

Egorov et al. (2007) control for internet penetration in their specification based on the argument that greater technological improvement should lead to greater levels of press freedom. We check our results by controlling for both infrastructure and technological improvement

\footnotetext{
${ }^{11}$ The results are robust with 2 SLS specifications. We check with alternative sets of instruments. The results are robust with the expanded dataset.
} 
in our specification. The proxy used for infrastructure is number of telephone mainlines per 1000 population. The results are robust to the inclusion of the variable. FDI remains significant for the OLS specification but becomes insignificant for Ordered Probit. Infrastructure is positive and significant in Oprobit specification, but not in OLS. The results are, qualitatively, similar when we control for number of television sets per 1000 people and internet penetration.

We also check our results by running cross country regressions. The OLS regression confirms the finding that greater FDI inflows are beneficial for the extent of press freedom of an economy. The FDI coefficient is positive and significant at the $5 \%$ level. Further, we check for convergence effects in our model. The results are run with cross country regressions but with change in the values of press freedom as the dependant variable. The dependent variable is the press freedom level of 1994 subtracted from the press freedom level of 2003. Each country has a single observation for every variable and the independent variable consists of the average values of the variables. The findings do not change our conclusion. The coefficient of FDI is positive and significant showing that higher levels of FDI leads to positive changes in press freedom levels. Further, we run our specification by controlling for both the levels and changes in FDI. It can be possible that the changes in FDI flows over the years matter more than the levels. The change in FDI considered is the FDI flow in 1994 subtracted from the FDI flow in 2003. FDI average remains positive and significant while the change is positive but not significant. This suggests that the levels of FDI matters more for changes in press freedom levels rather than changes in the flows of FDI.

\section{CONCLUSION}

In this paper we establish that higher inflow of FDI to an economy has a positive spillover effect on its media sector. It significantly enhances media freedom. FDI in an economy 
strengthens all its institutions and the general socio-economic framework. The higher level of FDI inflow within a country has its share of impact on media sector as well, which is one of the most important and sensitive institutions. The positive spill-over effect works by removing information asymmetry, bringing financial independence, bestowing technological superiority, enhancing quality and reach and raising public awareness. These, in turn, pave the way for a free and potent media. The results establish FDI inflow as an important contributor to media freedom. The higher the flow of FDI into an economy, the free-er and more efficient is the media. Numerically, a 10 percentage point increase in FDI inflows leads to 4.4 unit rise in press freedom. The results are robust to both OLS and ordered probit specifications. Further, to control for endogeneity in the data, we run 2SLS specifications and the conclusions remain unchanged. The results also remain robust with the inclusion of control variables and alternate specifications.

The argument however could be better established if data on FDI inflow into the mediasector itself could be known for economies across the world. Our future research endeavor definitely wants to take that into account but is sadly dependent on data availability. Future research in this area wold definitely try to fill this gap. Further, in future it will be interesting to investigate if the impact of FDI on the quality of media is contingent on the condition of political institution in the same. This too, is therefore a potential future research agenda. 
Figure 2.1: The Association between Foreign Direct Investment Inflows and Press Freedom (Whole Sample))

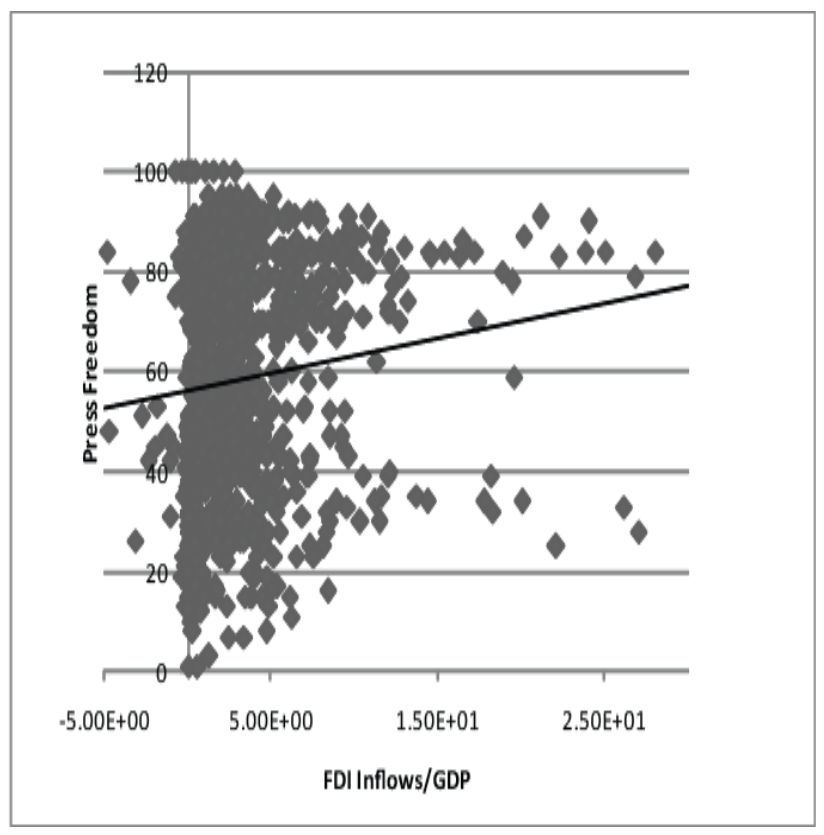


Figure 2.2: The Association between Foreign Direct Investment Inflows and Press Freedom (Specific Years))
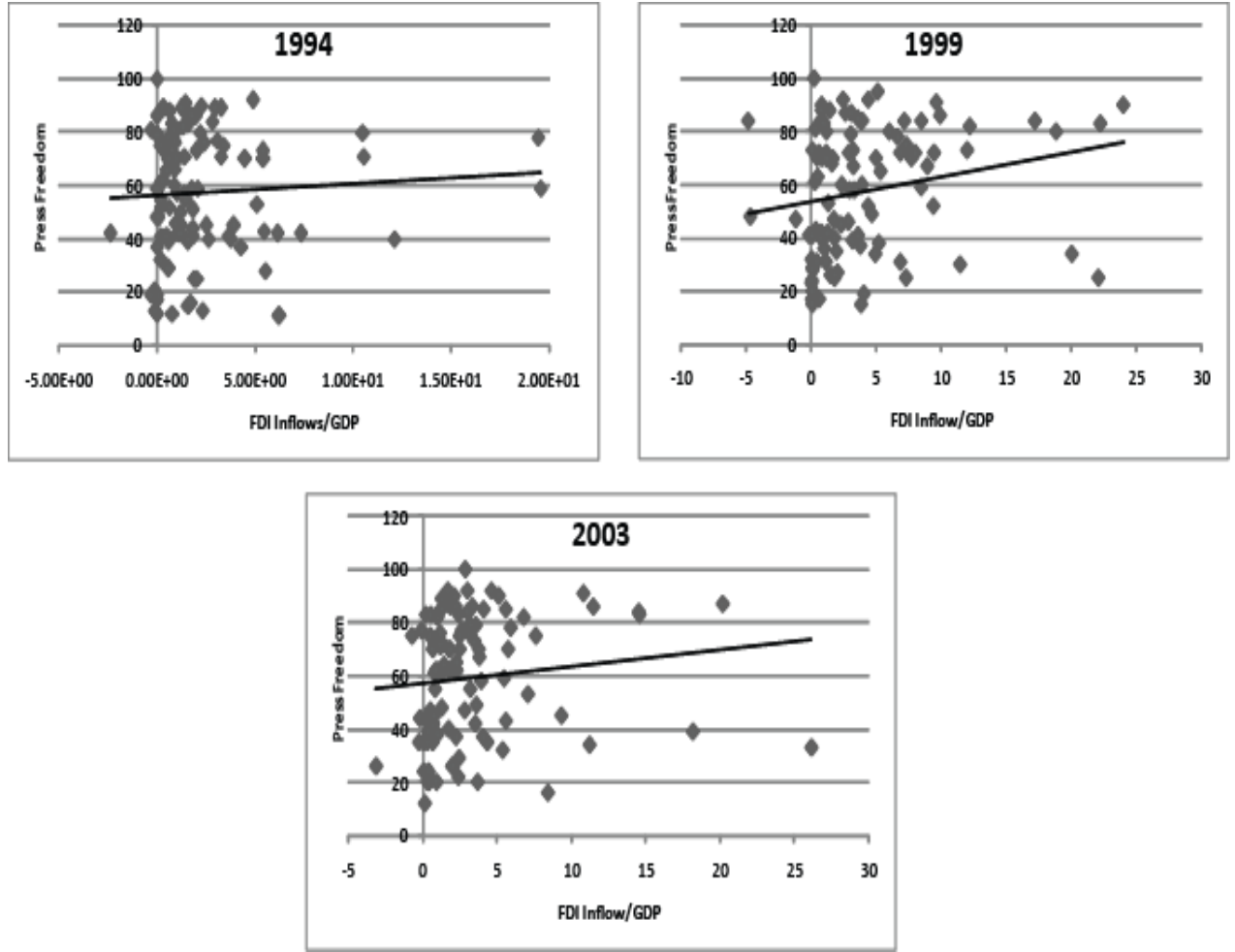
Figure 2.3: The Association between FDI and Press Freedom; Note: $0=$ 'Not Free'; 1 = 'Partly Free'; 2 = 'Free')
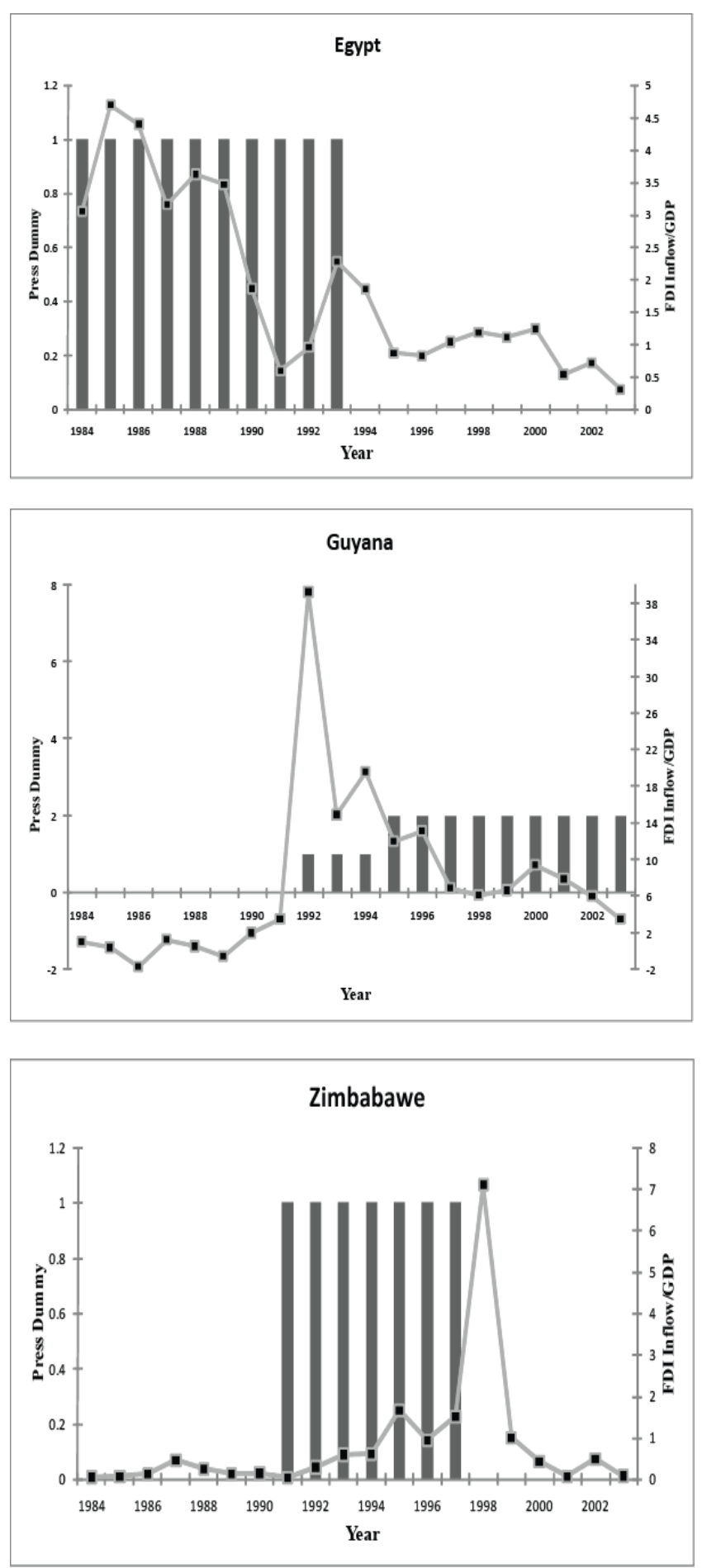
Figure 2.4: The Association between FDI and Press Freedom; Note: $0=$ 'Not Free'; 1 = 'Partly Free'; 2 = 'Free')
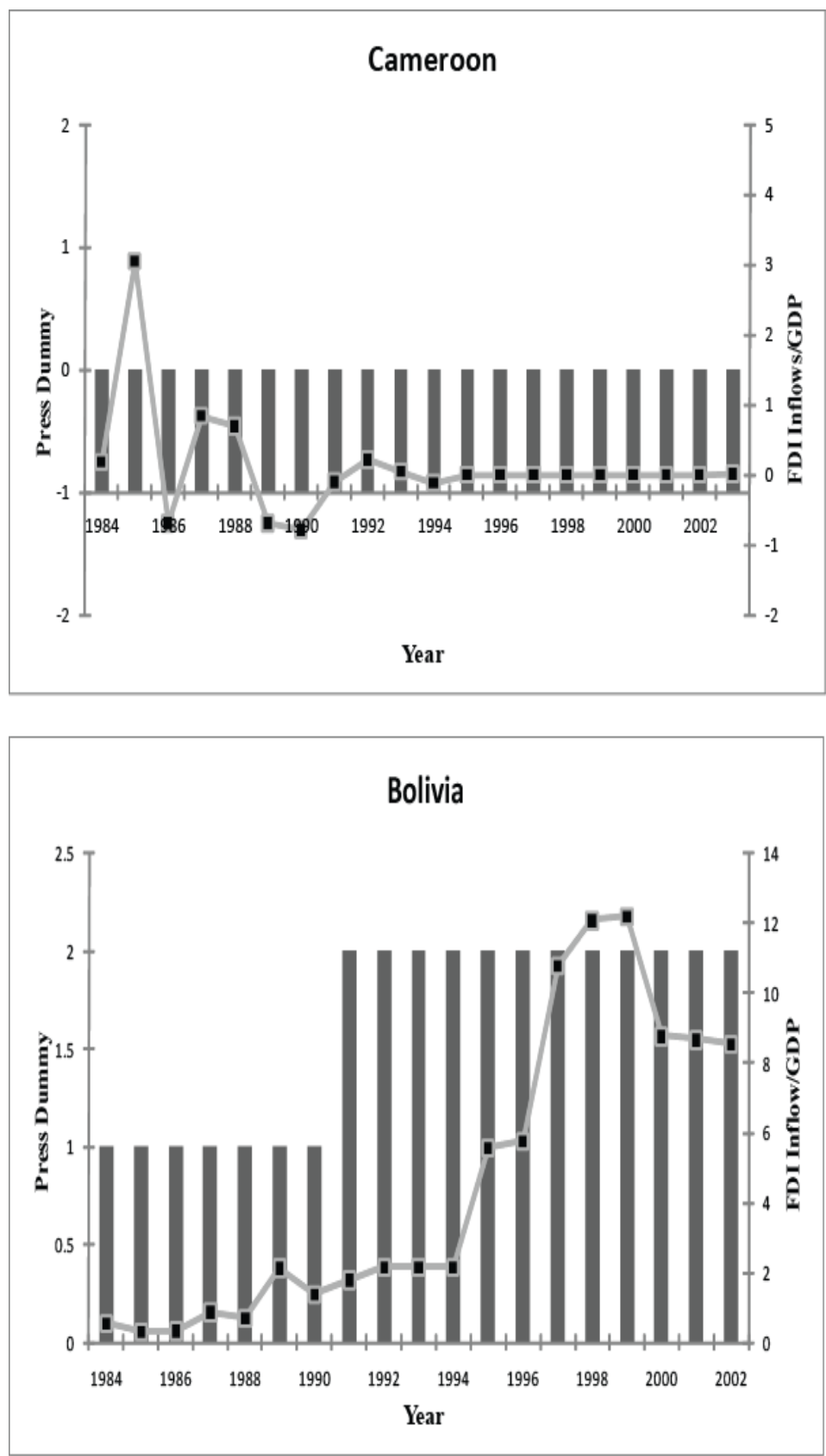
Table 2.1: OLS and Ordered Probit Showing Impact of FDI on Press Freedom

\begin{tabular}{lcc}
\hline VARIABLES & $(1)$ & $(2)$ \\
\hline FDI & $0.44^{* * *}$ & $0.03^{*}$ \\
Trade & $(0.12)$ & $(0.02)$ \\
& $0.04^{* * *}$ & $0.01^{* * *}$ \\
GDP per capita & $(0.02)$ & $(0.001)$ \\
& $0.001^{* * *}$ & $0.00003^{* * *}$ \\
Schooling & $(0.0001)$ & $(0.000001)$ \\
& $1.38^{* * *}$ & $-0.14^{* * *}$ \\
Democracy & $(0.42)$ & $(0.03)$ \\
& $4.03^{* * *}$ & $0.16^{* * *}$ \\
Resource Abundance & $(0.19)$ & $(0.01)$ \\
& -1.56 & $-2.04^{* * *}$ \\
Dummy for Sub Saharan Africa & $(2.75)$ & $(0.37)$ \\
Dummy for Latin America and the Caribbean & $6.32^{* * *}$ & $-0.28^{*}$ \\
& $(1.49)$ & $(0.15)$ \\
Dummy for Middle East and North Africa & -0.44 & $0.36^{* * *}$ \\
& $(1.39)$ & $(0.13)$ \\
Dummy for East Asia and Pacific & $-6.92^{* * *}$ & $-0.62^{* * *}$ \\
Dummy for South Asia & $(1.79)$ & $(0.16)$ \\
& $-7.85^{* * *}$ & $-0.40^{* * *}$ \\
Dummy for Europe and Central Asia & $(1.38)$ & $(0.14)$ \\
R-Squared & $-4.52^{* *}$ & 0.32 \\
Pseudo R-Squared & $(2.01)$ & $(0.20)$ \\
\hline & $-19.06^{* * *}$ & $-0.78^{* * *}$ \\
& $(2.66)$ & $(0.19)$ \\
& 0.81 & - \\
& - & 0.27 \\
& 764 & 1492 \\
\hline
\end{tabular}

Standard errors in parentheses, Year Dummies not reported $* * * \mathrm{p}<0.01,{ }^{* *} \mathrm{p}<0.05, * \mathrm{p}<0.1$

Column 1 represents OLS specification while Column 2 represents the Ordered Probit specification 
Table 2.2: 2SLS and Ordered-Probit with 2SLS Showing Impact of FDI on Press Freedom

\begin{tabular}{lcccc}
\hline VARIABLES & $(1)$ & $(2)$ & $(3)$ & $(4)$ \\
\hline & & & & \\
FDI & $1.71^{* *}$ & $1.76^{* *}$ & $0.50^{* * *}$ & $0.20^{* * *}$ \\
& $(0.87)$ & $(0.91)$ & $(0.16)$ & $(0.06)$ \\
GDP per capita & $0.0002^{* * *}$ & $0.0002^{* * *}$ & 0.0004 & -0.00001 \\
& $(0.0001)$ & $(0.0001)$ & $(0.0001)$ & $(0.00001)$ \\
Schooling & $1.26^{* * *}$ & 0.46 & $-0.14^{* * *}$ & $-0.28^{* * *}$ \\
& $(0.46)$ & $(0.62)$ & $(0.04)$ & $(0.04)$ \\
Democracy & $4.50^{* * *}$ & $5.56^{* * *}$ & $0.21^{* * *}$ & $0.51^{* * *}$ \\
& $(0.26)$ & $(0.69)$ & $(0.02)$ & $(0.06)$ \\
Resource Abundance & -1.49 & -0.35 & $-3.21^{* * *}$ & $-1.23^{* * *}$ \\
& $(6.22)$ & $(6.60)$ & $(0.76)$ & $(0.38)$ \\
Dummy for Sub Saharan Africa & $5.95^{* * *}$ & $8.99^{* * *}$ & 0.05 & $0.97^{* * *}$ \\
& $(1.95)$ & $(2.67)$ & $(0.22)$ & $(0.25)$ \\
Dummy for Latin America and the Caribbean & $-4.32^{* * *}$ & $-4.18^{* * *}$ & -0.06 & $0.25^{* *}$ \\
& $(1.56)$ & $(1.54)$ & $(0.12)$ & $(0.11)$ \\
Dummy for Middle East and North Africa & $-5.15^{*}$ & 0.61 & -0.01 & $1.50^{* * *}$ \\
& $(2.91)$ & $(4.27)$ & $(0.28)$ & $(0.38)$ \\
Dummy for East Asia and Pacific & $-9.78^{* * *}$ & $-7.34^{* * *}$ & $-1.02^{* * *}$ & 0.19 \\
& $(1.71)$ & $(2.52)$ & $(0.18)$ & $(0.22)$ \\
Dummy for South Asia & $-5.26^{* *}$ & $-4.55^{*}$ & $0.75^{* * *}$ & $0.91^{* * *}$ \\
& $(2.43)$ & $(2.73)$ & $(0.27)$ & $(0.22)$ \\
Dummy for Europe and Central Asia & $-21.57^{* * *}$ & $-22.001^{* * *}$ & $-1.30^{* * *}$ & $-0.74^{* * *}$ \\
& $(1.93)$ & $(2.003)$ & $(0.28)$ & $(0.26)$ \\
R-Squared & 0.77 & 0.76 & - & - \\
Pseudo R-Squared & - & - & 0.26 & 0.21 \\
Observations & 796 & 796 & 1701 & 1774 \\
\hline
\end{tabular}

Standard errors in parentheses, Year Dummies not reported

$$
\text { *** } \mathrm{p}<0.01, * * \mathrm{p}<0.05, * \mathrm{p}<0.1
$$

Column 1 and 2 represent 2SLS while Column 3 and 4 represent Ordered Probit with 2SLS

Column 1 and 3 represent the specifications with instrumented FDI

Column 2 and 4 represent the specifications with instrumented FDI and Democracy 
Table 2.3: OLS and Ordered Probit with Alternative Measure of FDI

\begin{tabular}{|c|c|c|}
\hline VARIABLES & (1) & $(2)$ \\
\hline FDI & $\begin{array}{l}0.16^{*} \\
(0.08)\end{array}$ & $\begin{array}{c}0.02 \\
(0.02)\end{array}$ \\
\hline Trade & $\begin{array}{c}0.05^{* * *} \\
(0.01)\end{array}$ & $\begin{array}{c}0.01 * * * \\
(0.001)\end{array}$ \\
\hline GDP per capita & $\begin{array}{c}0.001^{* * *} \\
(0.0001)\end{array}$ & $\begin{array}{c}0.00003^{* * *} \\
(0.000001)\end{array}$ \\
\hline Schooling & $\begin{array}{c}0.89^{* *} \\
(0.41)\end{array}$ & $\begin{array}{c}-0.10^{* * *} \\
(0.03)\end{array}$ \\
\hline Democracy & $\begin{array}{c}3.91^{* * *} \\
(0.19)\end{array}$ & $\begin{array}{c}0.16^{* * *} \\
(0.01)\end{array}$ \\
\hline Resource Abundance & $\begin{array}{c}5.27 \\
(4.41)\end{array}$ & $\begin{array}{c}-2.65^{* * *} \\
(0.33)\end{array}$ \\
\hline Dummy for Sub Saharan Africa & $\begin{array}{c}5.02^{* * *} \\
(1.55)\end{array}$ & $\begin{array}{c}-0.31^{*} \\
(0.15)\end{array}$ \\
\hline Dummy for Latin America and the Caribbean & $\begin{array}{l}1.49 \\
(1.37)\end{array}$ & $\begin{array}{c}0.31^{* * *} \\
(0.12)\end{array}$ \\
\hline Dummy for Middle East and North Africa & $\begin{array}{c}-5.49^{* * *} \\
(1.82)\end{array}$ & $\begin{array}{c}-0.73^{* * *} \\
(0.15)\end{array}$ \\
\hline Dummy for East Asia and Pacific & $\begin{array}{c}-5.75^{* * *} \\
(1.49)\end{array}$ & $\begin{array}{c}-0.50^{* * *} \\
(0.13)\end{array}$ \\
\hline Dummy for South Asia & $\begin{array}{c}-3.34^{*} \\
(1.98)\end{array}$ & $\begin{array}{c}0.38^{* *} \\
(0.20)\end{array}$ \\
\hline Dummy for Europe and Central Asia & $\begin{array}{c}-16.45^{* * *} \\
(2.86)\end{array}$ & $\begin{array}{c}-0.82^{* * *} \\
(0.18)\end{array}$ \\
\hline R-Squared & 0.79 & - \\
\hline Pseudo R-Squared & - & 0.27 \\
\hline Observations & 832 & 1630 \\
\hline
\end{tabular}

Standard errors in parentheses, Year Dummies not reported $* * * \mathrm{p}<0.01,{ }^{* *} \mathrm{p}<0.05,{ }^{*} \mathrm{p}<0.1$

Column 1 represents OLS specification while Column 2 represents the Ordered Probit specification 
Table 2.4: List of Countries

\begin{tabular}{|l|l|l|}
\hline Algeria & Ghana & Norway \\
\hline Argentina & Greece & Oman \\
\hline Australia & Guatemala & Pakistan \\
\hline Austria & Guinea-Bissau & Panama \\
\hline Bahrain & Guyana & Papua New Guinea \\
\hline Bangladesh & Haiti & Paraguay \\
\hline Barbados & Honduras & Peru \\
\hline Belgium & Hong Kong & Philippines \\
\hline Belize & Hungary & Portugal \\
\hline Benin & Iceland & Rwanda \\
\hline Bolivia & India & Saudi Arabia \\
\hline Botswana & Indonesia & Senegal \\
\hline Brazil & Iran & Sierra Leone \\
\hline Burkina Faso & Ireland & Singapore \\
\hline Burundi & Israel & Solomon Islands \\
\hline Cameroon & Italy & South Africa \\
\hline Canada & Jamaica & Spain \\
\hline Cape Verde & Japan & Sri Lanka \\
\hline Central African Republic & Jordan & St. Vincent and the Grenadines \\
\hline Chad & Kenya & Sudan \\
\hline Chile & Korea, Republic & Swaziland \\
\hline China & Kuwait & Sweden \\
\hline Colombia & Lesotho & Switzerland \\
\hline Congo, Dem. Rep. & Madagascar & Syria \\
\hline Congo, Rep. & Malawi & Thailand \\
\hline Costa Rica & Malaysia & Togo \\
\hline Cyprus & Mali & Trinidad and Tobago \\
\hline Denmark & Malta & Tunisia \\
\hline Dominica & Mauritania & Turkey \\
\hline Dominican Republic & Mauritius & Uganda \\
\hline Ecuador & Mexico & United Arab Emirates \\
\hline Egypt & Morocco & United Kingdom \\
\hline El Salvador & Mozambique & United States \\
\hline Fiji & Nepal & Uruguay \\
\hline Finland & Netherlands & Venezuela \\
\hline France & New Zealand & Zambia \\
\hline Gabon & Nicaragua & Zimbabwe \\
\hline Gambia & Niger & \\
\hline Germany & Nigeria & \\
\hline & & \\
\hline
\end{tabular}


Table 2.5: Data Sources

\begin{tabular}{|l|l|}
\hline Variable & Source \\
\hline FDI/GDP & $\begin{array}{l}\text { United Nations Conference in } \\
\text { Trade and Development (UNCTAD) }\end{array}$ \\
\hline Press Freedom Index & Freedom House Organization \\
\hline Trade/GDP & WDI (2005) \\
\hline Population & WDI $(2005)$ \\
\hline GDP per capita & WDI (2005) \\
\hline Exchange Rate & Penn World Tables \\
\hline Schooling & Barro and Lee Dataset \\
\hline Resource Abundance & Sachs and Warner Dataset(1995b) \\
\hline Democracy & Polity IV Dataset \\
\hline Corruption & ICRG Dataset \\
\hline Telephones (per 1000 people) & WDI (2005) \\
\hline Internet Penetration & WDI (2005) \\
\hline Financial Development & Beck, Demirguc-Kunt and Levine (2000) Dataset \\
\hline Growth & WDI (2005) \\
\hline
\end{tabular}




\section{Chapter 3}

\section{Countering Terror: The Importance of a Free Press}

\section{INTRODUCTION}

In the modern world, one of the most hard-pressed threat and challenge faced by all across the globe is transnational terrorism. This phenomenon, though gained paced recently, it not however a recent invention. As Keefer and Loayza (2008) points out, terrorism is in fact as old as war. However, as opposed to the motives of war, the motives of terror attacks are primarily two-fold. Firstly it tries to spread a political or social message by intimidating an audience beyond that of the immediate victims and secondly, it has the purpose of demonstrating its violent capability often with the goal to pressurize governments of countries. As pointed out of Enders and Sandler (2006), they tend to broaden their audience and induce a severe sense of anxiety in the society by making their actions appear as random. In recent years, terrorist incidents have taken up new patterns and have shifted their targets from the military to civilians. Alongside, the methods and planning that go behind such terror strikes have become increasingly planned, intelligent and sophisticated. Accordingly, countering such terror threats also require a country to be equipped with sound political and economic 
institutions as mechanisms to not only combat, but also prevent the occurrence of such incidents.

The importance of sound institutions for growth and development of countries has been well established in the economic literature. Studies have shown how lack of well established economic and political institutions lead to failure of policy initiatives. In this established list of institutions, a very addition is the consideration of media as an institution. This strand of literature looks at the media sector as an essential anchor that, if made unbiased and effective, can help an economy progress in its path of economic development by generating a pool of informed and aware populace and by acting as a "handcuff" for a "leviathan government".

While many researchers have looked at how terrorist incidents negatively affect a country's economic progress in a multitude of ways and have independently established various forms of well-developed institutions as imperative for economic growth and development, the interaction between the two has been sparsely looked at. This paper attempts to bridge the gap in this respect and tries to investigate how a free unbiased media impacts terrorist incidents in a country.

Section 2 provides a brief review of the literature. Section 3 elaborates on the motivation and hypothesis. Section 4 and 5 explains the data and methodology used for the empirical validation of the hypothesis while Section 6 elaborates the empirical results. Section 7 enlists the robustness checks and Section 8 concludes.

\section{LITERATURE REVIEW}

Media, the broad reference encompassing print, internet, television and advertisements plays an indispensable role in informing and shaping the mindset of an economy, be it at the local or the national level. It is not merely a representation of the culture of a country but is an "institution" that has the largest reach and the most immediate effect on the population at 
large. The indispensability of media is largely owing to its capacity to reach people at every nook of the society. It bears the brunt of channelizing information, biased or otherwise to the masses. It has the sole potential to make government and businesses accountable and enable the populace to make more informed decisions.

A competitive, free media, both print and electronic, will be more transparent in its activities and will posses enriched economic and functional environment. In the presence of abundant private capital, the media outlets need not depend on funds from the government for their functioning. This enables them not to become a spokesperson for the government and frees them from the burden of circulating biased and manipulated information. Mehfuz (2002) mention that with the advent of privatization of electronic media in Bangladesh, the media houses have ceased to be mere extensions of the 'government's propaganda mechanism' and are thinking freely. Coyne and Leeson (2008) gives extensive examples from Romania and Vietnam where various privately owned media-outlets were dependent on the state for infrastructure and distribution network and hence generated biased opinions. Kassem (2002) points out that the Egyptian press is a prominent stronghold of the government and is prime target for corruption. 'Since the region is ruled either by monarchies or military dictatorships that have huge budgets they can use to embellish their image in the media.' A significantly high (to the proportion of 90\%) of the previously "independent" press was backed by one or more of the above-mentioned regimes. This led to replacement of sales and marketing managers to be replaced by 'pushy publishers' trying to impress the regimes' embassies. Furthermore, the distribution figures of these publications were also never audited and this destroyed competition.

As regards the relation between quality of institutions in a country and incidents of terrorism in the same, researchers have mostly looked at the relation between terrorism and democracy and two contradicting perspectives exist in that regard. One perspective argue that terrorism is supported by the higher amounts of civil liberties enjoyed in a democracy as against autocracies. As democratic governments on average respect the privacy of its 
citizens more, counterterrorism is more difficult and more restrained. Based on findings that democracies are more likely victims of terrorism, Eubank and Weinberg (2001) claim that a stable democracy and terrorism go hand in hand. Blomberg et al. (2004) find that high-income democratic nations are more prone to be international terrorist targets. The finding is supported by Blomberg and Hess (2005). Studies by Li (2005), Burgoon (2006) and Krueger and Laitin (2007) show that controlling for the effect of democracy, political changes towards more democratic forms of government is associated with an increase in terrorist activities.

The other perspective argues that democratic regimes have a terrorism reducing effect. Eyerman (1998) indicate that stable democracies are less prone to be victims of transnational terrorism. Kurrild-Klitgaard et al. (2006) also find that democracy has a terrorism dampening effect. However, countries undergoing democratic change are more prone to terrorism because of the accompanied instability during the change. Li (2005) suggests that democracy is negatively related to international terrorism and that the trade-off between civil liberties and security needs under such regimes need to be gauges carefully so as to completely understand the impact of open societies on terrorism. Drakos and Gofas (2006a) however find the democracy-terrorism linkage to be truly insignificant.

\section{MOTIVATION and HYPOTHESIS}

While terror struck the financial capital of India on November 26, 2008, the media of the country gave a round-the-clock coverage of the mayhem. People, not only in the country, but across the globe got to see the first hand evidence of atrocity which unfortunately lasted for sixty hours. During the coverage, the media apart from giving a live update of the incident also interacted profusely with the common man to hear out their reactions, anxiety and grievances. The coverage was widely applauded by many but also called amateurish and dramatic by others. It was alleged that the coverage gave terrorists an undue footage and 
also made it easier for them to use the visuals to their advantage. It was claimed that many hostages could have been saved had the media not reported where people were hiding or crying out for help inside the plush hotels. The involvement of the common man in voicing their angst over the matter was also said to evoke communal repercussion. In a country like India, where diversity is the rule, that could be dangerous. Such scathing criticisms of media coverage prompted the News Broadcasters Association to unveil self regulatory guidelines for telecast of sensitive events.

However, it cannot be denied that despite some of its negative effects, such coverage brought into focus the loopholes and laxity in the country's counter-terrorism and threatmitigation structure. Had it not been because of the initiative of the media, the common man would not have truly known the intensity of the threat faced at home and the strong voices of the people would have never ruffled the political feathers. Such was the impact that the central government sanctioned the proposal to form the National Intelligence Agency (NIA) in the lines of the Federal Bureau of Investigation within a day in the parliament. Further important decisions like provision of National Security Guard nodes in all important cities were also discussed. The home ministry was also overhauled. The incident has further led to the promise of a new anti-terror law to be put in place. A privatized and free media along with its role of being an unbiased informer is also understood to be driven by profit motives. It highlights information which would have maximum appeal to the masses. In the process the extent of broadcast does sometimes go overboard but never fails to draw the attention of the people who have complete right to information and the freedom thereof to judge the same. As in the case of the above-mentioned incident, despite the alleged drawbacks, the media did play a role in being a voice for and of the people. In a free society, it did emerge as a watchdog of the government, questioned its accountability and brought about important policy and strategic changes thus upholding the promises of a democracy.

The above incident is a real example as to how a free media that is deemed important for general economic development can be doubted as regards its role in combating terror 
incidents. This is what this paper tries to investigate empirically. The analysis is two pronged. Firstly the paper attempts to see the influence of having a free press on future rate of terrorism. Secondly, it addresses how the same works in conjunction with a democratic institutional set-up. So, the paper hypothesizes that a free press will have a terror dampening effect. A free press, by disseminating information, directly raises general awareness amongst the populace. It not only showcases the impact of such incidents but also brings forth the

root causes of the same. People become aware of the national and international conditions associated with such fatal incidents of terrorism. The free flow of information enables them to contextualize such incidents and make informed decisions and form opinions on that basis. With a free press in action the authorities also have less scope of fabricating or hiding information and this raises their accountability. This creates a healthy environment of checks and balances. With more awareness and pressure of accountability, the liability of the authorities to take attentive measures also rises, all of which contribute towards combating future incidences of terrorism to a great extent. Apart from this, a free press indirectly helps combat terrorism by empowering and enabling a democracy.

\section{DATA}

This paper uses a cross-country framework to look at the impact of a free press on terrorism. The proxy for terrorism has been taken from the Global Terrorism Database published by the U.S Department of Justice. The Global Terrorism Database (GTD) is composed of terrorist events recorded for the entire world from 1970 to 2004. The database employs a broad definition of terrorism namely "the threatened or actual use of illegal force and violence to attain a political, economic, religious, or social goal through fear, coercion, or intimidation". The database is designed to document every known terrorist activity across countries and over time. This database only reports international terrorist incidents. The proxy of terrorism used in the paper is the total number or international terrorism incidents 
in a country in a given year. The database is comparable to the other widely data source used for empirical research in terrorism, namely, the (International Terrorism: Attribute of Terrorist Events) ITERATE dataset (Mickolous et al. (2003); Enders and Sandler (2004)). ITERATE dataset too enlists the number of international terrorist incidents faced by a country. The other database used in this regard is the Global Terrorism Index of World Market Research Center (Abadie (2006); Abadie and Gardeazabal (2008)). This however is an index of overall threat perception for 2003-04 and not the actual number of terrorist attacks. The benefit of using the GTD database is that it provides actual number of terrorist incidents which is more appropriate for risk assessment purposes rather than any index of the same.

The primary explanatory variable for the analysis is the level of media or press freedom. The degree of press freedom of a country is captured as an index compiled by Freedom House. The index captures three aspects: legal (laws and regulations pertaining to the media sector), political (political pressure, control and violence on the contents of the media) and economic (economic pressure and control on the sector). The aspects are covered by twenty-three methodology questions. The Press Freedom Index as compiled by Freedom House originally runs from 0 to 100 with higher scores indicating less freedom of the press. For the purpose of analysis, the scores have been rescaled whereby higher scores now mean more free a press.

To account for the indirect impact of a free press on terrorism in the form of empowering good institutions, the main proxies considered thereof are those of democracy. Firstly an index of democracy is used for the purpose. Then the functionality of a democracy is captured by the extent of civil and political rights offered by a nation. The paper examines the effect of a free press in conjunction with the level of democracy (captured in either way) in impacting occurrences of terrorist incidents. For democracy the paper has used the Vanhanen's democratization index (VDI henceforth). The VDI is based on two dimensions, public contestation and the right to participate, which are named as competition and participation, respectively. Competition is based on the electoral success of the smaller parties and 
calculated by subtracting the percentage of the votes won by the largest party from $100 \%$. For participation, the percentage of the population that actually voted in these elections is used as a measure. For democracy, the author constructed an equally weighted index of democratization (henceforth democracy) by multiplying competition and participation and dividing the outcome by 100 which the author considers as the principal indicator of democracy (Vanhanen (1992); pp. 22-23).

For political and civil rights the paper uses indices of political rights and civil liberty published by Freedom House. Political rights refer to the freedom of people to participate in the political process by exercising rights to vote, organize political parties to compete for public office, and form an effective opposition to elect representatives who devise public policies and are accountable for their actions. Civil liberties entail freedom of expression and religious belief, the prevalence of the rule of law, right to form unions, freedom to marry, and freedom to travel. It also signifies the autonomy of people without interference from the state. These two indicators provided on an annual basis are derived from cross-country surveys. Each of these indices is measured on a scale of 1 (best) to 7 (worst) points. Following Trumbull and Wall (1994) and Younas (2008), a combined freedom index has also been used by adding indices of political rights and civil liberties. The combined index thus ranges from 2 to 14 with lower scores being better. While considering the econometric analysis of the hypothesis, the analysis controls for other country-specific factors that are believed to have a bearing on terrorism. The controls include per capita income of a country that captures the general economic standard of a nation, literacy proxied by years of primary schooling, infrastructure proxied by telephone mainlines per 1000 people, total population that captures the size of the country and an index of Ethnolinguistic fractionalization capturing possibilities of internal tension in a country. Apart from that the analysis considers an extensive set of regional dummies Eastern Europe, Latin America and the Caribbean, Middle East and North Africa, Central Asia, South Asia, East Asia and the Pacific and Sub-Saharan Africa based on standard World Bank classification. Dummies have also been included to capture whether 
a country is landlocked or an island to capture if geography has a role to play and also considering whether a country belongs to OPEC. The study also controls for legal origin of a country since it is established to be a determinant of the legal environment of a country (Porta et al. (1998)). Finally share of the population belonging to religious affiliations namely Catholics, Protestants and Islam ${ }^{1}$ has been considered.

The data for the control variables have been primarily taken from the World Development Indicators (2007) database published by the World Bank. The dummies for landlocked/island and the proportions of religious affiliations have been taken from Andrew Ros $\mathrm{Q}^{2}$ while the legal origin dummies are based on classification by Porta et al. (1998). The data for ethnolinguistic fractionalization has been taken from Roeder (2001).

\section{METHODOLOGY}

Considering that the dependent variable in this analysis is a count variable, ordinary least square (OLS) will be inappropriate for deriving estimation results. The terrorism data shows significant evidence of overdispersion 3 , whereby a Poisson count model, which assumes that the conditional mean and standard deviation and roughly equal, is also not feasible. A negative binomial model is thus the most appropriate for the purpose. A few considerations suggest that the negative binomial regression works better than the alternative specification of running a zero-inflated negative binomial model. First, the dataset inherently does not include those years in which there was no international terror incident in a country. Also, several important papers in this literature have relied on the negative binomial model (for example, see Krueger and Maleckova (2003); Burgoon (2006); Krueger and Laitin (2007)).

The econometric model is specified for a sample of 121 developed and developing countries

\footnotetext{
${ }^{1}$ The value of the proportions of population belonging to religious affiliation is fixed at its 1980 values. This is following standard (Rose (2006); Younas (2008)).

${ }^{2}$ Dr. Rose has graciously provided the datasets in his website http://haas.berkeley.edu/ arose.

${ }^{3}$ This is adjudged by the Likelihood Ratio (LR) test. The significance level of the test is adjusted to account for the truncated sampling distribution of alpha hat. Here the results are significant and the likelihood ratio test for overdispersion rejects the null hypothesis of alpha $=0$. The statistically significant evidence of overdispersion indicates that Negative Binomial model is preferred to Poisson Regression Model.
} 
spanning over a period 1995-2004. The choice of sample period is based on the availability of quantitative data for the primary independent variable of interest - press freedom. The qualitative data on the freedom of the press as published by Freedom House starts from 1994 onwards, before that the data is in qualitative form. The econometric model followed for the analysis also takes into account any possibility of simultaneous causation between terrorism and the independent variables of interest. Wooldridge (2003) states that if we assume that the error term $\mu_{i t}$ is uncorrelated (a standard assumption) with all past endogenous and exogenous variables, then lagged endogenous variables in simultaneous models are treated as predetermined variables and they are uncorrelated with $\mu_{i t}$. Following this technique, one-year-lagged values for all independent variables have been used.

Intuitively, this makes sense since economic, social, and political conditions may take some time to influence a country's vulnerability to future attacks of terrorism. Moreover, this technique also overcomes any likely problem of contemporaneous correlation. Consequently, in the cross-section specification data on incidents of terrorism are averaged over the period 1995 to 2004, while the data for all independent variables are averaged from 1994 to 2003.

As explained in the hypothesis, the econometric analysis addresses both the direct and indirect impact of a free press on terrorism incidents. Accordingly, the following equations outline the benchmark regression specification for each respectively.

$$
\begin{gathered}
\text { TerroristAttacks }_{i t}=\alpha_{0}+\beta_{1} P F_{i t}+\beta_{2} X_{i t}+\varepsilon_{i t} \\
\text { TerroristAttacks }_{i t}=\alpha_{0}+\beta_{1} P F_{i t}+\beta_{2} \text { Institutions }_{i t}+\beta_{3} X_{i t}+\varepsilon_{i t} \\
\text { TerroristAttacks }_{i t}=\alpha_{0}+\beta_{1} P F_{i t}+\beta_{2} \text { Institutions }_{i t}+\beta_{3}\left(\text { Institutions }_{*} \text { PF }\right)_{i t}+\beta_{4} X_{i t}+\varepsilon_{i t}
\end{gathered}
$$

Where equation (3.1) captures the direct impact of a free press on incidences of international terrorism, equation (3.2) elucidates how prominent the impact is, given levels of complementary good institutions. Equation (3.3) captures the impact a free press can 
indirectly have via good institutions, namely democracy. The specifications have been designed following Bandyopadhyay and Younas (2009) who focus on determinants of domestic terrorism and Chowdhury (2004) who elucidate how democracy and a free press together help reduce corruption. In the equations, $P F_{i t}$ is Press Freedom in country "i" at time "t" and $X_{i t}$ is the matrix of other control variables of country "i" at time " $\mathrm{i}$ ". Institutions $s_{i t}$ is the quality of institutions (namely democracy and its various components)in country "i" at time "t" and (Institutions $*$ PF $)_{i t}$ captures the interplay between good institutions and the nature of media in country "i" at time "t" 4

\section{RESULTS}

As mentioned above, the paper analyzes both the direct and indirect impact of a free press on international terrorism faced by a country. The benchmark specification followed for the analysis is a panel analysis.

The panel analysis has been reported in tables (3.1), (3.2) and (3.3) with each table corresponding to equations (3.1) through (3.2). Column (1) of Table (3.1) only captures the relation between the extent of press freedom and terrorism without controlling for any other economic or demographic attribute of a country. Column (2) and (3) includes the variable and fixed controls accounting for other country specific characteristics and column (4) includes ethnolinguistic fractionalization along with all the control variables. Through all the specifications, the coefficient of press freedom is found to be negative as expected and statistically significant as well. For interpretation of the results, marginal effects are calculated which shows that for example, in column (4), for the press freedom index ranging from 0 to 100 , a 10 unit increase in the index would lead to a decrease in the predicted number of terrorist events by 22.7 percent at the average.

\footnotetext{
${ }^{4}$ To ensure there is no problem of multicollinearity in the specification, the Variance Inflation Factor (VIF)is tested for. It measures the inflation in the variances in each parameter estimate due to collinearities among regressors. A VIF > 10 implies significant collinearity problem. In this case, the VIF estimates reveal that none of the VIF estimates are more than 10 implying that there is no problem of multicollinearity.
} 
Table (3.2) follows equation (3.2). The econometric analysis pertaining to this specification captures how press freedom performs in influencing terrorism when controlled for the quality of institution, namely democracy. In doing so, the analysis first controls for the aggregate index of democracy (in columns 1 and 2) and then separately for its two components: competition and participation (in column 3, 4 and 5, 6 respectively). The results show that controlling for the aggregate condition of democracy, or controlling for the condition of each of its aspects, the level of press freedom still has a negative coefficient statistically significant across all specifications. As reiterated by the marginal effects, a 10 unit increase press freedom decreases the predicted number of terrorist activities by 20 to 30 percent at the average across specifications. Interestingly enough, the coefficients of the aggregate measure of democracy as also its individual components are seen to be positive and statistically significant across specifications, as alleged in other literature.

Table (3.3) repeats the specification followed in Table (3.2) but substituting the extent of political rights and civil liberties as proxies of institutional quality in a nation. Column 1 and 2 controls for the combined proxy of political rights and civil liberties, column 3 and 4 controls for civil liberties and column 5 and 6 controls for political rights. Here too, across specifications, press freedom has a negative coefficient and has statistical significance when controlled for the combined proxy and for political rights separately. Also, considering that for the proxies of political right and civil liberty lower scores imply better condition, the results show that by themselves, the combined condition of civil liberty and political right and higher political right itself makes a country more prone to terrorist attacks. However, the results also show that having greater civil liberties reduce terrorism (depicted by the positive and statistically significant coefficient).

This, as also the positive coefficient in Table 3.2 for democracy and its components finds support in the extensive literature which claim that democracy and its many aspects (like higher political rights and civil liberty, greater participation and higher competition among political groups) has a tendency to make a country a lucrative target for terrorists, owing 
to its flexible and tolerant environment. The diversity in opinion and action harbored by a successful democracy makes it easier for terrorist to identify multitude of excuses to express their displeasure. This can also be explained well in terms of India, the world largest and one of the most successful democracies. It houses a multiparty democracy with varying degree of political opinion and allegiance and has an extremely diverse population with varied religious affiliations. The country also allows a free environment with tolerance towards all actions and opinions. This very environment, while upholds the true essence of a democracy, also more often than not, leads to various repercussions at home and outside. Many a times, these have been the prime reasons for terrorist attacks faced by the country.

Table 3.4 captures the indirect impact of a free press on terrorism, via the channel of a sound democracy. As specified in equation (3.3), here an interaction term is introduced $(\text { Institutions } * P F)_{i t}$. It is the coefficient of the interaction term that is the focus of attention here. When the composite index of democracy as well as its components (competition and participation) is considered, the interaction term has a negative and statistically significant coefficient across specifications. This is in-keeping with the fact that the democracy score as also for its components, higher scores are better. Table 5 does the same exercise but considers political rights and civil liberties are proxies of a sound democracy. In this case, considering that for the scores of political rights and civil liberties, the higher scores imply worse condition, the coefficient of the interaction term is rightfully positive and statistically significant.

To gain a better insight into the statistical interpretation of the specification, the partial derivative of the dependent variable with respect to press freedom is considered:

$$
\frac{\delta \text { TerroristAtacks }_{i t}}{\delta P F_{i t}}=\beta_{1}+\beta_{2} \text { Institutions }_{i t}
$$

Considering the median value of the sample for the composite index of democracy and solving for column 2 of table 3.4 reiterates that when brought together, a free press and a 
democracy together reduces terrorism. Now, the composite democracy measure runs from 0 to 24 implying that for higher values of the same (meaning a better functioning democracy), implying that a free press will have a bigger impact in dampening terrorism as the quality of democracy improves. The results are similar when the components of democracy (competition and participation) are considered likewise. Doing the same for column 2 of table 3.5, it is found that considering the median value of the combined civil liberty-political right index, the overall impact is seen to be terrorism mitigating. The above findings are encouraging because on one hand they show that a free press has a strong indirect effect in dampening future occurrences of terrorism, via a strong democracy. The results, on the other hand, also depict that a free press while is effective in combating terrorism almost in all conditions, it performs its role better, the stronger the foundation of the democratic institution. It also shows that while left to itself a democracy can be vulnerable to terrorist attacks, a free press can empower it further and effectively ensure a counter. The implication of the results is clearly depicted in Figure 3.1. The figure is a graphical representation of column (2) of Table 3.4. The figure plots how increase in the index of press freedom is related to number of terrorist incidents in the future. For a given level of democracy, the figure clearly shows that higher press freedom is terror dampening. The figure further reveals that as the quality of democracy itself strengthens, the impact of a free press is strengthened as well. As shown in the diagram, each of the three lines corresponds to three levels of democracies. As the score for democracy increases (implying a stronger democratic institution), the slope of the line becomes steeper meaning a greater impact of a free press.

\section{ROBUSTNESS}

To test the robustness of the analysis, the analysis undertakes a cross-sectional analysis. Like the panel analysis, the crosssectional analysis also tests for the direct and indirect impact of a free press on future occurrences of terrorism. While the panel analysis seeks to capture 
short run effects, the cross-section tends to capture the effect in the long run. Further, the cross-section also eradicates the possibility of any "noise" that the panel data might be capturing, since the terrorism data is random and erratic. In constructing the cross section dataset, the dependent variable is the number of terrorist incident in the final year while the control variables are the average of the previous years, thus maintaining the essence of the lagged analysis and avoiding endogeneity issues. Reported in Tables 6 though 8, the cross section results capture the direct and indirect impact of a free press. The results confirm the previous findings, thus strengthening the claim.

An alternative index of democracy as propounded by the Polity IV Project database has been used. The coefficients and signs of the variables of interest remain intact across specifications for the use of this alternative proxy of democracy. Thirdly, as seen in Bandyopadhyay and Younas (2009), in place of the composite index of ethnolinguistic fractionalization, three alternate indices of ethnic, language and religious fractionalization are introduced. These indices range from 0 to 1 with higher values implying a higher probability that two people selected from the same country have a higher probability of belonging to two different groups. The data for this has been taken from Alesina et al. (2003). Both the panel and cross-section analysis retain their sign and statistical significant with this alternative specification. In another specification the level of economic freedom of a country is controlled for and the results remain robust. Further, a subsample is considered for only developing countries and the results still hold robust across specifications.$^{5}$

\section{CONCLUSION}

This paper is an attempt to reestablish the importance of a free press in the context of combating the most dreadful threat faced by countries in current times - terrorism. Considering the case of transnational terrorism, the robust analysis presented above establishes

\footnotetext{
${ }^{5}$ To test possible non-linearity in the relation, square of the independent variables of interest were added. However, those coefficients were statistically and economically insignificant across specifications.
} 
that a free press does have a mitigating impact on terrorism. The importance of the paper extends further to substantiate that, though a democracy has often been criticized to be terror-inviting, when empowered by a free press, the two together have a strong terror dampening effect.

In isolation, a democracy seems to have a positive impact on terrorism while a free press always has a negative impact on the same. However, when brought together, the two has a definite negative impact on terrorism. The analysis is robust not only to alternate specification and both panel and cross sectional analysis, but also to the use of alternative control variables. The strength of the analysis also lies in the fact that not only is it tested for widely used composite proxies of democracy, but is also been tested on proxies capturing various other aspects of democracy and the claim remains robust throughout.

The analysis is not only important as it upholds the importance of having a free press and a sound democracy, but also establishes how important it is to empower a democracy with a free press and this definitely has sound policy implications. This is especially for countries weaker on either front as also for all countries plagued by threats or actual incidents of terrorism. It also refutes the doubt that lurked about the role of a free press in dealing with the 26/11 terror incident in India. Considering the detailed analysis, it can be safely claimed that the free press led to a positive impact at the end of it, if anything. 


\section{Table 3.1: The Impact of a Free Press on Future Incidents of Terrorism}

\begin{tabular}{|c|c|c|c|c|}
\hline VARIABLES & $(1)$ & $(2)$ & $(3)$ & $(4)$ \\
\hline Press Freedom & $\begin{array}{c}-0.0100^{* * *} \\
(0.0032)\end{array}$ & $\begin{array}{c}-0.0164^{* * *} \\
(0.0047)\end{array}$ & $\begin{array}{c}-0.0209^{* * *} \\
(0.0042)\end{array}$ & $\begin{array}{c}-0.0227^{* * *} \\
(0.0047)\end{array}$ \\
\hline $\begin{array}{l}\text { GDP per cap (const } 2000 \\
\text { USD) }\end{array}$ & & $0.0446^{*}$ & -0.0054 & 0.0049 \\
\hline Total Population & & $\begin{array}{c}(0.0247) \\
0.000002^{* * *} \\
(0.0000004)\end{array}$ & $\begin{array}{c}(0.0286) \\
0.000001^{* * *} \\
(0.0000003)\end{array}$ & $\begin{array}{c}(0.0296) \\
0.000001^{* * *} \\
(0.0000003)\end{array}$ \\
\hline $\begin{array}{l}\text { Infrastructure } \quad \text { (per1000 } \\
\text { people) }\end{array}$ & & $\begin{array}{c}-0.0204^{*} \\
(0.0105)\end{array}$ & $(0.0138)$ & $(0.00137)$ \\
\hline $\begin{array}{l}\text { Share of Gross Primary } \\
\text { Edu }\end{array}$ & & $\begin{array}{c}0.0226^{* * *} \\
(0.0044)\end{array}$ & $\begin{array}{c}0.0109^{* * *} \\
(0.0042)\end{array}$ & $\begin{array}{l}0.0066 \\
(0.0045)\end{array}$ \\
\hline Regional Dummies & & & YES & YES \\
\hline Legal Origin Dummies & & & YES & YES \\
\hline Landlocked Dummy & & & YES & YES \\
\hline Island Dummy & & & YES & YES \\
\hline Religion & & & YES & YES \\
\hline OPEC Dummy & & & YES & YES \\
\hline ELF & & & & $\begin{array}{c}0.532 \\
(0.383)\end{array}$ \\
\hline Constant & $\begin{array}{c}3.403^{* * *} \\
(0.197)\end{array}$ & $\begin{array}{c}1.206^{* * *} \\
(0.384)\end{array}$ & $\begin{array}{l}1.044^{*} \\
(0.584)\end{array}$ & $\begin{array}{l}1.031^{*} \\
(0.570)\end{array}$ \\
\hline Log Pseudolikelihood & -2702.42 & -2065.81 & -1946.94 & -1907.64 \\
\hline Sample Size & 714 & 714 & 714 & 714 \\
\hline
\end{tabular}




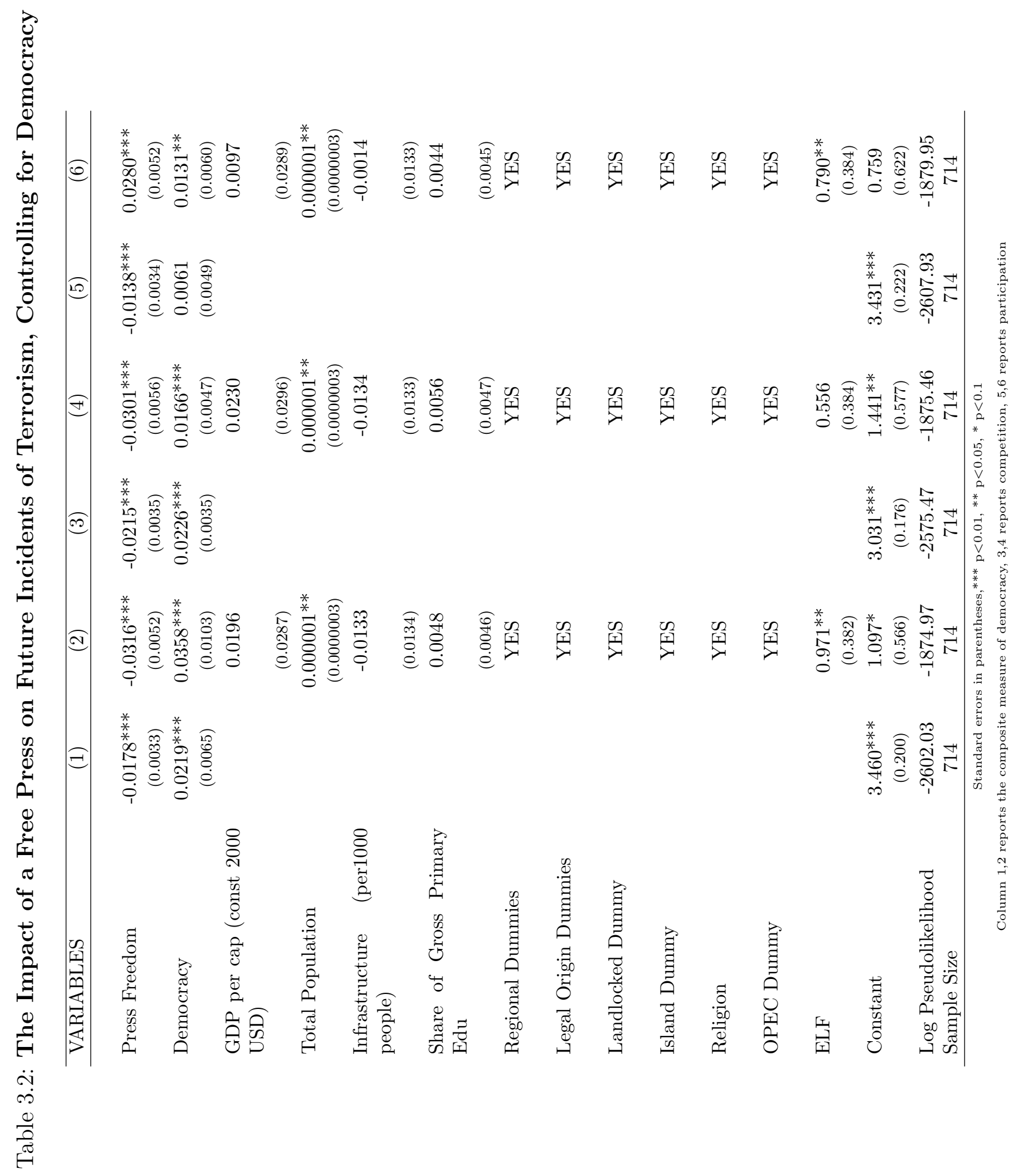




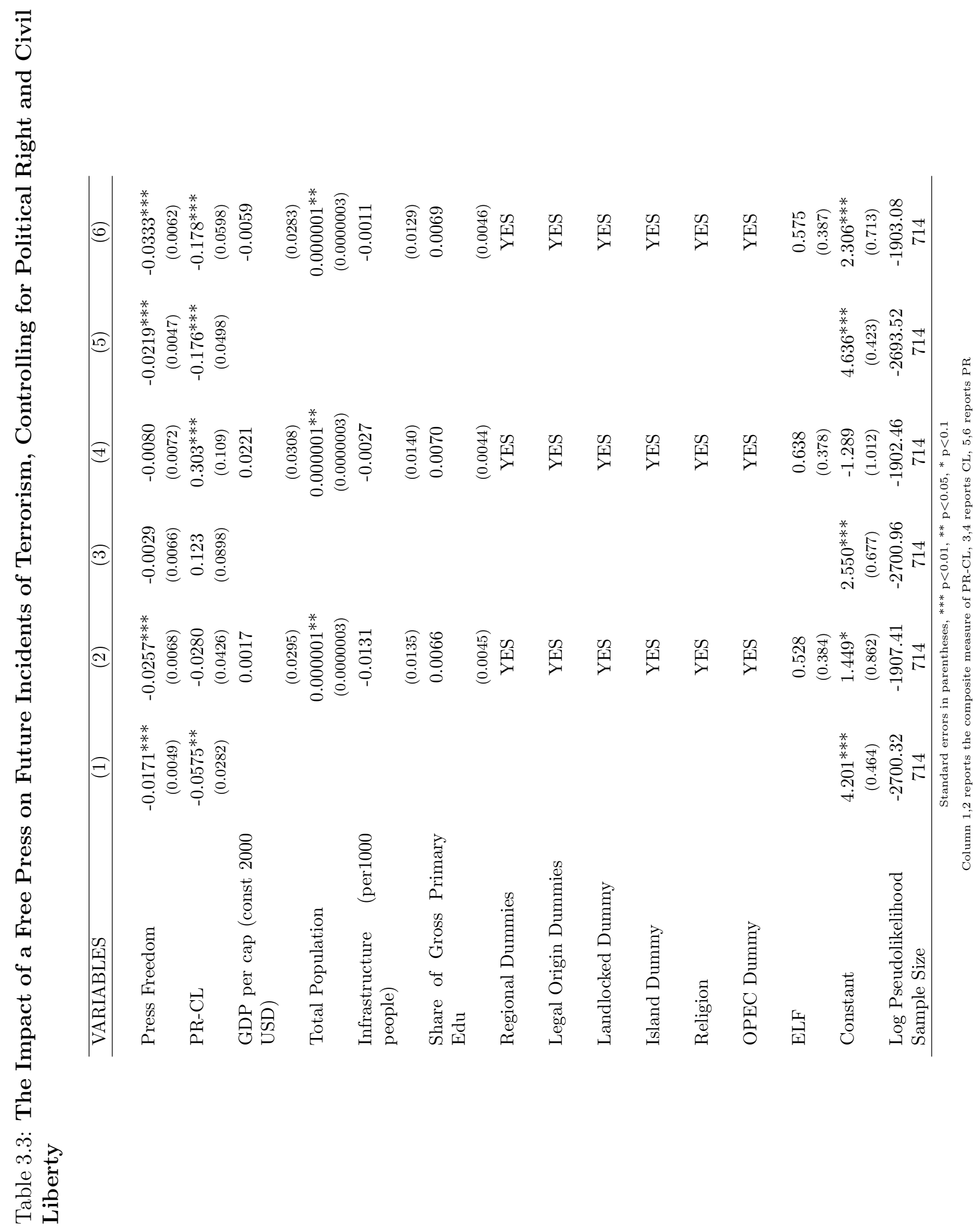




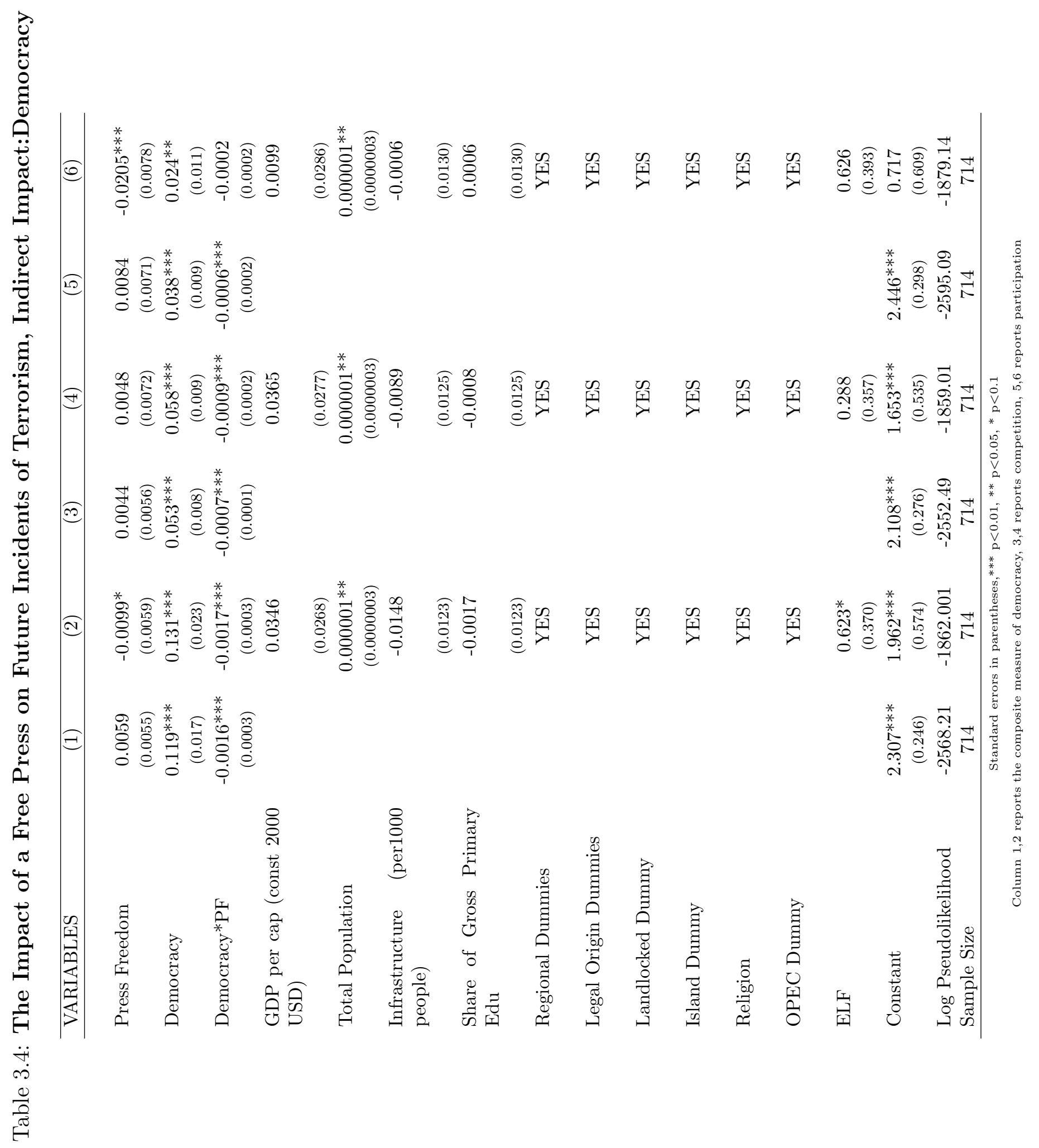




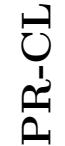

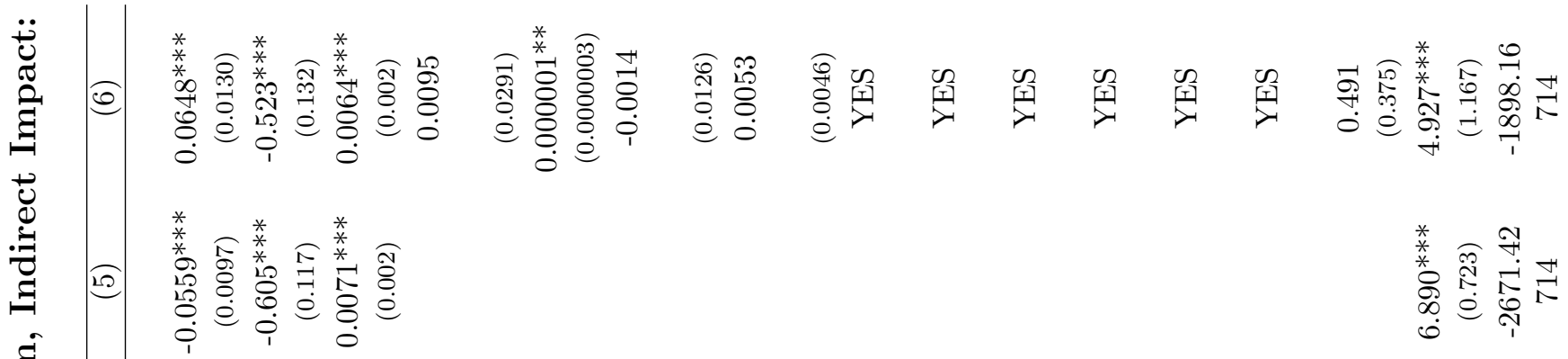

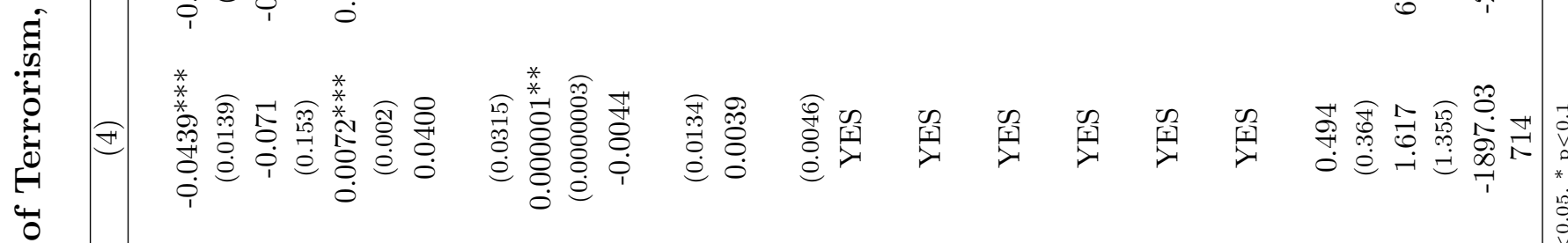

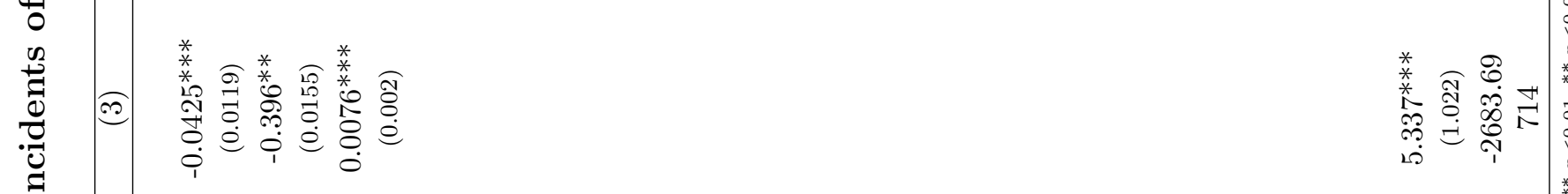

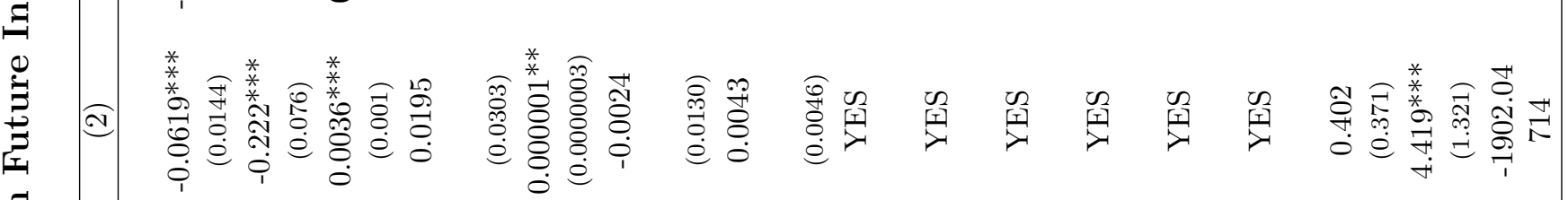

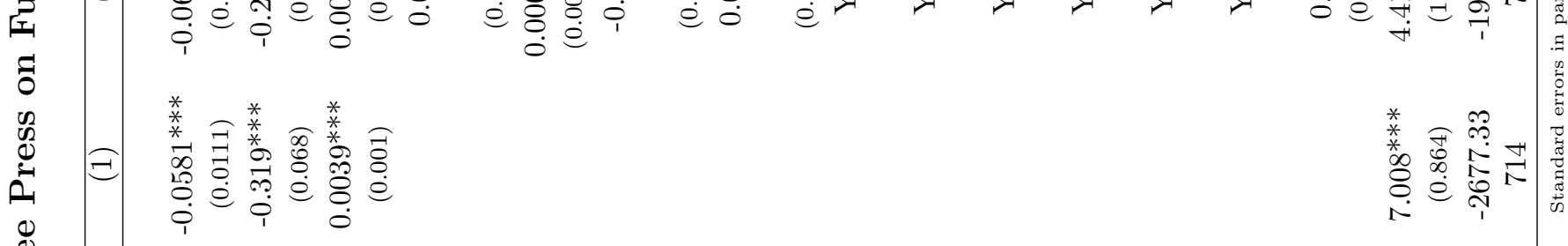

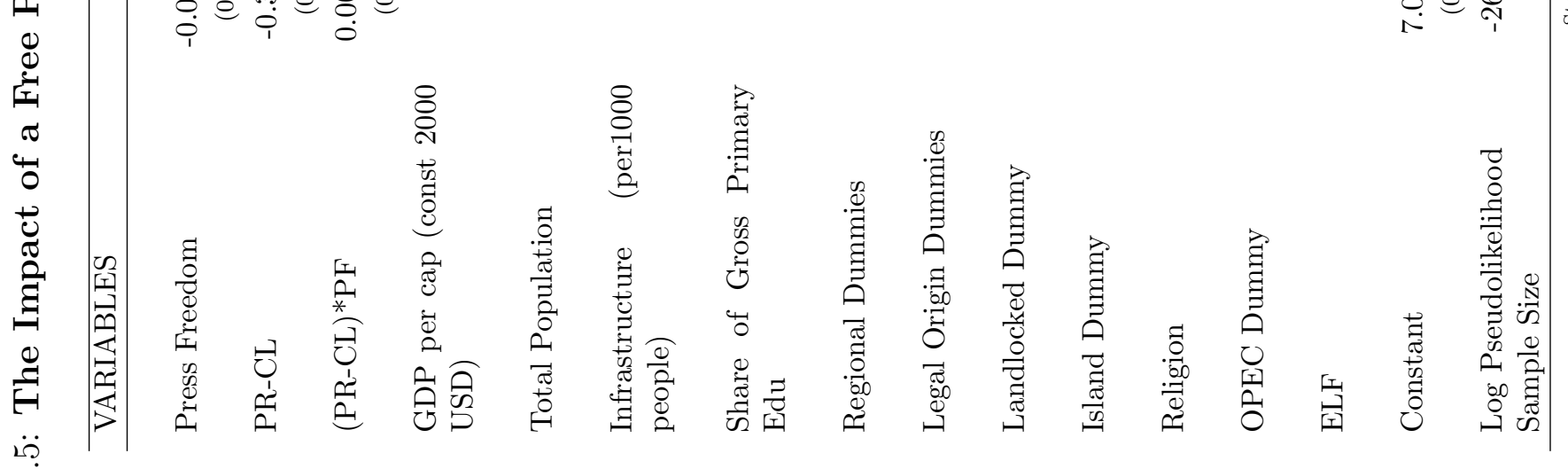

$$
\begin{aligned}
& \text { s } \\
& \text { 产 }
\end{aligned}
$$


Table 3.6: The Impact of a Free Press on Future Incidents of Terrorism, Cross Section

\begin{tabular}{|c|c|c|c|c|}
\hline VARIABLES & $(1)$ & $(2)$ & $(3)$ & $(4)$ \\
\hline Press Freedom & $\begin{array}{c}-0.0115^{*} \\
(0.0065)\end{array}$ & $\begin{array}{c}-0.0233^{* * *} \\
(0.0082)\end{array}$ & $\begin{array}{c}-0.0294^{* * *} \\
(0.0090)\end{array}$ & $\begin{array}{c}-0.0286^{* * *} \\
(0.0095)\end{array}$ \\
\hline $\begin{array}{l}\text { GDP per cap (const } 2000 \\
\text { USD) }\end{array}$ & & 0.0621 & -0.0069 & -0.0142 \\
\hline Total Population & & $\begin{array}{c}(0.0437) \\
0.000003^{*} \\
(0.000002)\end{array}$ & $\begin{array}{c}(0.0497) \\
0.000001 \\
(0.000001)\end{array}$ & $\begin{array}{c}(0.0497) \\
0.000001 \\
(0.000001)\end{array}$ \\
\hline $\begin{array}{l}\text { Infrastructure } \quad \text { (per1000 } \\
\text { people) }\end{array}$ & & $\begin{array}{l}-0.0184 \\
(0.0184)\end{array}$ & $(0.0277)$ & $(0.0285)$ \\
\hline $\begin{array}{l}\text { Share of Gross Primary } \\
\text { Edu }\end{array}$ & & $\begin{array}{c}0.0187^{* *} \\
(0.008)\end{array}$ & $\begin{array}{r}0.0135^{*} \\
(0.008)\end{array}$ & $\begin{array}{r}0.0130^{*} \\
(0.007)\end{array}$ \\
\hline Regional Dummies & & & YES & YES \\
\hline Legal Origin Dummies & & & YES & YES \\
\hline Landlocked Dummy & & & YES & YES \\
\hline Island Dummy & & & YES & YES \\
\hline Religion & & & YES & YES \\
\hline OPEC Dummy & & & YES & YES \\
\hline ELF & & & & $\begin{array}{l}-0.288 \\
(0.471)\end{array}$ \\
\hline Constant & $\begin{array}{c}3.124^{* * *} \\
(0.396)\end{array}$ & $\begin{array}{c}1.477^{* * *} \\
(0.679)\end{array}$ & $\begin{array}{l}0.206 \\
(0.916)\end{array}$ & $\begin{array}{l}0.166 \\
(0.876)\end{array}$ \\
\hline $\begin{array}{l}\text { Log Pseudolikelihood } \\
\text { Sample Size }\end{array}$ & $\begin{array}{c}-421.61 \\
119\end{array}$ & $\begin{array}{c}-388.98 \\
119\end{array}$ & $\begin{array}{c}-359.63 \\
119\end{array}$ & $\begin{array}{c}-351.52 \\
119\end{array}$ \\
\hline
\end{tabular}




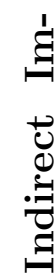

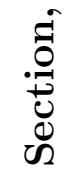

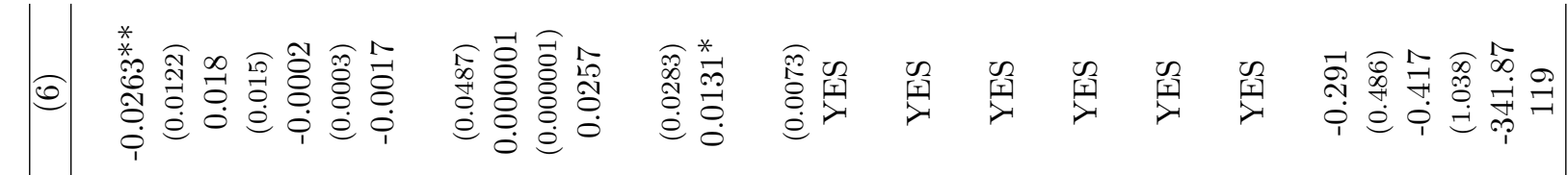

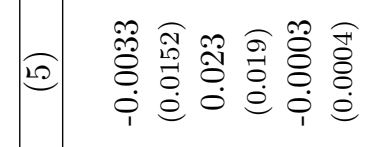

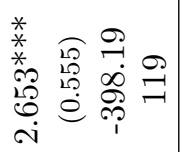

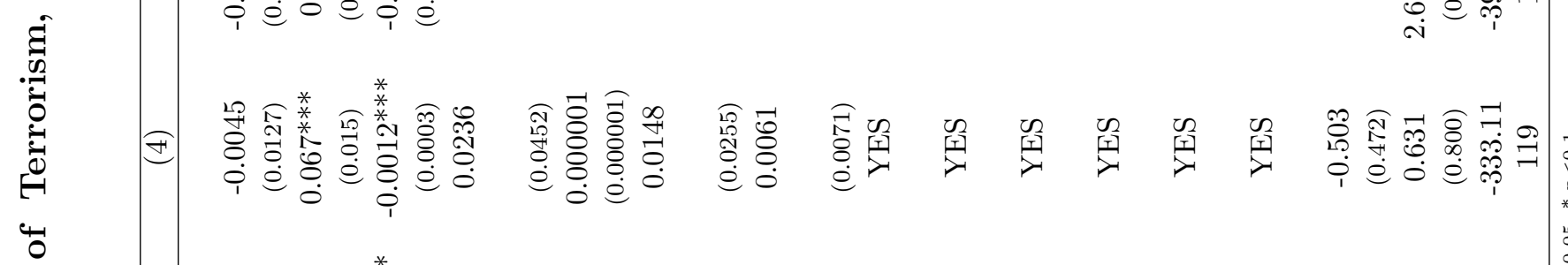

告

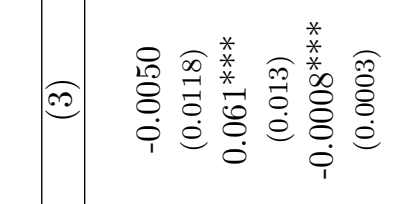

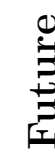

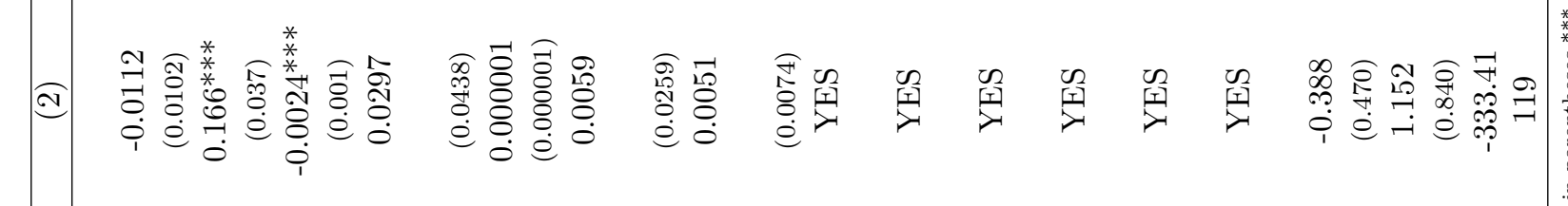

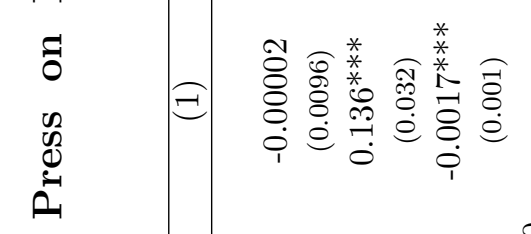

㣢

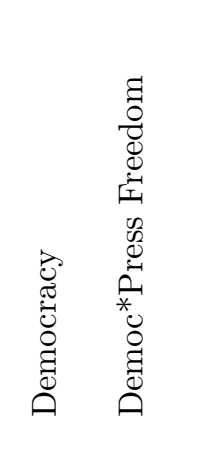

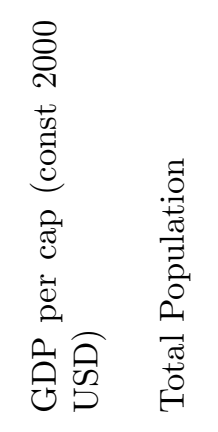

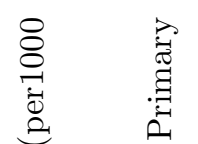

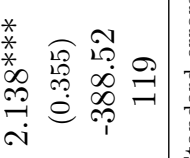

|

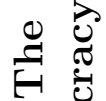

$\ddot{\sim}$

ले

$\frac{0}{0} \stackrel{0}{0}$ 


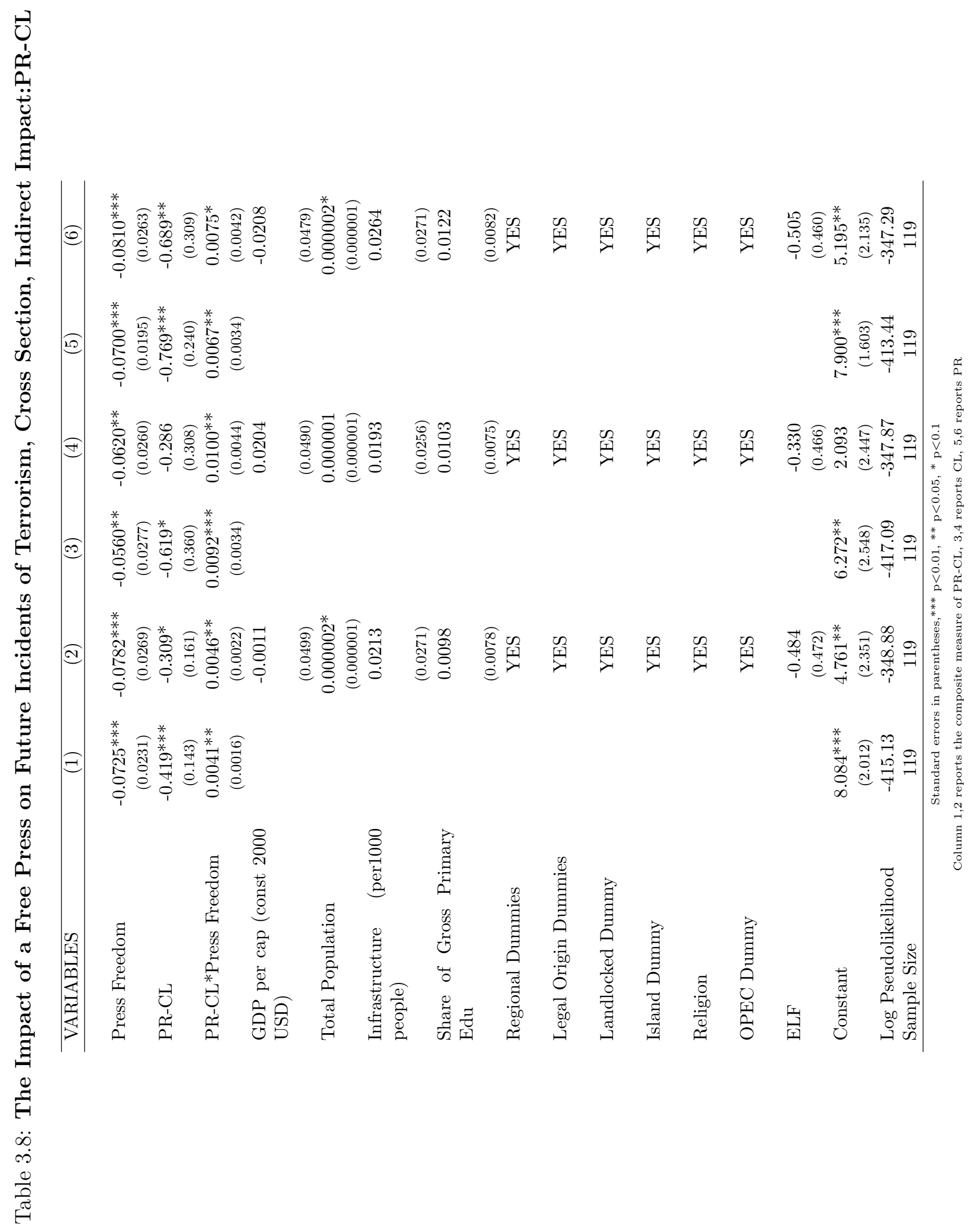


Table 3.9: List of Countries

\begin{tabular}{|l|l|l|}
\hline Albania & Ethiopia & Nigeria \\
\hline Algeria & France & Pakistan \\
\hline Argentina & Ghana & Peru \\
\hline Armenia & Greece & Philippines \\
\hline Australia & Guatemala & Poland \\
\hline Austria & Guinea & Romania \\
\hline Azerbaijan & Guyana & Russia \\
\hline Bahrain & Haiti & Rwanda \\
\hline Bangladesh & Honduras & Saudi Arabia \\
\hline Belarus & Hungary & Senegal \\
\hline Belgium & India & Sierra Leone \\
\hline Benin & Indonesia & Somalia \\
\hline Bolivia & Ireland & South Africa \\
\hline Bosnia-Herzegovina & Israel & South Korea \\
\hline Botswana & Italy & Spain \\
\hline Brazil & Jamaica & Sri Lanka \\
\hline Bulgaria & Japan & Sudan \\
\hline Burundi & Jordan & Sweden \\
\hline Cambodia & Kenya & Switzerland \\
\hline Cameroon & Kuwait & Syria \\
\hline Canada & Laos & Tajikistan \\
\hline Chad & Latvia & Tanzania \\
\hline Chile & Lebanon & Thailand \\
\hline China & Liberia & Togo \\
\hline Colombia & Lithuania & Trinidad and Tobago \\
\hline Costa Rica & Macedonia & Tunisia \\
\hline Cote D' Ivoire & Malaysia & Turkey \\
\hline Croatia & Mali & Uganda \\
\hline Cuba & Mauritania & Ukraine \\
\hline Cyprus & Mexico & United Kingdom \\
\hline Czech Rep. & Morocco & United States \\
\hline Dem. Rep. Congo & Mozambique & Uruguay \\
\hline Denmark & Myanmar & Uzbekistan \\
\hline Djibouti & Namibia & Venezuela \\
\hline Dominican Rep. & Nepal & Vietnam \\
\hline Ecuador & Netherlands & Yemen \\
\hline Egypt & New Zealand & Zambia \\
\hline El Salvador & Nicaragua & Zimbabwe \\
\hline Estonia & Niger & \\
\hline
\end{tabular}


Table 3.10: Summary Statistics

\begin{tabular}{|l|r|r|r|r|}
\hline \multicolumn{1}{|c|}{ Variables } & \multicolumn{1}{c|}{ Mean } & Standard Dev. & \multicolumn{1}{c|}{ Minimum } & Maximum \\
\hline Total \# of Terrorist Incidents & 18.34 & 41.99 & 1 & 519 \\
\hline Press Freedom Index & & & & \\
\hline Democracy (VDI) & 17.00 & 13.06 & 0 & 43.22 \\
\hline • Competition & 40.94 & 23.46 & 0 & 70 \\
\hline • Participation & 33.59 & 19.19 & 0 & 67.47 \\
\hline Democracy (Polity IV Database) & 5.69 & 3.85 & 0 & 10 \\
\hline Political Rights & 3.64 & 2.14 & 1 & 7 \\
\hline Civil Liberty & 3.90 & 1.76 & 1 & 7 \\
\hline • Political Rights-Civil Liberty Combined & 7.54 & 3.83 & 2 & 14 \\
\hline GDP Per Capita & 8.18 & 8.97 & 0 & 34.83 \\
\hline Total Population (in billions) & 68565.44 & 186431.9 & 565.51 & 1288400 \\
\hline Ethnolinguistic Fractionalization Index & 0.45 & 0.27 & 0.003 & 0.922 \\
\hline Economic Freedom Index (Heritage) & 58.41 & 10.96 & 23.65 & 81.19 \\
\hline
\end{tabular}


Figure 3.1: Impact of levels of Press Freedom on Incidents of Terrorism (for given levels of democracy)

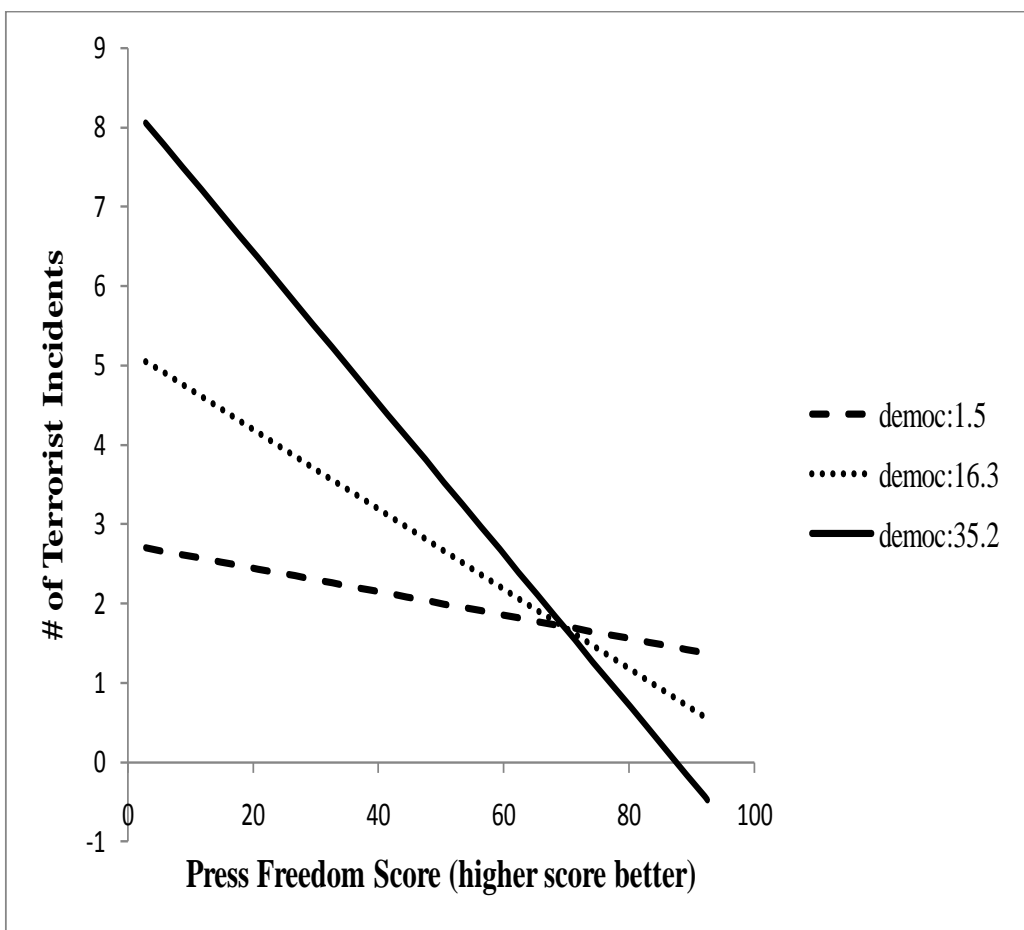


Figure 3.2: Scatter Plot of Raw Data: Level of Press Freedom and Number of Terrorism Incidents)

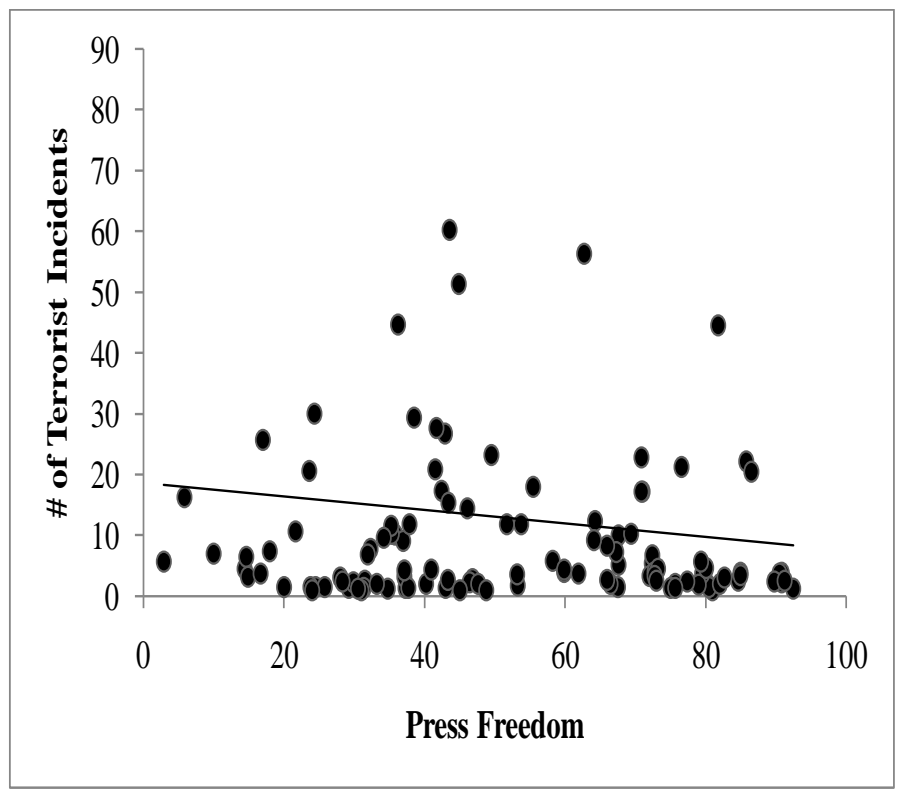




\section{Chapter 4}

\section{Counting on Financial Development for Urbanization}

\section{INTRODUCTION}

Urbanization, despite being a long studied concept, is yet to be explored comprehensively. The most interesting aspect of urbanization is that it gives rise to two very varied yet important consequences. While on one hand it gives rise to agglomeration benefits, it also generates social, environmental and administrative challenges like public sanitation problems, inadequate housing, traffic congestion and crime. While the agglomeration benefits of urbanization arises from and reinstates reduction in transaction costs, it also fosters exchange of ideas and technology thus enabling itself to protect local economies from sector-specific shocks. However, alongside these benefits that urbanization brings along, one cannot ignore its ill-effects. Rapid urbanization and concentration leads to an increase in the informal sector, raises urban poverty, increases urban slums, generates scarcity of resources like housing and other amenities thus spiraling urban real estate prices and leading to inadequate infrastructural facilities.

In wealthier nations, urban areas account for a greater share of national GDP than in less 
developed countries. Additionally, studies have documented how changes in urbanization levels reflect changes in the proportion of GDP generated by and the proportion of the workforce in industry and services. In other words, a country urbanizes as its economy and workforce become more centered on industry and services. In its 2008 report, the Commission on Growth and Development affirmed that no country has ever industrialized without also urbanizing. And another integral part of an industrialized economy is a sound financial system, especially well-functioning financial intermediaries or the banking sector. As mentioned earlier, urbanization is triggered by an attempt to reduce transaction cost. Well developed financial intermediaries reduce transaction costs too, thus furthering the goal of urbanization. This paper is an attempt to elaborate this idea of how financial development, especially with regards to financial intermediaries can impact urbanization outcomes in nations.

In what follows, we elaborate on the existing literature on urbanization and financial sector development in section 2. In section 3 we elaborate on the hypothesis, section 4 describes the data used to analyze the hypothesis empirically. In section 5 we provide a detail analysis of the raw data, while in section 6 we explain the results of our econometric analysis. Section 7 concludes.

\section{LITERATURE REVIEW}

Financial Development is an integral component of the growth process of an economy. Deepening of the sector promotes economic growth by mobilizing investment and lifting returns to financial resources, which in turn raises productivity. Development of financial intermediaries helps lower the cost of researching potential investors, exerting corporate controls, managing risk and mobilizing savings. The allocation function of institutions was first noted by Schumpeter (1934), who conjectured that bankers help to identify entrepreneurs with good growth prospects whereby helping to reallocate resources to their most productive 
uses. By providing such services to the economy, financial intermediation influences savings and allocation decisions in ways that has the potential to alter long run growth rates. The relationship between financial sector development and economic development has been extensively studied by Shaw (1973), Demetraides and Hussein (1996), Levine (1997), and Arestis et al. (2001), to name a few. According to Gallego et al. (2002), financial systems can develop efficiently in terms of financial depth captured by bank liquid liabilities to GDP. Schumpeter (1934), Rajan and Zingales (1998), Beck et al. (2000a), Hsu and Lin (2002), Bolbol et al. (2005), and Yu and Gan (2010) find support that banking sector development being positively related to short and long term economic growth.

Alexander Hamilton (1781) argued that "banks were the happiest engines that ever were invented" for creating economic growth. The indispensable role of financial system has been accepted by economists (King and Levine (1993a), King and Levine (1993b)). Levine (1997) re-established the importance of efficient financial markets during recent times. Development of the financial sector promotes growth and development of a nation through a variety of well established channels. Financial development can make foreign aid work better for aid recipient countries (Nkusu and Sayek (2004)). Further, Beck (2002) has proved that countries with an effective financial sector have a comparative advantage in manufacturing industries.

It is commonly agreed that a developed financial system promotes economic development by channelizing resources efficiently, mobilizing savings, reducing information asymmetry problems, facilitating trading, hedging, pooling and diversification of risk, aiding the exchange of goods and services and monitoring managers by exerting corporate control. In this paper we seek to identify an unexplored route through which financial development could affect growth, namely the development of urban centers. Levine et al. (2000) identifies that legal and accounting reforms that strengthen creditor rights, contract enforcement and accounting practices boost financial development and accelerates economic growth. Neusser and Kugler (1998) and Rousseau and Wachtel (1998) find that financial development Granger causes economic development in time series of growth and financial development. An inno- 
vative event study by Jayaratne and Strahan (1996) show that when individual states of the United States relaxed intra-state branching restrictions, the quality of bank loans increased and per capita GDP growth accelerated. A growth in size of financial intermediaries (both in terms of physical locations and total assets) enables it to be more efficient and hence offers a broader range of services to its customers (both lenders and borrowers). As noted by Rousseau and Wachtel (1998), the size of the intermediating sector reflects the volume of its services as also increases in the efficiency of their delivery. Their study also finds that a rapidly growing intermediation sector improves both resource allocation and economic performance. From the above discussion it is evident that while financial sector development is amply established to be a determinant of economic growth and development in general, it also has very important implications for the development of local economies.

Just like financial development is an important aspect of economic growth and development, so is urbanization. Urbanization is said to be the most important and enduring motive in stimulating consumption and investment. It also simultaneously propels economic and social development. Along with industrialization, urbanization also spurs social progress in education and key technologies. From the perspective of developmental history of countries around the world, urbanization is a logical choice for spurring economic and social development. The degree of urbanization is not merely an indicator of national strength and international competitiveness, but indeed a milestone of human progress itself.

Economic development and urbanization has a logical and inextricable linkage. The close connection between urban and national economic growth was recognized by Lucas (1988) and was inspired by the development of endogenous growth models. Urbanization is the consequence of changes in national output and composition from rural agricultural to urbanized modern manufacturing and services production. This process is a feature not only of the developing countries but can also be noted in peri-urban regions of developed countries. Urbanization promotes benefits from agglomeration such as localized information and knowledge spillovers and thus efficient urbanization promotes growth. Gallup et al. 
(1999) suggest that urbanization may 'cause' growth, rather than just emerge as a part of the growth process.

There is however limited evidence in this regard so as to make a firm assertion. Henderson (2004) too finds no evidence linking the extent of urbanization to either economic or productivity growth or levels. Ades and Glaeser (1995) on that other hand finds that urbanization has a negative impact on GDP per capita growth. They explain it by saying that large cities create rent seeking activities and instability instead of spurring long run growth. Moomaw and Shatter (1993) does not confirm to this finding. Their study, in fact, shows that the concentration of urban population in large cities is growth augmenting.

In the backdrop of the established importance of financial development and urbanization in their respective roles in inducing growth and development, we contribute by investigating if financial development can be a contributory factor determining the extent of urbanization itself. The results of the analysis would be a significant contribution to the literature as a study on this association has never been attempted before.

\section{HYPOTHESIS}

While urbanization is indispensible for the industrialization of a country and is needed for putting it on a trajectory of growth and development, too much or too rapid urbanization is not desirable. As Henderson (2004) notes, some degree of urbanization is desirable initially to reduce transaction costs and inter- and intra-regional expenditures. But unplanned and fast paced urbanization is associated with externalities such as congestion, pollution, overpopulation, etc. In fact, in developing countries the latter is the situation more often than not. Rapid urbanization in most developing countries in the past half century has been characterized by excessively high levels of concentration of the urban population in very large cities. Such large urban concentrations in developing economies, as noted earlier, are characterized by poor quality of life, health hazards and degrading environmental concerns. 
Henderson (2004) explains that developing countries face the negative impacts associated with urbanization more than that was faced by developed nations primarily due to the pace of urbanization in these developing economies. Developed countries, he observes, urbanized at a more "leisurely" pace. The United States was urbanized 70 percent in 1960 and 75+ percent in 1990. This gradual pace, combined with high GDP allowed time for the development of economic and political institutions conducive for sustaining an efficient form of urbanization and a reasonable quality of life. This stands in sharp contrast with the urbanization pace of developing nations which is not only much higher but also much less paced out. The latter, combined with weak economic and political institutions and lower GDP, make urban concentrations unsustainable. As Henderson notes, it is more like a "crash course, leaving little room for timely experimentation and adjustment". Given such situation, the main concern for countries, especially developing countries across the globe is to adopt policy measures so as to decongest the mega urban centers of its pressures and make them more sustainable. In this connection, we suggest that the development of the country's financial system, especially, financial intermediaries, would help alleviating overconcentration of cities and promote more orderly development and urbanization.

The financial development-urbanization nexus is a potentially untapped area of research. As mentioned earlier much work has concentrated on how financial development and urbanization are independently important for growth. A vast array of literature also looks into the various determinants of urbanization. However, no study has been done so far to see if financial sector development in itself can result in urban agglomeration. Given that urbanization contributes towards growth and development, it would be important to determine if urbanization is a channel through which financial development impacts the growth and development of a nation.

Becker (2006) studies the connection between city size and financial development mainly in the light of stock market development. He finds that city size is a robust determinant of stock market size and activity but not of other types of financial development (like banks) and 
that countries with large cities have a better developed stock market. Addressing the spatial nature of financial services, Parr and Budd (2000) note that organization and development of financial services have strong spatial dimensions that impact the urban system. Dehejia and Lleras-Muney (2005) look at the effect of state-level banking regulation on financial development and on components of state-level growth in the United States from 1900 to 1940. Though not the focus of the paper, yet a significant finding of the study reveals that financial development in the United States during 1900-1940 led to considerable bank branching whereon the various states went on to become more populous and more urban. They find that among 11 states that never adopted branching, 8 remained agricultural. This is evidence enough to look into the link between financial development and the process of urbanization, a fact not verified yet in the literature. Buckley et al. (2009) also note that a well developed financial market would complement a well functioning real estate market which in turn would strengthen the sustainability of the urban centers.

Earlier studies have looked into various factors that lead to urban agglomerations in a country. Moomaw and Shatter (1996) state that as economies develop, relative and absolute demand change in favor of industrialization. This is manifested through the growth of manufacturing and services sector, which tend to concentrate in urban centers. Further, internal economies of scale, localization benefits of urbanization and transportation costs raise the advantage of urban centers in terms of both production and consumption and hence promote further urbanization. Studies have emphasized that by virtue of increasing productivity, it is natural for urbanization to be accompanied by economic development. Bairoch (1988) and Todaro (1979) address an interesting character of urbanization in the context of developing nations. They argue that urbanization or growth of cities in developing nations are largely due to population explosion and artificially higher wage rates in cities as against only due to productivity rise as pointed by others. They consider urbanization in the developing world as mostly being "excessive". Wheaton and Shishido (1981) find a non-linear relation between urban concentration and GNP per capita. Their result show that 
urban concentration increases with increasing level of GNP per capita until a middle level of development. After that the relation becomes negative. Ades and Glaeser 1995) point out how government plays a role in determining the population of the largest city. They argue that government uses spatial tax policies to exploit the population. By applying favorable policies to bigger cities, the government enhances its own survival.

We contribute to the literature thus discussed above by considering if the initial level of financial sector development plays a contributory role in determining the pace of urbanization and urban concentration in countries. We hypothesize that the more developed the intermediary sector will be, the lower will the growth of urbanization and lower will be the rate of urban concentration. Therefore, when the financial intermediary sector is less developed, countries face agglomeration, but as the sector improves, the countries experience deconcentration. Our argument is based on the simple premise that a developed financial intermediary sector reduces transaction costs and brings in more transparency in the pricing mechanism of the market. This eases out locational constraints faced by individuals and businesses, enabling them to decentralize their activities. This also complements the fact that urbanization itself is triggered by the necessity to reduce transaction costs. Hence when the banking sector develops, people find it easier to carry on their economic functions without having to stay in the city center. When a higher level of financial development is reached, a process of suburbanization begins. This is mainly because, when countries embark on their process of financial sector improvement, it gets initiated in more populous places first. This in turn makes those populous centers more attractive for other businesses and draws more people from other parts of the country in search of better and more opportunities. However, once a moderate level of financial sector development is attained, spillover effects occur. The spillovers are in terms of the spread of a developed financial market all over the country and not just at specific urban centers. When such a stage is reached, it is no longer needed for businesses and the populace to flock only into cities to reap the benefits of a developed financial sector. It is then that the impact of financial sector development on urbanization 
starts showing a decline.

\section{DATA}

The paper uses a cross country framework to look into the implication of financial development on urbanization. The analysis considers 117 developed and developing countries (enlisted in Table 4.5) over the period 1975 to 2005.

The share of liquid-liability to GDP is chosen as the proxy to address development of financial intermediaries, the independent variable of interest. Liquid Liability as a share of GDP (LLY henceforth) is a traditional measure of financial sector development. It is the liquid liabilities of the financial system and is currency plus demand and interest-bearing liabilities of financial intermediaries and nonbank financial intermediaries as a percentage of GDP. This is the broadest available indicator of financial intermediation, since it includes all three financial sectors (central bank, commercial bank and other financial institutions). It is a typical measure of financial "depth" and thus of the overall size of the financial sector without distinguishing between the financial sectors or between the use of liabilities ${ }^{1}$. It indicates the degree of monetisation with respect to the real economy.

As observed by Beck et al. (2002) there exists very wide variation in this indicator. On one extreme there are countries with trillions of USD such as Japan and the U.S, on the other extreme there are small and poor countries with financial systems smaller than the size of one small bank in developed countries. The general consensus is that higher values of this indicator are associated with higher levels of financial development. The data for financial development has been taken from the financial database compiled by Beck et al. (2002). This database is the most comprehensive database available on various indicators addressing the different aspects of a financial sector and is extensively used in the literature. The choice of this proxy for a developed financial sector (with regards to its role of intermediation) finds

\footnotetext{
${ }^{1}$ We acknowledge the fact that there are other proxies that capture the development of the financial intermediary sector. But we have not included them in our study because the alternative variables are weakly correlated with LLY showing that the proxies do not capture the same aspect.
} 
ample support in previous literature. It has been persistently used as a measure the size of the financial intermediaries in seminal researches by King and Levine (1993a), Levine (1997), Levine et al. (2000), Benhabib and Spiegel (2000) and is always used in current literature addressing financial sector development and its various economic impacts.

The dependent variable of interest, urbanization, has been proxied in multiple ways. This includes measures that capture both extent of urbanization as well as the extent of urban concentration. For capturing the extent of urbanization, the most common measure the share of urban population relative to total population has been used. While this measure captures the general state of urbanization in an economy, other measures focus on urban concentration and look at the pressure on larger urban centers compared to the total urban population. To account for urban concentration, three alternate measures commonly used in the literature have been used. The first measure of urban concentration is the Hirschman-Herfindahl index of concentration, which is constructed by squaring the share of population apportioned to each city in the national urban population and summing those squares Wheaton and Shishido (1981). The second measure is the relative urban primacy which is the share of population contained in largest city in a national urban population Ades and Glaeser (1995). The third measure of urban concentration is urban gigantism which is the share of population contained in a country's largest city relative to its total population Gustavsson (1999); Moomaw and Alwosabi (2007)).

At the outset, it should be emphasized that the four measures of urbanization capture different aspects of the same. While the proportion of urban population relative to total population indicates how much of the population in a country is located in urban areas, the relative urban primacy and the Hirschman-Herfindahl (HF) indices capture how much of the existing urban population is concentrated in the bigger cities. Urban gigantism, on the other hand, captures exclusively how much of the total population of a country is concentrated in the largest city of the same. Given the different implications of these alternative measures of urbanization, it would not be prudent to expect financial development to have identical 
implication across board.

The data for urban percentage, relative urban primacy and urban gigantism is from the World Development Indicators database (WDI,2007). The Hirschman-Herfindahl index is constructed based on data from World Urbanization Prospects, 20072. The World Urbanization Prospects defines urban agglomeration as the de facto population contained within the contours of a contiguous territory inhabited at urban density levels without regard to administrative boundaries. It usually incorporates the population in a city or town plus that in the sub-urban areas lying outside of but being adjacent to the city boundaries. The choice of dataset pertaining to each proxy of urbanization or urban concentration follows previous literature by Moomaw and Shatter (1996), Moomaw and Alwosabi (2007) and Henderson (2004).

Besides the main explanatory variable, we control for other parameters in our benchmark analysis. They are GDP per capita, export as a share of GDP, value added of the agricultural sector as a share of GDP, net inflow of FDI as a percentage of GDP. We also control for infrastructural condition in a country. Following Moomaw and Shatter (1996) and Moomaw and Alwosabi (2007), we control for communicative infrastructure in a country, namely, provision of telephone mainlines per 1000 people. The data for this is taken from (WDI,2007) database. Further, the analysis incorporates regional dummies to avoid region-specific bias in the results. Following standard World Bank classification, the regions controlled for in the analysis are East Asia and Pacific, Europe and Central Asia, Latin America and the Caribbean, Middle east and North Africa, South Asia and Sub-Saharan Africa.

The choice of the other control variables follows directly from Moomaw and Shatter (1996). They use GDP per capita and sector contributions to GDP as explanatory variables

\footnotetext{
${ }^{2}$ The World Urbanization Prospect considers population of urban agglomerations with 750,000 inhabitants or more. A drawback associated with using the measures of urban concentration is data restriction especially due to lack of data on population in the largest cities for many nations, especially the island countries. However, as noted by Moomaw and Alwosabi (2004), there is no other source that the data can be gathered from apart from the two sources used in this paper and hence the analysis needs to be carried on keeping in mind the missing data. For a similar reason Moomaw and Alwosabi (2004) uses 30 countries for their analysis.
} 
for urbanization. They argue that economic development would cause urbanization firstly because of the associated division of labor with market growth and development of communication and transportation and secondly due to a shift in sectoral importance away from agriculture towards industry. Following the same argument we incorporate the variables GDP per capita and value added of the agricultural sectors in our analysis.

FDI inflow as a percentage of GDP is included in the analysis as a potential explanator for the extent of urbanization. FDI directly causes industrialization and indirectly spurs entrepreneurial activities both of which leads to creation of urban centers in countries. FDI can also be a proxy for the extent of openness of an economy. In that context it can lead to creation of transportation nodes which generally occur primarily in urban centers and also lead to increased demand for marketing, financing and communication Mills and Songs (1979). Elizondo and Krugman (1998) however argues that more openness reduces size of large cities unlike a closed economy since the increased accessibility of industrial firms to international markets frees them from the necessity to be concentrated in any one urban center in particular. Share of export to GDP is incorporated as a measure of openness of a country (Moomaw and Shatter (1996)) as is expected to reduce urban concentration.

\section{EVIDENCE FROM RAW DATA}

Before proceeding with the econometric analysis, we do a detail investigation of the raw data. To begin with, we rank the countries first in terms of the proxy of financial development. The data reveals that developed countries have the higher values of liquid liability over GDP while the developing countries have lower score of the same. However, some developing nations like Malaysia, South Africa, and Singapore do have high scores of the financial development proxy as some developed countries like Iceland and New Zealand have low scores of the same. In a similar way we rank the countries according the scores of the urbanization proxies 3 too.

\footnotetext{
${ }^{3}$ The summary statistics for the whole sample and the sub-samples of developing and developed countries are given in Table 4.6.
} 
For the measure urban population as a share of total population as also for the other three proxies of urban concentration, it is mostly the developed countries that are ranked higher in terms of their situation in the initial year of the sample period. However, when ranked according to the growth rates of urbanization, the developing countries take precedence.

The above conclusions suggest that countries that start off with less developed financial intermediaries experience higher rates of urbanization and urban concentration. To explain this more clearly, we plot the simple correlation between the growth in different measures of urbanization and the initial level of financial development. In Figure 4.1 we consider the case of urban population relative to total population. In the horizontal axis we plot the values of the initial LLY of countries while on the vertical axis is plotted the growth of urbanization of the same $\AA^{4}$. The fitted quadratic trend line shows a clear downward slope, implying that in general if a country starts off with a high level of LLY, it shows a lower growth rate of urbanization. If the $\mathrm{x}-\mathrm{y}$ space would be divided into four quadrants, it is clearly visible that all the developed countries lie in the lower right corner of the graph showing high level of financial development and lower growth of urbanization. In Figure 4.2 we show the scatter plot for H-F index of urban concentration. For the entire sample the scatter plot does not show an clear trend in this case. When in Figure 4.3 we plot the growth of relative urban primacy we however get a U-shaped trend line implying that with higher levels of LLY, relative urban primacy declines up to a point but then increases. In Figure 4.4 we repeat the same for urban gigantism and here it shows a very distinct declining trend for the entire sample of developed and developing countries.

Now, to analyze the data further, we do the same for the subsamples of developing and developed countries separately. Figure 4.5 through 4.8 represent the scatter plots for the four alternative proxies of urbanization for the developing countries only while Figure 4.9 through 4.12 does the same for developed countries. The scatter plots reveal that for the subsample of developing countries, higher levels of financial development is unanimously associated

\footnotetext{
${ }^{4}$ We consider log of all variables for the purpose of the analysis.
} 
with low urbanization (or urban concentration). However, the case for the sub-sample of developed countries is interesting. Growth in urbanization for developed counties show a U-shaped relation, implying that up to a certain point, a high level of financial development is associated with lower growth of urbanization or deconcentration, but at very high levels of financial development, growth of urbanization and urban concentration goes up. This goes on to say that developed countries with very high levels of financial sector development

are primarily urban. Further, as noted by Ottens and Henk (1990) in the context of the Netherlands, this is a reiteration of the fact that with regards to high levels of financial development, developed countries are at a different phase of urbanization. He explains that while urbanization sets in a country, with development of various complementary factors (like economic growth, infrastructural development etc), an initial phase of urban concentration is followed by rapid urban deconcentration where countries successfully relocate their growing urban population in satellite cities. However, at very high levels of development with market forces in action, socio-cultural changes and new planning strategies, a new phase of urbanrevitalization sets in. This view is also reiterated by Antrop (2000) in the context of western European countries. In the next section we conduct econometric analysis to substantiate what the raw data reveals.

\section{EMPIRICAL RESULTS}

To test our hypothesis empirically, we perform a cross-section and pooled regression analysis. The cross-section analysis spans over the years 1975-2005 and the panel is constructed using 10 year intervals. Hence for the panel analysis, each country has three data points. As for the dependent variable, for cross-section, the growth in urbanization is calculated between 1975 and 2005, while for the 10-year panel analysis the growth in urbanization are considered for the periods between 1975 and 1985, 1985 and 1995 and 1995 and 2005. To account for any 
biasness due to potential outliers we engage in robust regression analysi:5. Our benchmark specifications are as follows:

$$
\begin{aligned}
& \text { GrowthinUrbanProxy }_{i t}=\alpha_{0}+\beta_{1} \text { InitialLevelofUrbanProx }_{i t}+\beta_{2} \text { InitialF }_{i t} \\
& +\beta_{3} \text { Dummy for DevelopedCountries } * \text { InitialF } D_{i t}+\beta_{4} X_{i t}+\varepsilon_{i t} \\
& \text { GrowthinUrbanProxy }_{i t}=\alpha_{0}+\beta_{1} \text { InitialLevelofUrbanProxy }_{i t}+\beta_{2} \text { InitialF }_{i t} \\
& +\beta_{3} \text { InitialF } D_{i t}^{2}+\beta_{4} \text { Dummy forDevelopedCountries } * \text { InitialF } D_{i t} \\
& +\beta_{5} \text { Dummy forDevelopedCountries } * \text { InitialF } D_{i t}^{2}+\beta_{6} X_{i t}+\varepsilon_{i t}
\end{aligned}
$$

Equations (4.1) and (4.2) are used for analyzing the entire sample of 117 countries for both cross section and panel analysis. The same equations are used for all four proxies of urbanization. GrowthinUrbanProxy $y_{i t}$ gauges the growth in the proxy of urbanization between the final and the initial year for country "i" at time "t". InitialLevelofUrbanProxy ${ }_{i t}$ refers to the initial level of the proxy of urbanization for country "i" at time "t" and InitialF $D_{i t}$ represents the initial level of financial development of country "i" at time "t". InitialF $D_{i t}^{2}$ refers to the square of the same. $X_{i t}$ is the vector of control variables pertaining to country "i" at time "t" and $\varepsilon_{i t}$ is the error term. For all the control variables, we consider the initial values and the logarithms of the same.

Tables (4.1) and (4.2) represent equations (4.1) and (4.2) for the cross-section of the entire sample. The results in table (4.1) reveal that across the alternative proxies of urbanization, a higher initial value of LLY is associated with a lower growth in urbanization even after controlling for all other economic and demographic factors. All the coefficients also have

\footnotetext{
${ }^{5}$ Robust regression is the best way of dealing with outliers. Since outliers are not data entry errors and hence there is no reason to exclude these data points from the analysis. In fact robust regression is the best alternative between deleting these points, and allowing them to violate the assumptions of OLS regression. However, for robustness, we have already use quantile regression technique that considers the median rather than the mean of the dependent variable. The results remain robust in both cases, confirming the robustness of the results.
} 
statistical significance. In the analysis, since a dummy has been used to account for developed countries, GDP per capita is not used separately. The analysis also reveals that higher initial values of the urban proxy also lead to lesser growth in urbanization.

As regards to the other coefficients, the interaction term for the initial level of LLY and the developed country dummy as also the developed country dummy itself have a positive coefficient, as expected. This reiterates the scatter plots for developed nations that revealed that very high values of LLY are associated with higher urban growth in developed nations. Further, as expected, higher share of exports to GDP has a positive coefficient implying that higher trade openness lead to higher urbanization, higher level of communication infrastructure have a negative coefficient (implying urban deconcentration) as does higher FDI inflows as a share of GDP. Higher contribution of the agricultural sector to GDP should mean a less industrialized economy and hence less urban. So we ideally expect a negative coefficient as is found for the proxies of urban population in relation to total population and urban gigantism. But for the H-F index of urban concentration and relative urban primacy the coefficient is positive. This can be explained that primarily agricultural economies typically have fewer big cities and hence as the economy develops, people and businesses typically flock into those cities.

The results in table (4.2) are similar. However the results do show that the square of LLY has a negative coefficient across all four proxies but has statistical significance only for the share of urban population and urban gigantism. Tables (4.3) and (4.4) repeat the same exercise but for the 10 year panel and the results are similar. In the panel analysis however, it is relative urban primacy and urban gigantism that has statistically significant coefficients with regards to the square of LLY in table (4.4). To check the presence of quadratic relation with regards to LLY, we check the specification for the sub-samples of developing and developed countries. For the developing countries the square of LLY has a negative and statistically significant coefficient across the four proxies. For the sub-sample of developed countries, LLY and the square of it have a positive and significant relation. 
To explain the results more clearly, as a representation, we plot the regression outcomes only for the first proxy of urbanization: share of urban population relative to total. This is depicted in Figure 4.13 through 4.16. In 4.13, we plot the specification for the whole sample pertaining to equation (4.2). It shows that as the level of initial LLY increases, the growth in urbanization declines, until a very high level of initial LLY is reached, whereby an upward trend sets in. Figure 4.14 plots the specification for the whole sample again, but now without the cross terms with the developed country dummies and we get a similar plot. In figure 4.15, we plot the regression outcome for the sub-sample of developing countries including the square of LLY. The plot shows a very distinct negative plot. This implies that the range of initial LLY that the sample of developing countries have, they face a declining urban growth or deconcetration. When the same plot is repeated in figure 4.16 for the sample of developed nations, the plot is upward sloping, as expected.

The detailed analysis reveals that a developed financial intermediary sector serves the purpose of deconcentrating urban locations. A well developed financial intermediary sector is associated with lower growth of urbanization and lower growth of urban concentration. The fact that the result are driven by the developing countries bear testimony to the fact that developing the financial intermediaries are a viable policy for the countries to ease out urban congestion and allow proper development of the same.

To check the robustness of the results, a number of alternatives are considered. Firstly, we check the appropriateness of the model by running diagnostic tests on its residuals. The tests are satisfied depicting the appropriateness of the model used. Next, we control for population density. This is done to acknowledge the fact that patterns of urbanization will be influenced by countries that already have high population density. the results remain robust to this inclusion. GDP per capita ${ }^{6}$ is included as a control for the living standard in a country $\square^{7}$ and the results remain economically and statistically unchanged. Further we

\footnotetext{
${ }^{6}$ Test for multicollinearity reveal that none of the VIF estimates are more than 10 implying that there is no problem of multicollinearity in the model.

${ }^{7}$ Ideally one should control for the level of income inequality in a country to account for urban agglomeration patterns. However, there is severe lack of data for the income inequality variable, proxied by the GINI
} 
use an alternative proxy for financial intermediation development, namely M2/M1. ? uses M2/M1 - the ratio of broad money to narrow money as a proxy for financial sophistication and links it to human capital and political stability. The paper emphasizes that the ratio of broad money to narrow money (M2/M1) should be positively related to a country's level of financial development. Savings deposits increases more rapidly than transaction balances as the financial system expands. Following that, the results are tested for our paper and they remain robust. The results are reported in Table 4.5 .

\section{CONCLUSION}

In this paper, we examine the extent to which the level of a country's financial development plays a contributory role in determining the pace of urbanization and urban concentration in different countries. We hypothesize that the more developed the financial sector will be, the lower will the growth of urbanization and urban concentration. Our argument is based on the premise that a developed financial intermediary sector reduces transaction costs, facilitates trading, and allows economic agents to diversify risks. This eases out locational constraints enabling individuals to decentralize their activities.

Using a sample of developed and developing countries over the period 1975 - 2005, the paper shows that a higher level of financial development is associated with a lower growth in urbanization and urban concentration. The empirical analysis also concludes that the latter result is mostly driven by the experience observed in developing countries.

Rapid urbanization in most developing countries in the past half century has been characterized by excessively high levels of concentration of the urban population in very large cities. Such large urban concentrations in developing economies are characterized by poor quality of life, health hazards and degrading environmental concerns. Urbanization is indispensable for the industrialization of a country, which in turn is needed for putting it on a trajectory of growth and development. However, too much or too rapid urbanization is not desirable. coefficient. The scarcity of this data reduces number of observations and are hence not included in the study 
Some degree of urbanization initially reduces transaction costs and inter- and intra-regional expenditures. But unplanned and fast paced urbanization is associated with externalities such as congestion, pollution, overpopulation, etc. As the banking sector develops, especially in developing in economies, economics agents will find it easier to carry out their economic functions with less dependence from the city center. 
Figure 4.1: Scatter plot for Whole sample for Share of Urban to Total Population

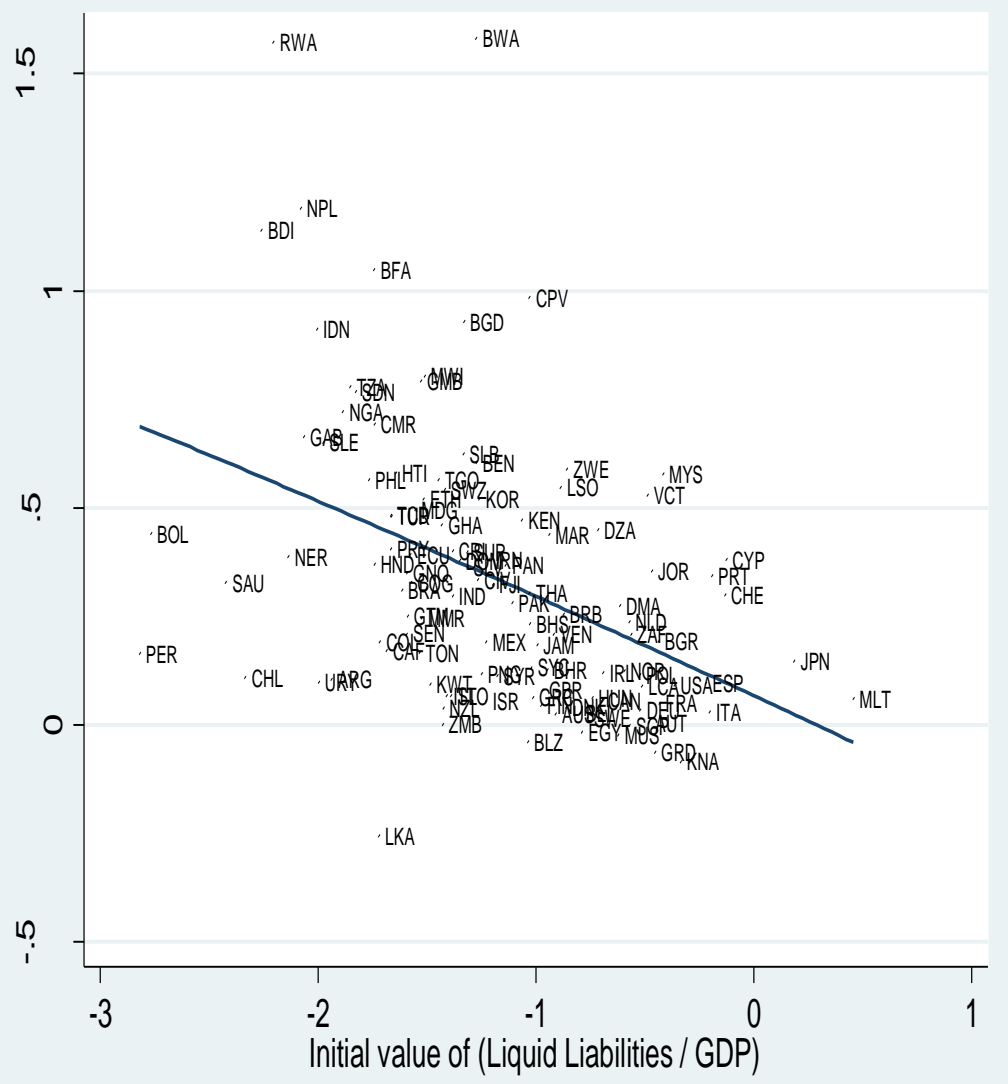


Figure 4.2: Scatter plot for Whole sample for H-F Index of Urban Concentration

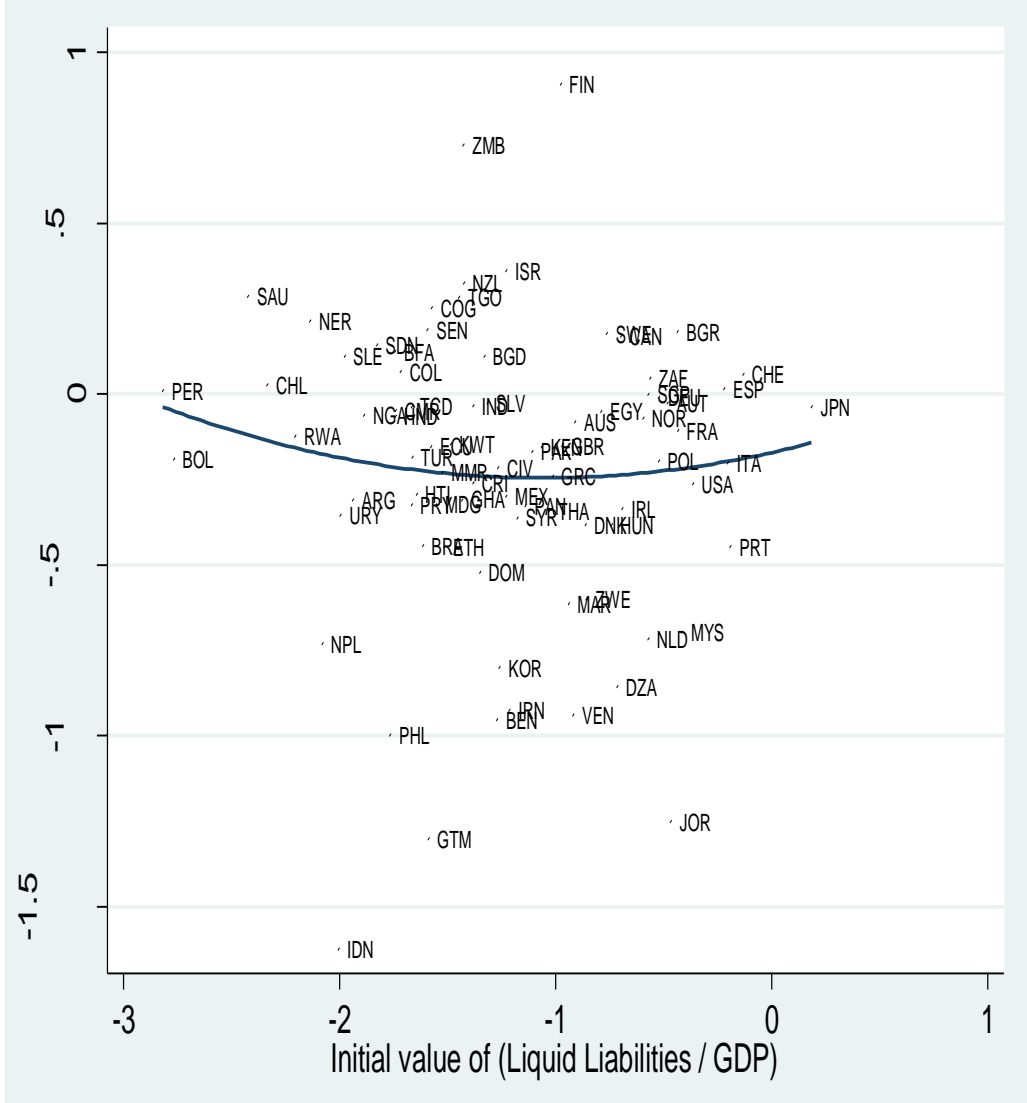


Figure 4.3: Scatter plot for Whole sample for Relative Urban Primacy

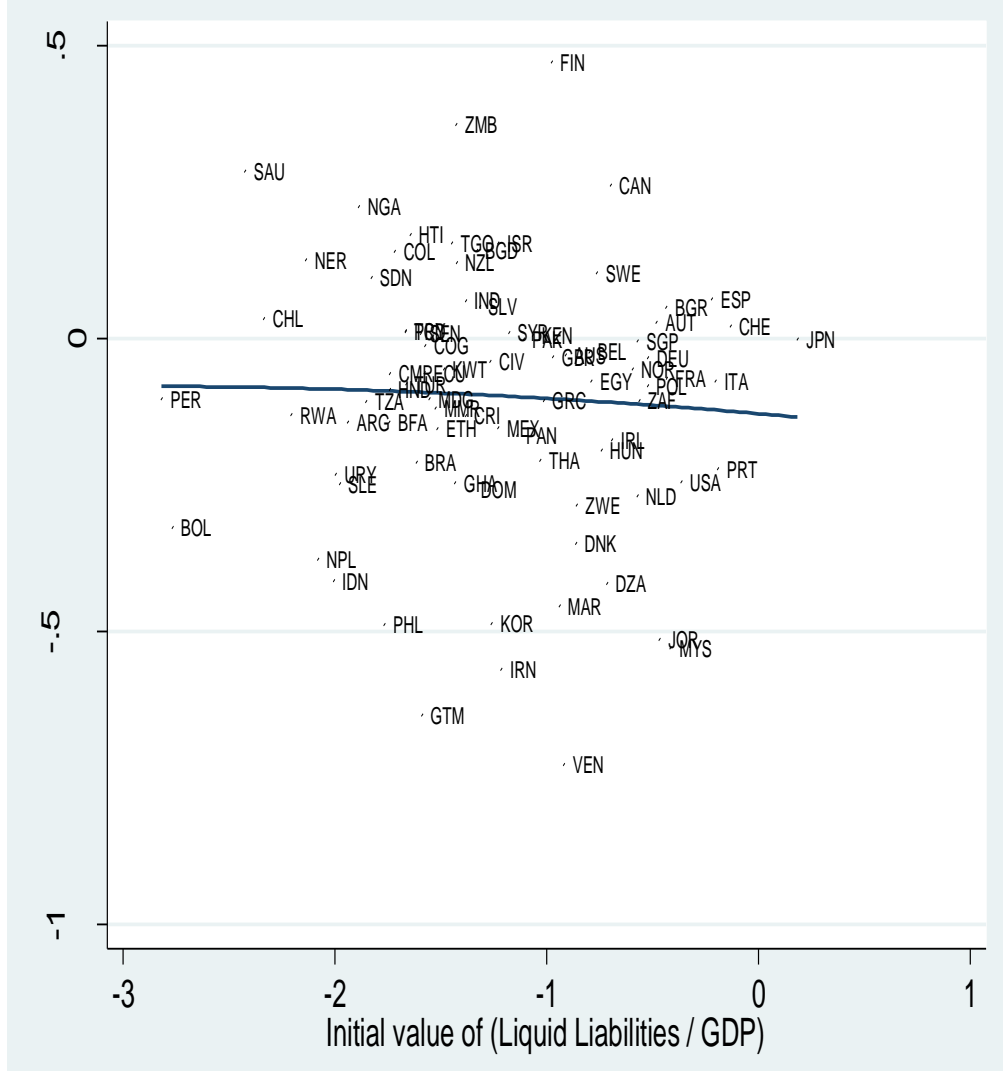


Figure 4.4: Scatter plot for Whole sample for Urban Gigantism

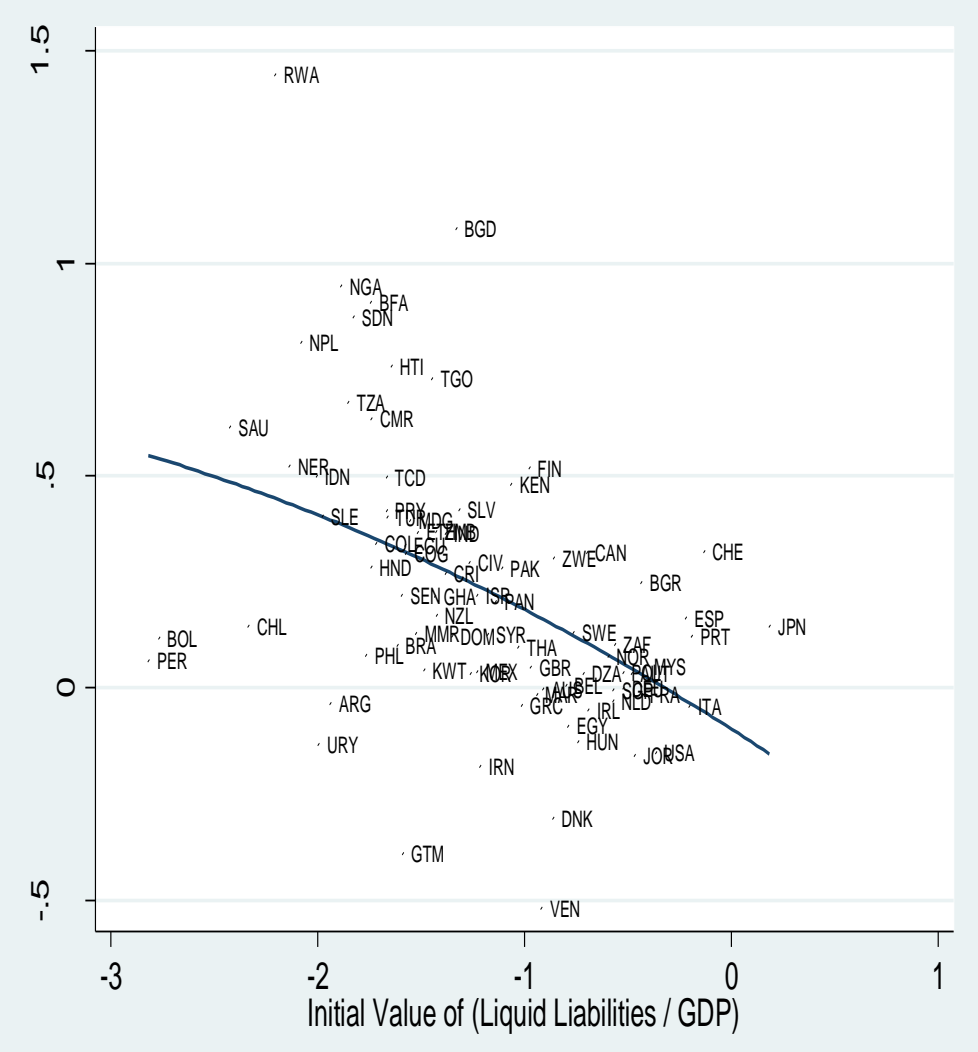


Figure 4.5: Scatter plot for Share of Urban to Total Population (Developing Subset)

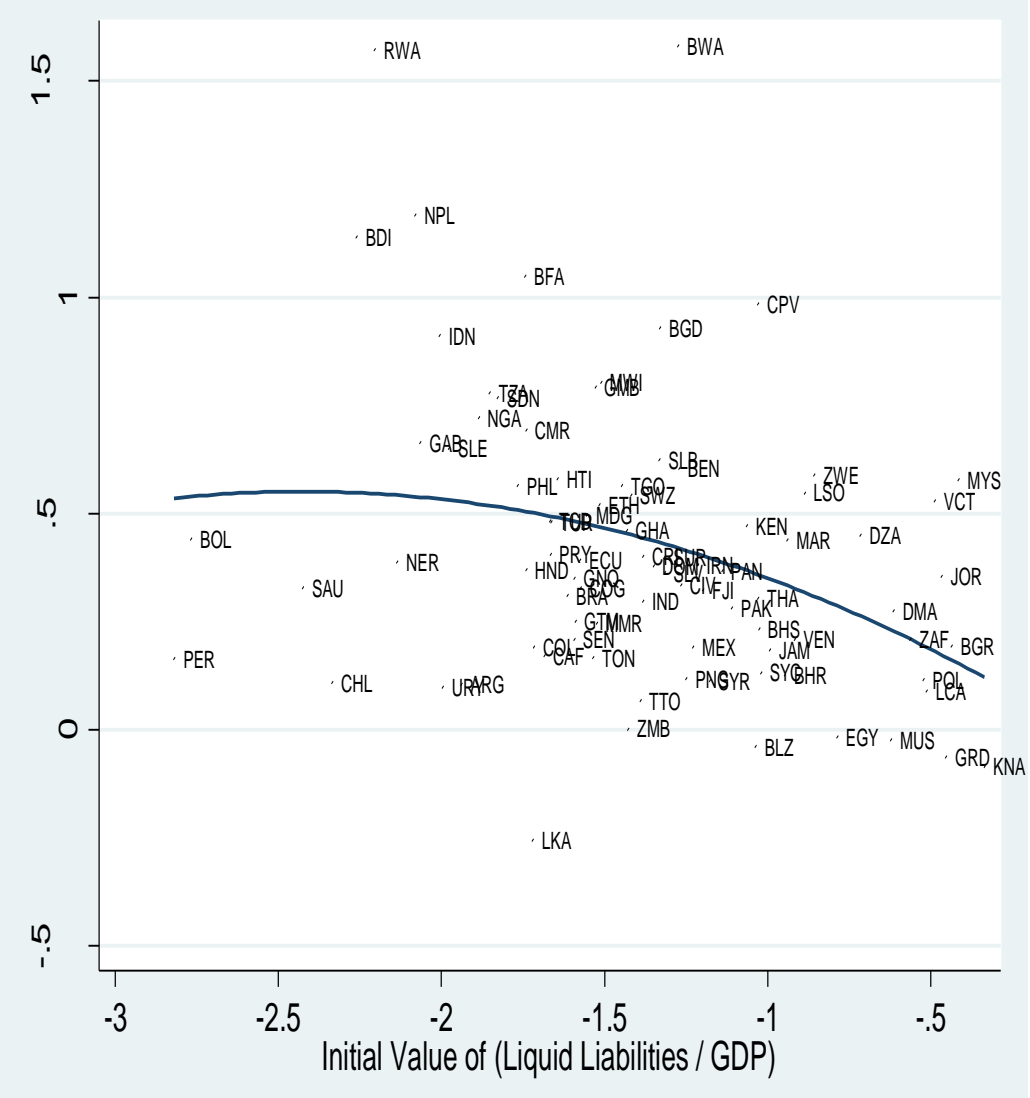


Figure 4.6: Scatter plot for Share of H-F Index of Urban Concentration (Developing Subset)

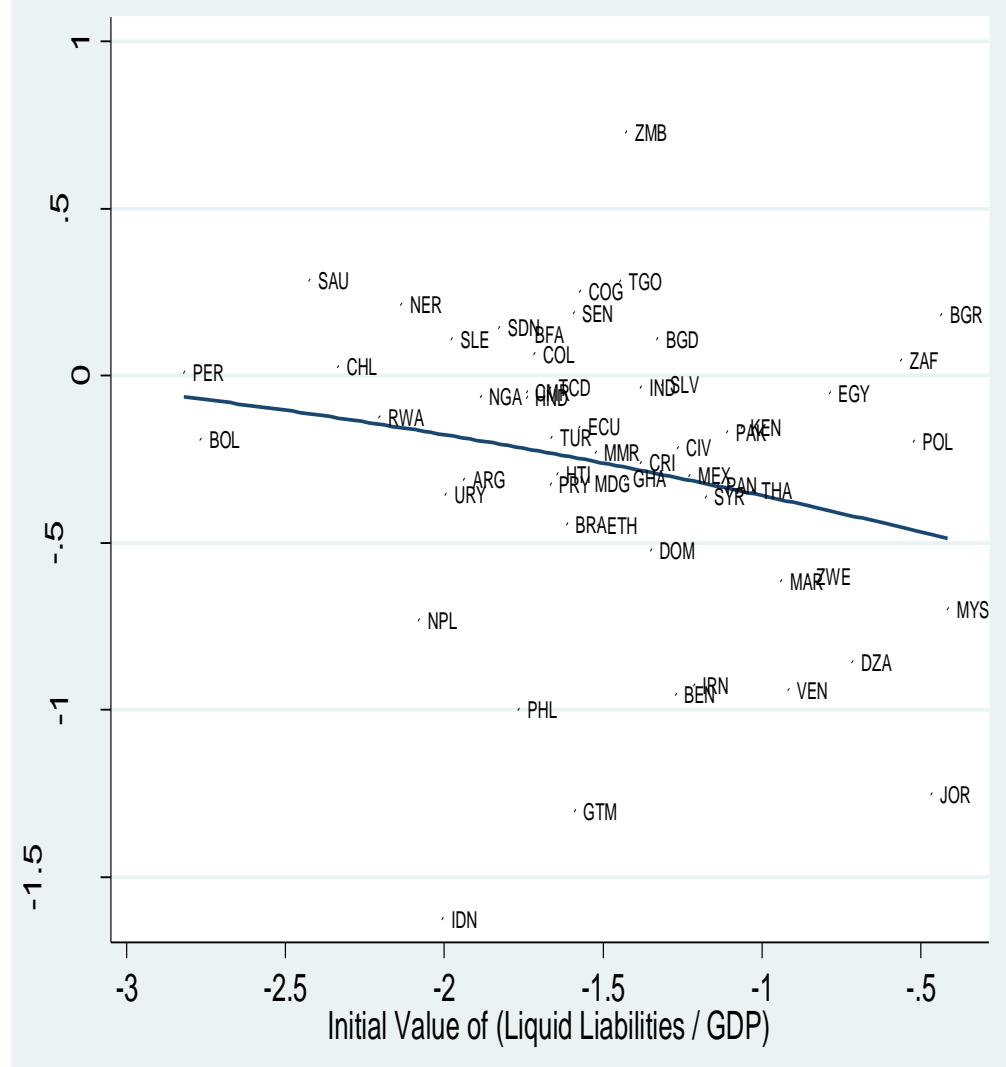


Figure 4.7: Scatter plot for Share of Relative Urban Primacy (Developing Subset)

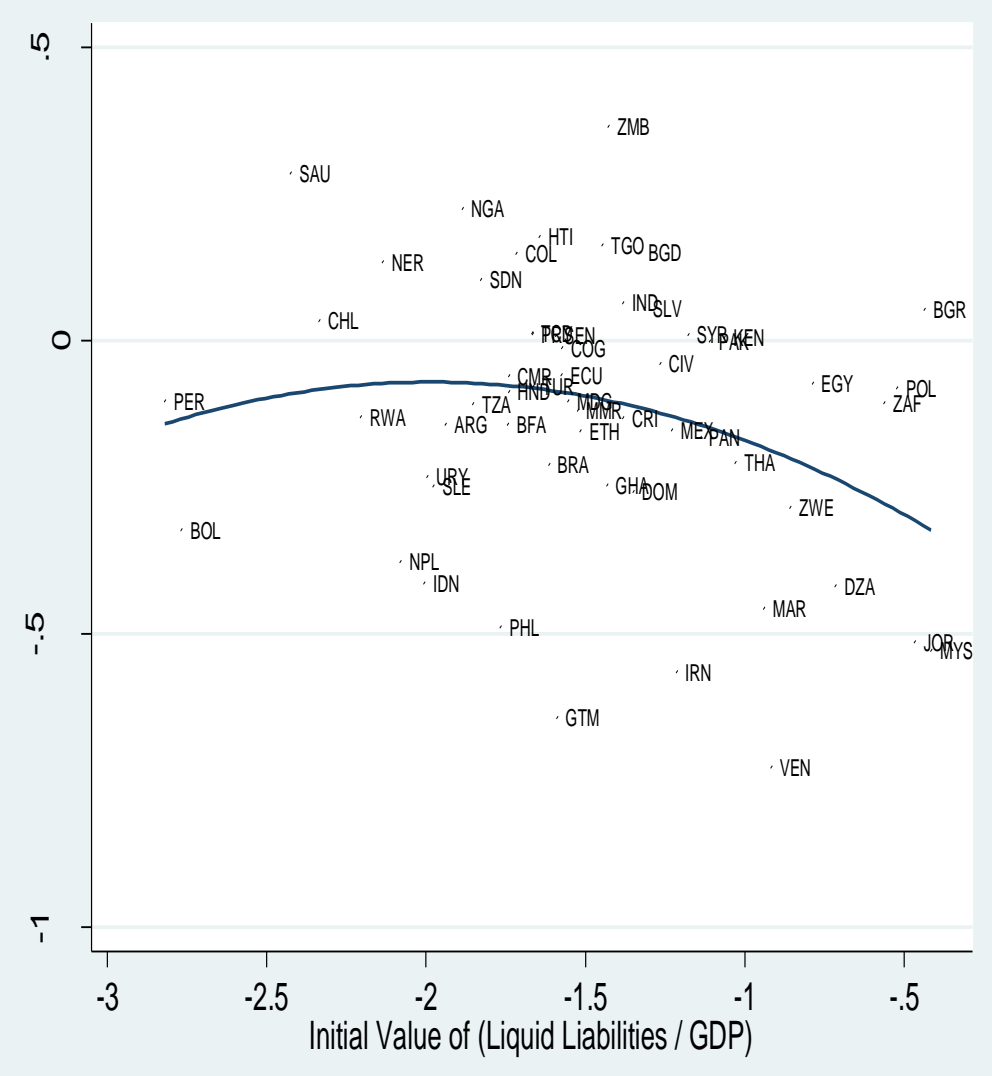


Figure 4.8: Scatter plot for Share of Urban Gigantism (Developing Subset)

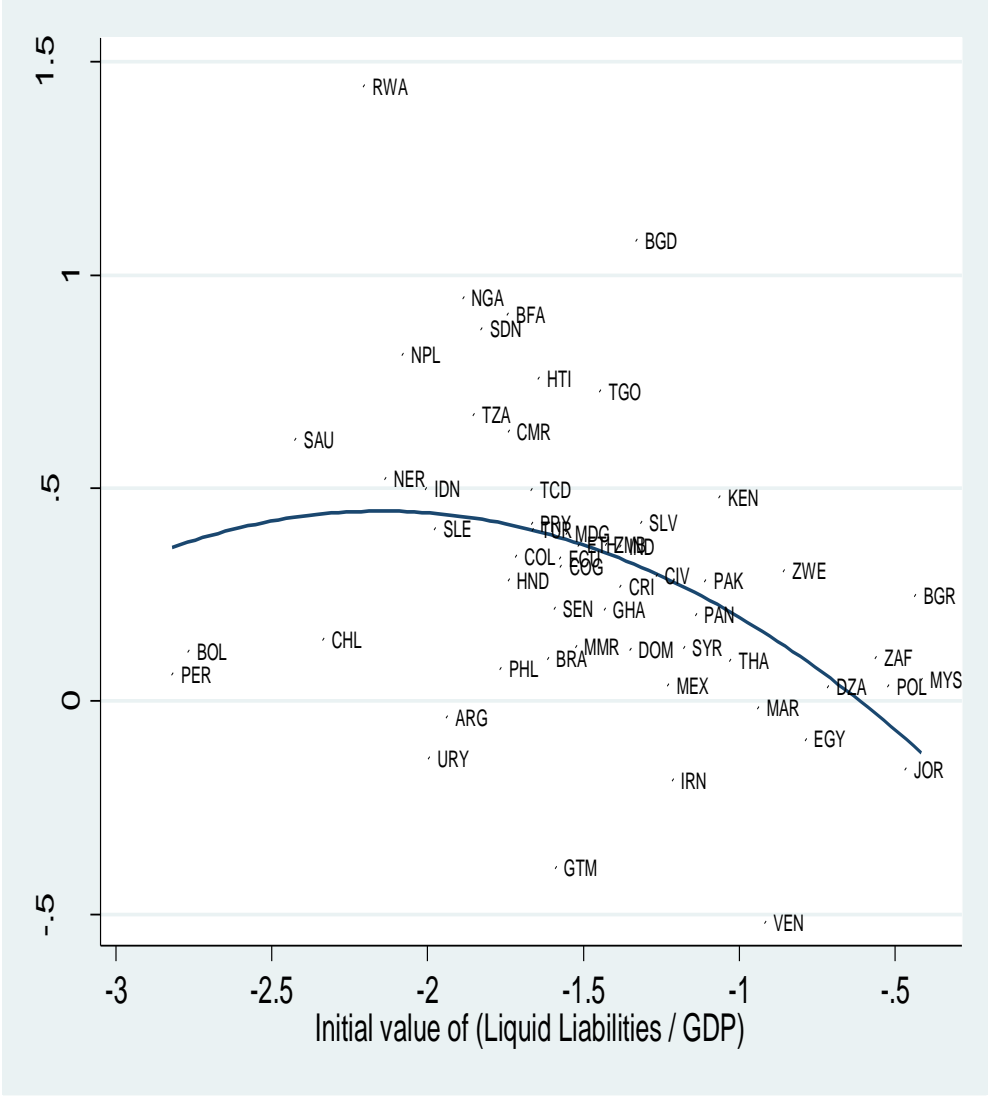


Figure 4.9: Scatter plot for Share of Urban to Total Population (Developed Subset)

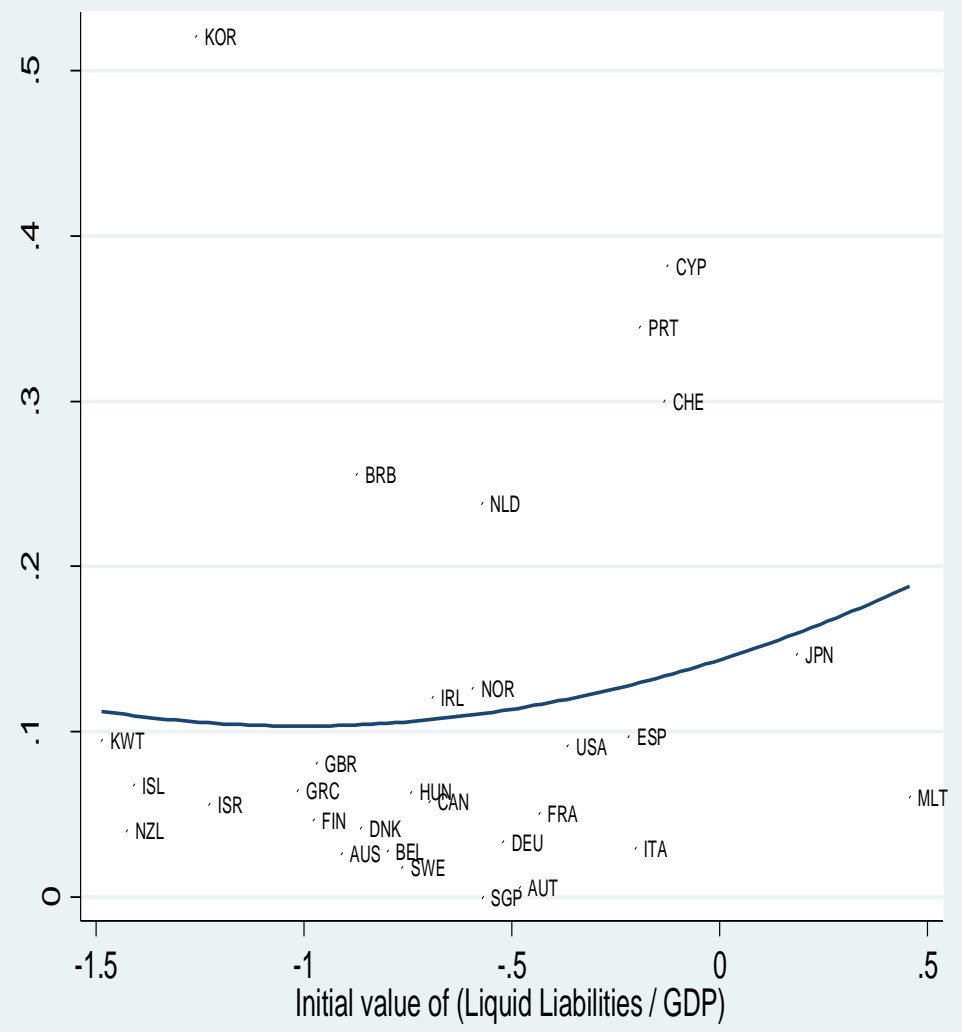


Figure 4.10: Scatter plot for Share of H-F Index of Urban Concentration (Developed Subset)

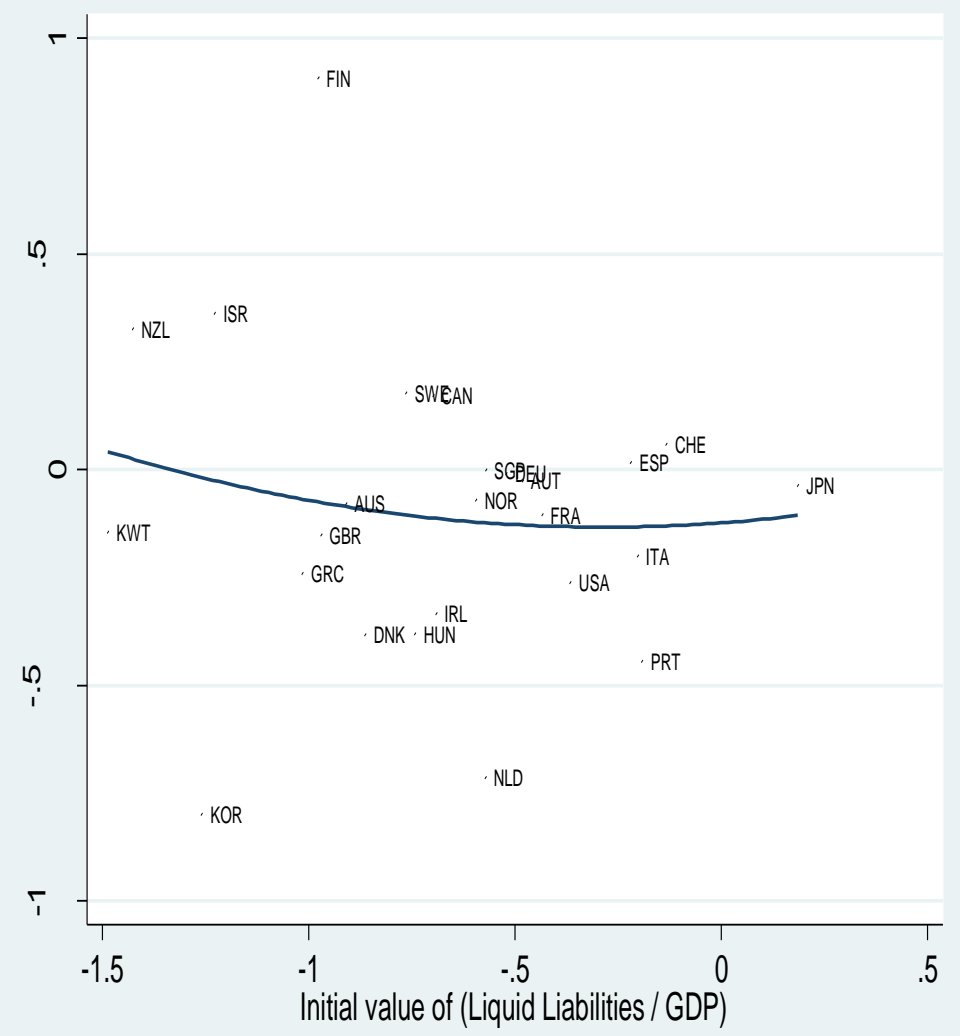


Figure 4.11: Scatter plot for Share of Relative Urban Primacy (Developed Subset)

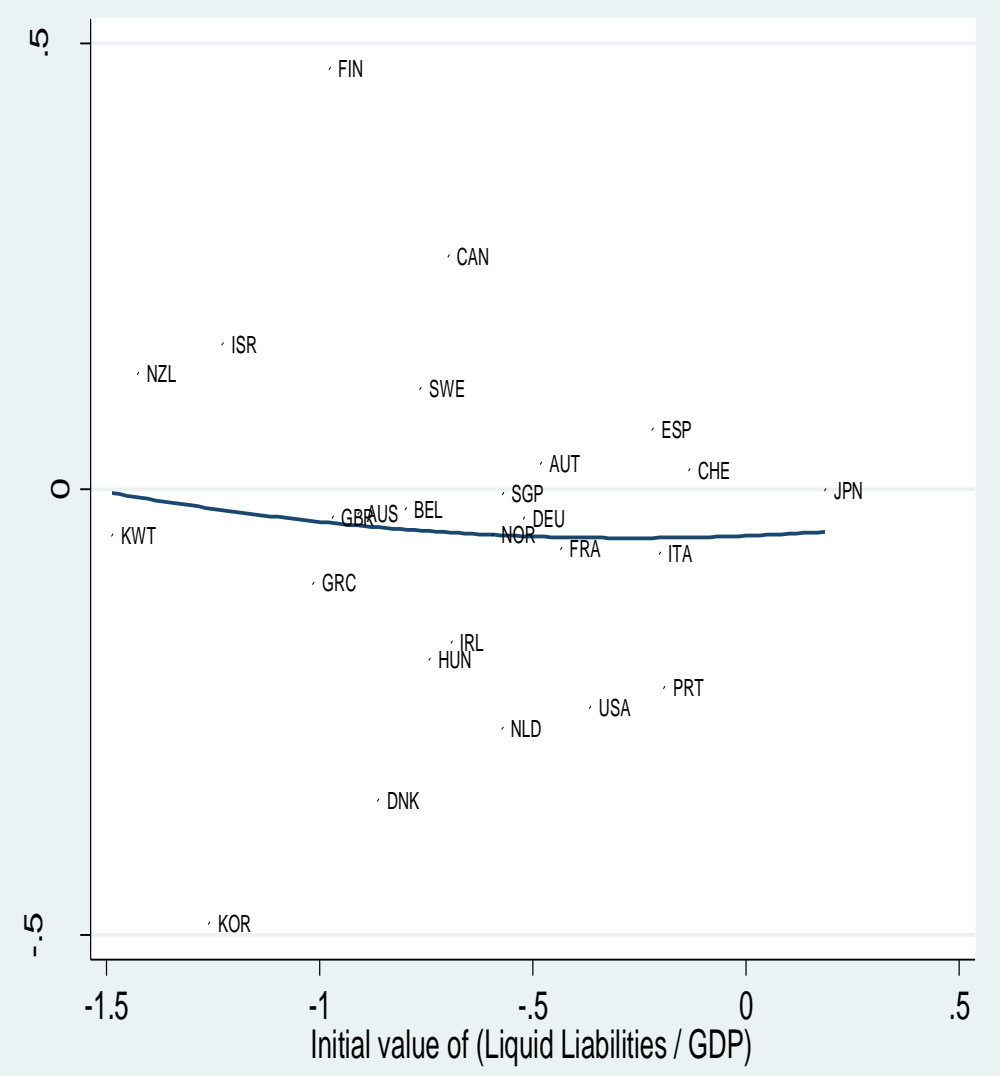


Figure 4.12: Scatter plot for Share of Urban Gigantism (Developed Subset)

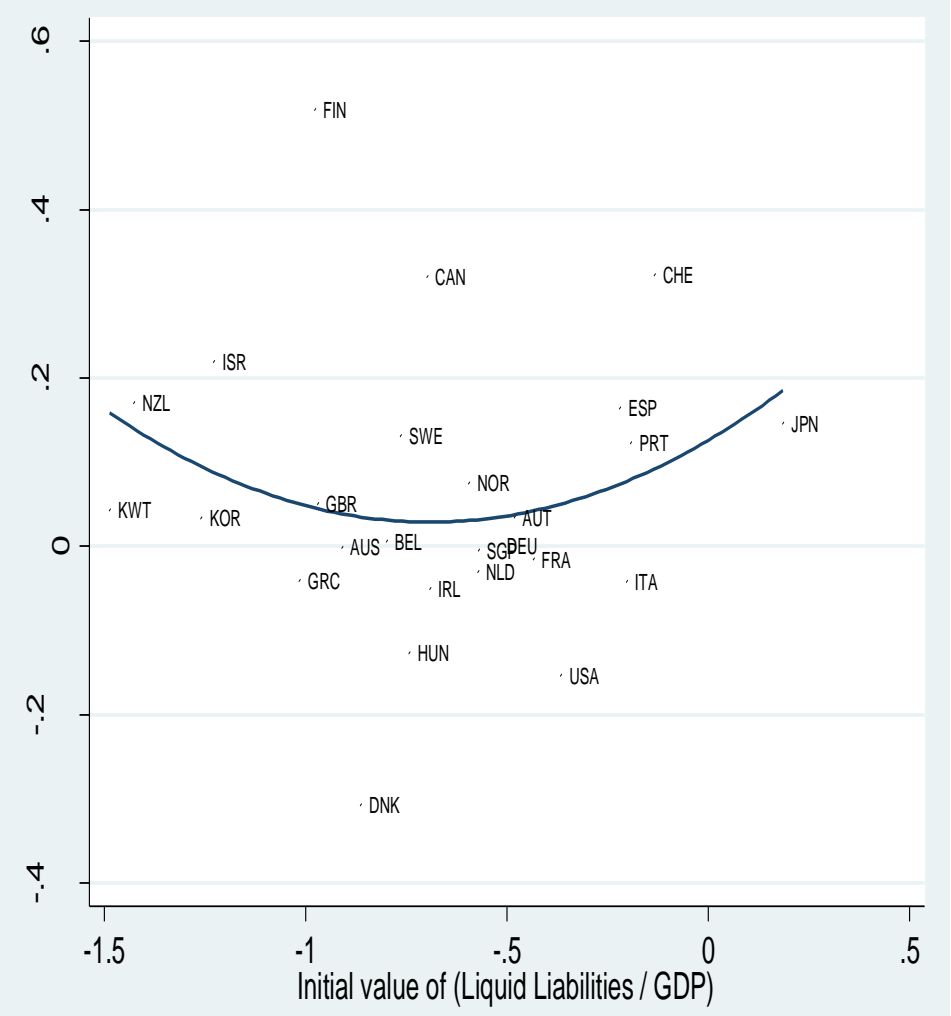


Figure 4.13: Fitted Graph for Whole Sample

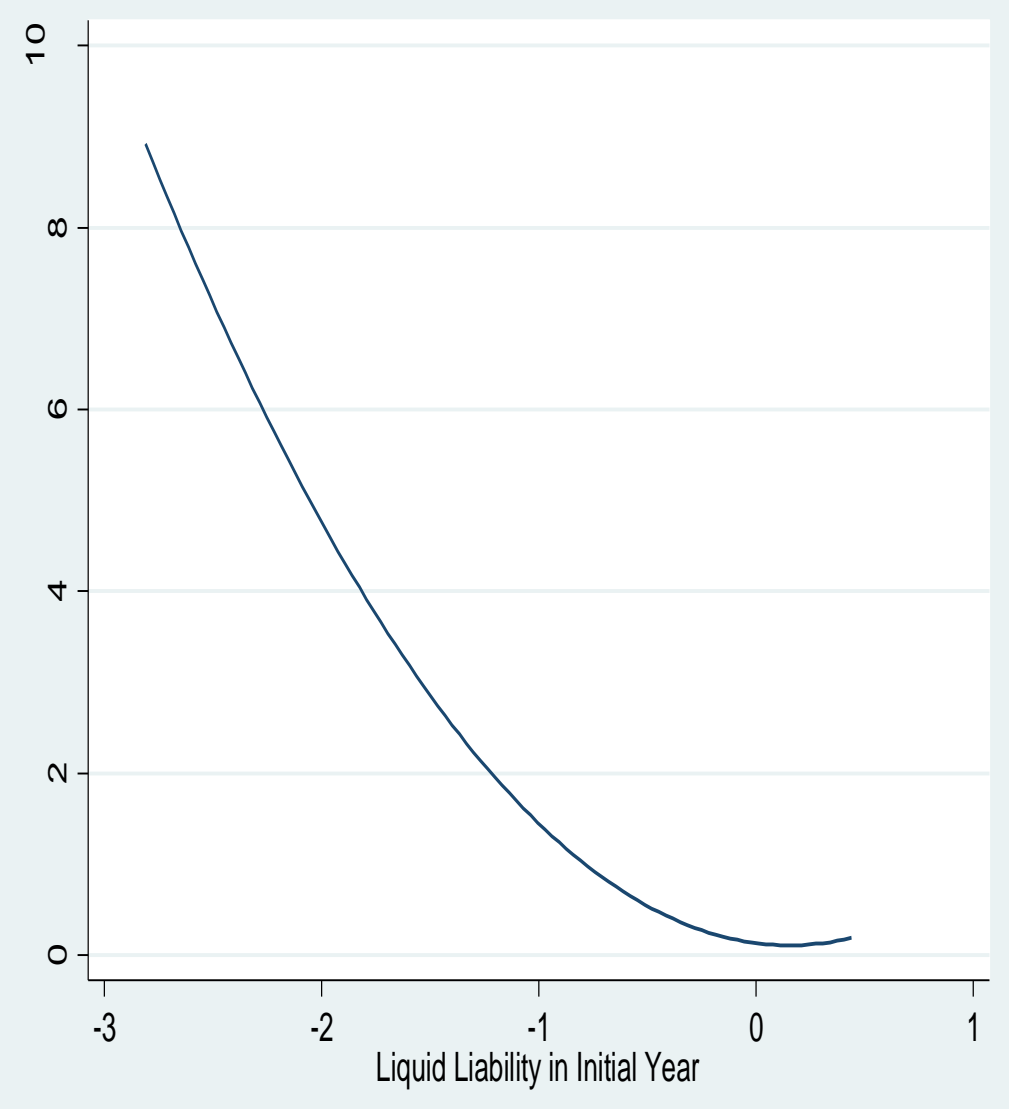


Figure 4.14: Fitted Graph for Whole Sample (with no cross term with Developed Country Dummy)

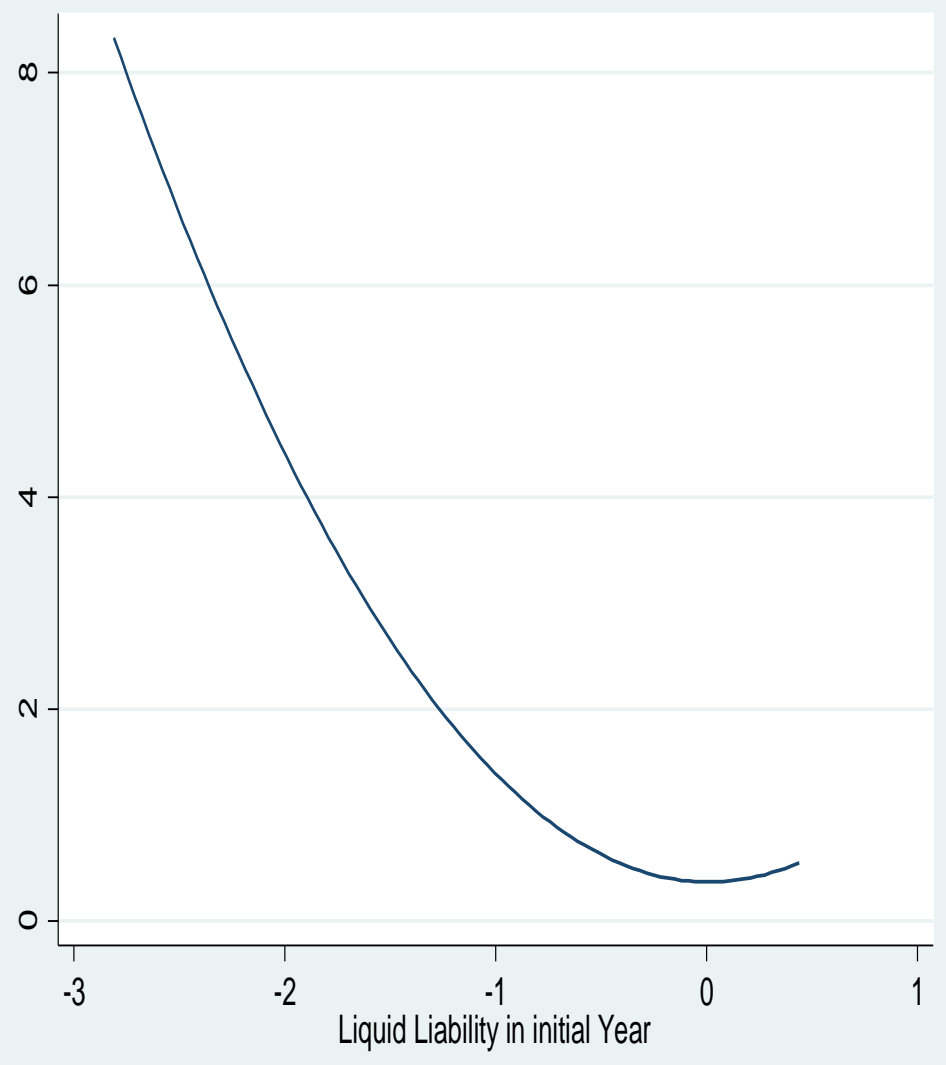


Figure 4.15: Fitted Graph for Developing Countries

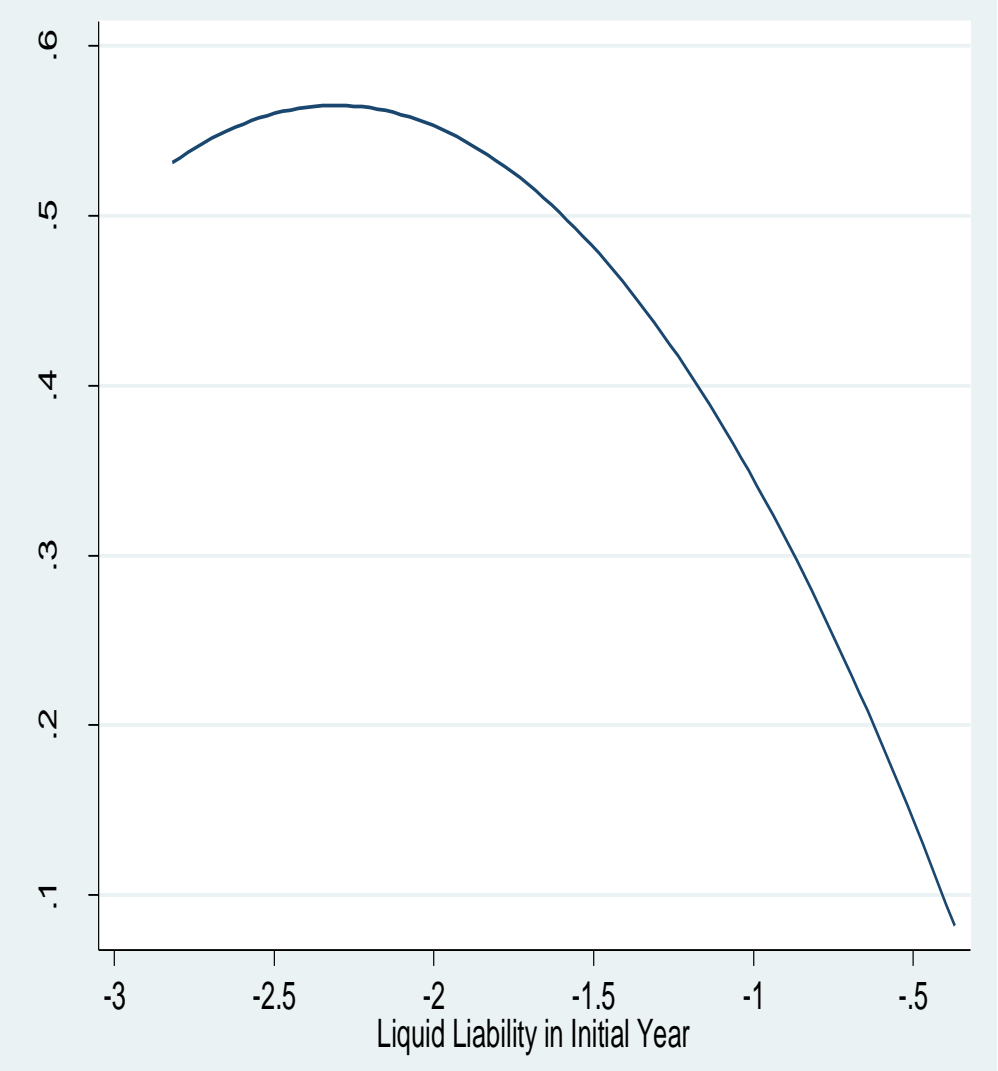


Figure 4.16: Fitted Graph for Developed countries

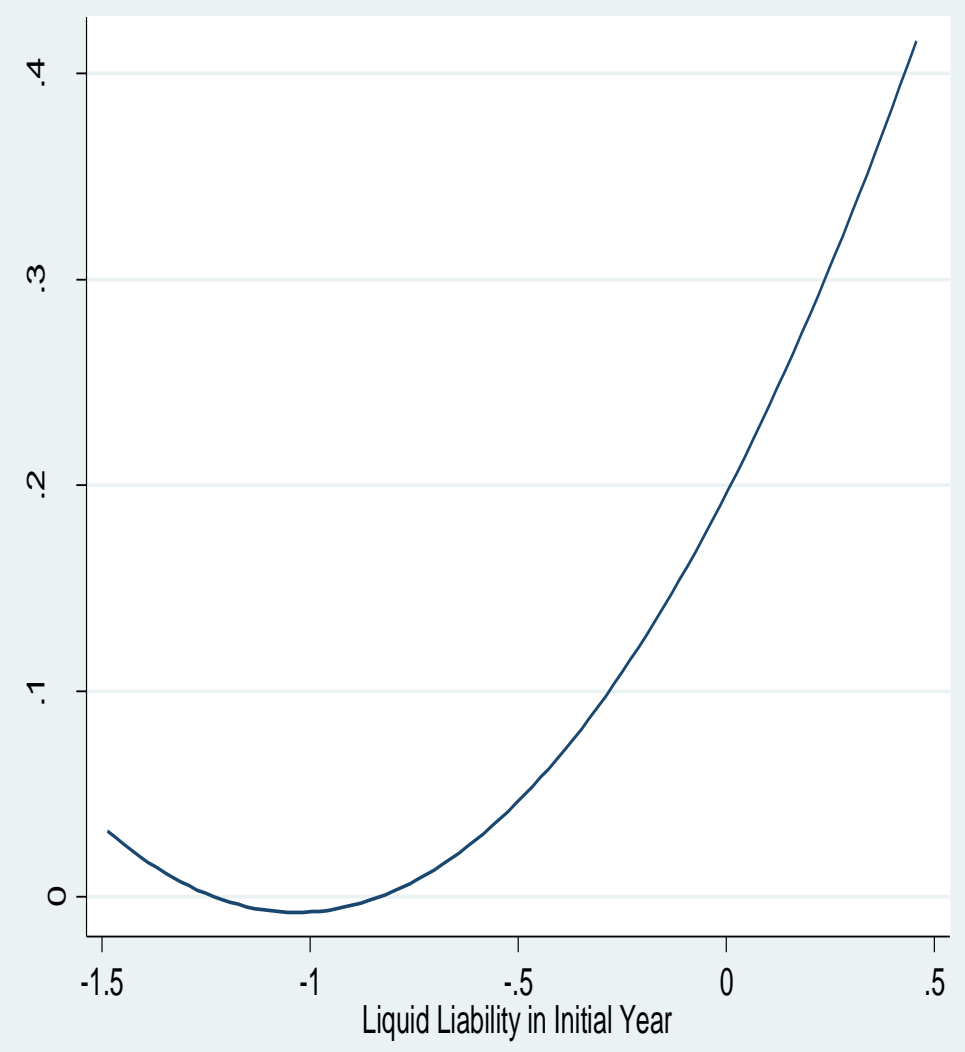




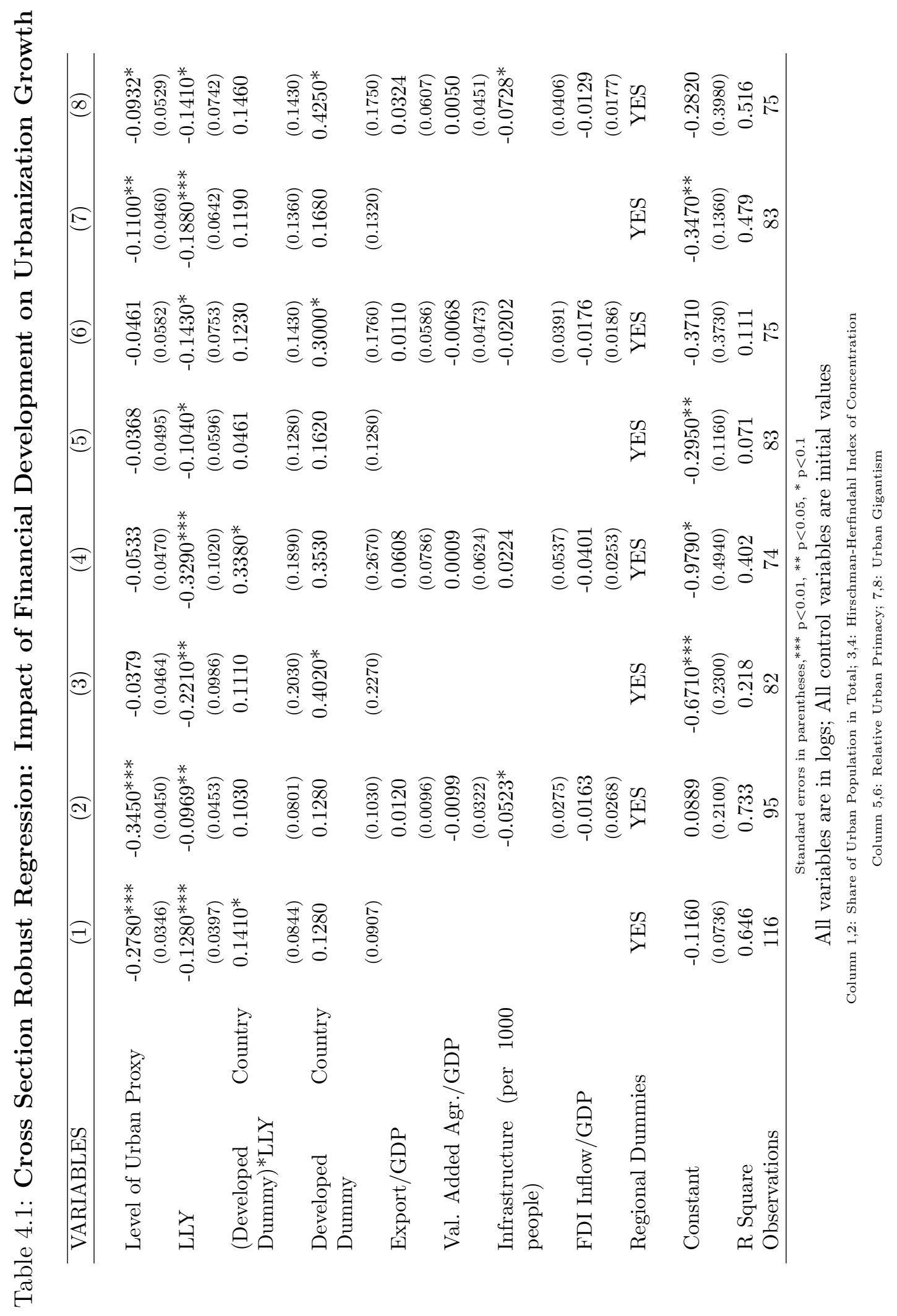




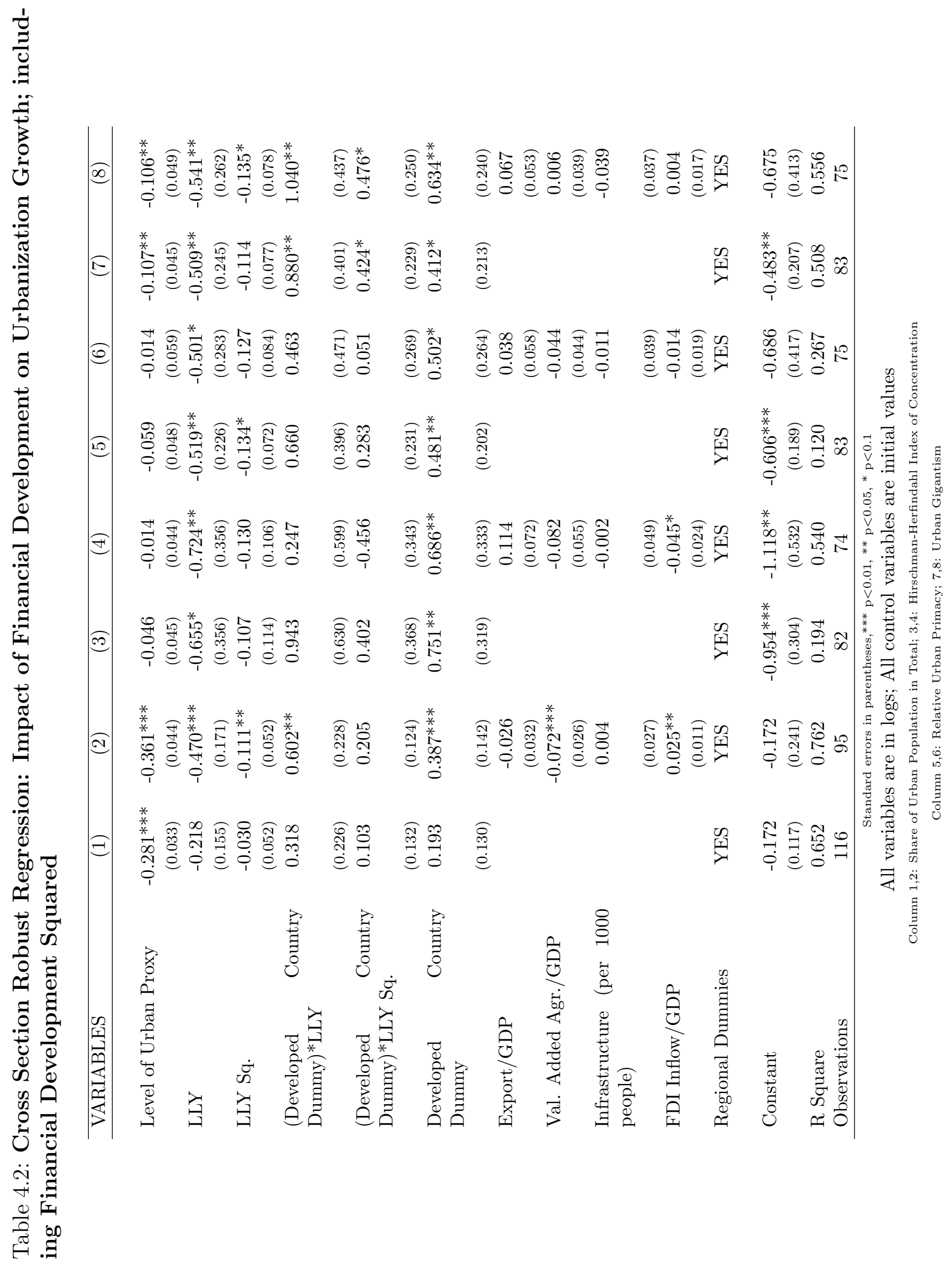




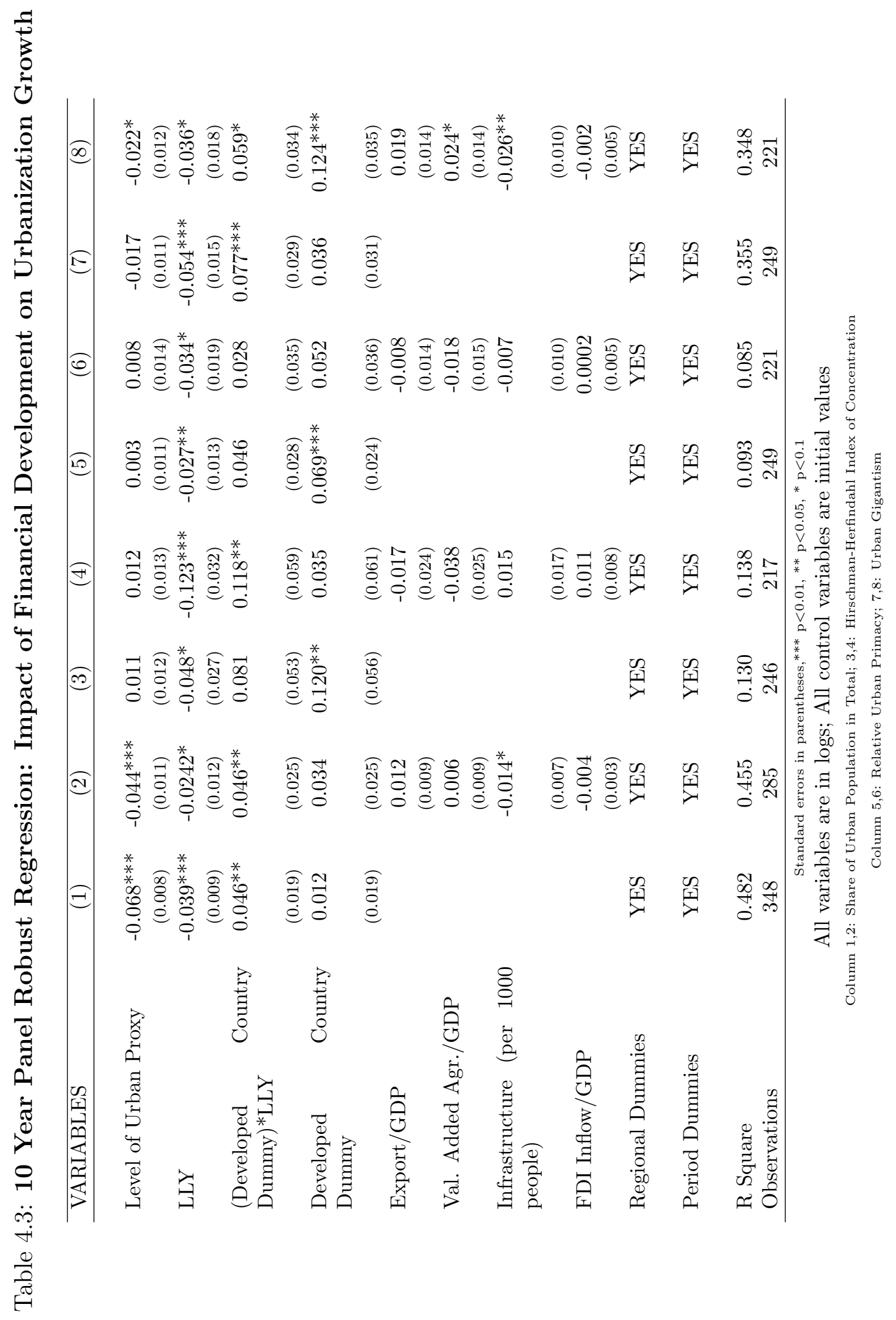




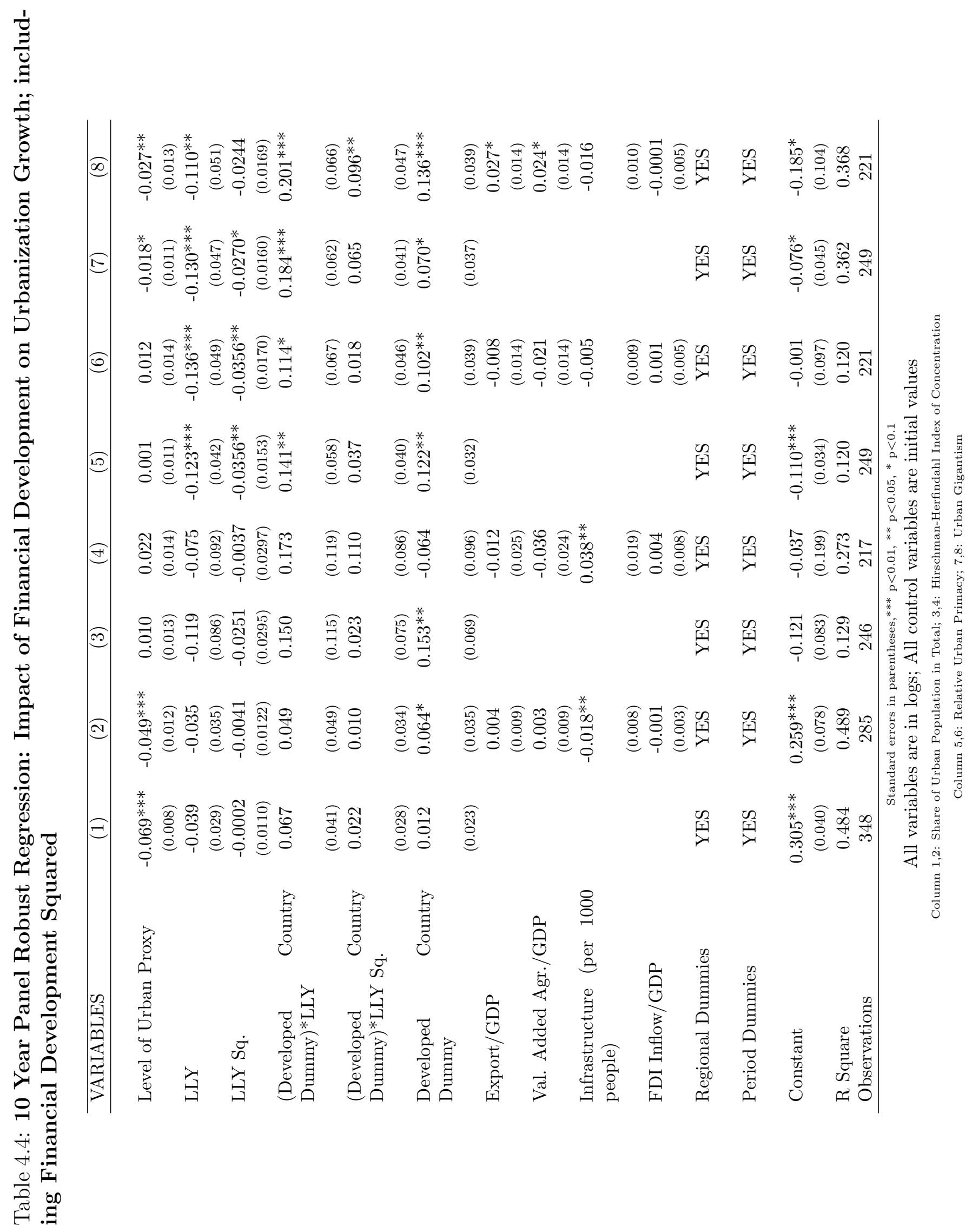




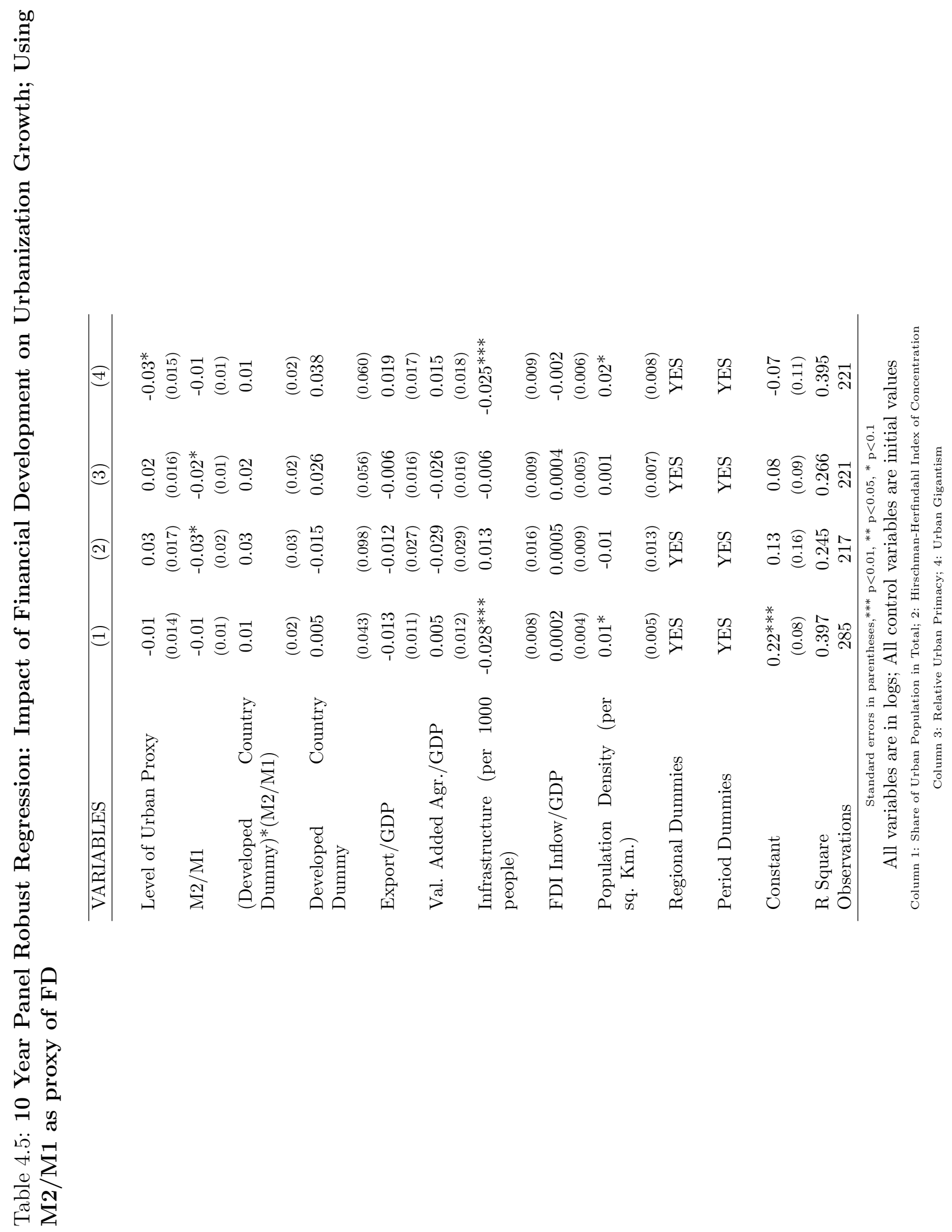


Table 4.6: List of Countries

\begin{tabular}{|l|l|l|}
\hline Algeria & France & Pakistan \\
\hline Argentina & Gabon & Panama \\
\hline Australia & Gambia, The & Papua New Guinea \\
\hline Austria & Germany & Paraguay \\
\hline Bahamas, The & Ghana & Peru \\
\hline Bahrain & Greece & Philippines \\
\hline Bangladesh & Grenada & Poland \\
\hline Barbados & Guatemala & Portugal \\
\hline Belgium & Haiti & Rwanda \\
\hline Belize & Honduras & Saudi Arabia \\
\hline Benin & Hungary & Senegal \\
\hline Bolivia & Iceland & Seychelles \\
\hline Botswana & India & Sierra Leone \\
\hline Brazil & Indonesia & Singapore \\
\hline Bulgaria & Iran & Solomon Islands \\
\hline Burkina Faso & Ireland & South Africa \\
\hline Burundi & Israel & Spain \\
\hline Cameroon & Italy & Sri Lanka \\
\hline Canada & Jamaica & St. Kitts and Nevis \\
\hline Cape Verde & Japan & St. Lucia \\
\hline Central African Republic & Jordan & St. Vincent and the Grenadines \\
\hline Chad & Kenya & Sudan \\
\hline Chile & Korea, Republic & Suriname \\
\hline China & Kuwait & Swaziland \\
\hline Colombia & Lesotho & Sweden \\
\hline Congo, Rep. & Madagascar & Switzerland \\
\hline Costa Rica & Malawi & Syria \\
\hline Cote D' Ivore & Malaysia & Tanzania \\
\hline Cyprus & Malta & Thailand \\
\hline Denmark & Mauritius & Togo \\
\hline Dominica & Mexico & Tonga \\
\hline Dominican Rep. & Morocco & Trinidad and Tobago \\
\hline Ecuador & Myanmar & Turkey \\
\hline Egypt & Nepal & United Kingdom \\
\hline El Salvador & Netherlands & United States \\
\hline Rquitorial Guinea & New Zealand & Uruguay \\
\hline Ethiopia & Niger & Venezuela \\
\hline Fiji & Nigeria & Zambia \\
\hline Finland & Norway & Zimbabwe \\
\hline & & \\
\hline
\end{tabular}


Table 4.7: Summary Statistics

\begin{tabular}{|c|c|c|c|c|}
\hline Variables & Mean & Standard Dev. & Minimum & Maximum \\
\hline \multicolumn{5}{|c|}{ Whole Sample } \\
\hline H-F Index 1975 & -2.37318 & 0.972393 & -5.35807 & 0 \\
\hline Growth in H-F index & -0.22558 & 0.424339 & -1.62257 & 0.909109 \\
\hline Share of Urban Population to Total 1975 & -1.04334 & 0.73517 & -3.44202 & 0 \\
\hline Growth in Share of Urban Population to Total & 0.343196 & 0.325204 & -0.25572 & 1.581945 \\
\hline Relative Urban Population 1975 & -1.29234 & 0.590362 & -3.08027 & -0.00018 \\
\hline Growth in Relative Urban Population & -0.10398 & 0.225696 & -0.72613 & 0.473243 \\
\hline Urban Gigantism 1975 & -2.23754 & 0.868474 & -4.82897 & -0.00018 \\
\hline Growth in Urban Gigantism & 0.233901 & 0.327334 & -0.51733 & 1.444853 \\
\hline (Liquid Liability/GDP) 1975 & -1.20091 & 0.608651 & -2.81938 & 0.457196 \\
\hline GDP per capita (constant US \$ 2000) & 7.434433 & 1.496411 & 4.638243 & 10.17696 \\
\hline EXP/GDP & 3.208166 & 0.709483 & 1.063012 & 4.821156 \\
\hline Value Added of Agriculture & 2.72422 & 1.054412 & -1.60944 & 4.273268 \\
\hline Telephone Mainlines (per 1000) & 2.872733 & 1.86077 & -0.90748 & 6.2417 \\
\hline FDI inflow/GDP & -0.50904 & 1.798426 & -6.52605 & 3.224232 \\
\hline \multicolumn{5}{|c|}{ Developing Countries } \\
\hline H-F Index 1975 & -2.32265 & 0.846892 & -4.72745 & -0.94001 \\
\hline Growth in H-F index & -0.28252 & 0.444236 & -1.62257 & 0.729796 \\
\hline Share of Urban Population to Total 1975 & -1.27201 & 0.708817 & -3.44202 & -0.16252 \\
\hline Growth in Share of Urban Population to Total & 0.421365 & 0.336407 & -0.25572 & 1.581945 \\
\hline Relative Urban Population 1975 & -1.25201 & 0.535878 & -3.08027 & -0.46887 \\
\hline Growth in Relative Urban Population & -0.13129 & 0.235025 & -0.72613 & 0.366219 \\
\hline Urban Gigantism 1975 & -2.45697 & 0.84941 & -4.82897 & -0.87608 \\
\hline Growth in Urban Gigantism & 0.311004 & 0.352668 & -0.51733 & 1.444853 \\
\hline (Liquid Liability/GDP) 1975 & -1.38864 & 0.536868 & -2.81938 & -0.33639 \\
\hline GDP per capita (constant US \$ 2000) & 6.813254 & 1.146017 & 4.638243 & 9.627213 \\
\hline EXP/GDP & 3.174034 & 0.759442 & 1.063012 & 4.821156 \\
\hline Value Added of Agriculture & 3.039064 & 0.831696 & -0.06872 & 4.273268 \\
\hline Telephone Mainlines (per 1000) & 2.050239 & 1.410518 & -0.90748 & 4.793558 \\
\hline FDI inflow/GDP & -0.46789 & 1.925561 & -6.52605 & 3.224232 \\
\hline \multicolumn{5}{|c|}{ Developed Countries } \\
\hline H-F Index 1975 & -2.49041 & 1.227486 & -5.35807 & 0 \\
\hline Growth in H-F index & -0.09348 & 0.347146 & -0.79868 & 0.909109 \\
\hline Share of Urban Population to Total 1975 & -0.38019 & 0.245256 & -0.89649 & 0 \\
\hline Growth in Share of Urban Population to Total & 0.116506 & 0.126225 & 0 & 0.520776 \\
\hline Relative Urban Population 1975 & -1.38231 & 0.700131 & -2.87491 & -0.00018 \\
\hline Growth in Relative Urban Population & -0.04305 & 0.193867 & -0.48634 & 0.473243 \\
\hline Urban Gigantism 1975 & -1.74804 & 0.705825 & -3.19374 & -0.00018 \\
\hline Growth in Urban Gigantism & 0.0619 & 0.166115 & -0.30624 & 0.520153 \\
\hline (Liquid Liability/GDP) 1975 & -0.66277 & 0.469209 & -1.48667 & 0.457196 \\
\hline GDP per capita (constant US \$ 2000) & 9.276551 & 0.655906 & 7.819807 & 10.17696 \\
\hline EXP/GDP & 3.309386 & 0.533267 & 2.144836 & 4.416556 \\
\hline Value Added of Agriculture & 1.801402 & 1.108494 & -1.60944 & 3.300715 \\
\hline Telephone Mainlines (per 1000) & 5.148301 & 0.67355 & 3.400862 & 6.2417 \\
\hline FDI inflow/GDP & -0.60355 & 1.494869 & -5.84873 & 1.739461 \\
\hline
\end{tabular}




\section{Chapter 5}

\section{Conclusion}

The essays of my dissertation explore and emphasize roles good institutions have in the context of economic development. As mentioned in the beginning, good institutions is what explains the vast difference in performance of countries across the globe. Keeping in mind that, the essays in the dissertation identifies factors that can lead to establishment of good institutions and elaborates how presence of good institutions can alter developmental outcomes in countries. The general consensus of these essays is thus that good institutions are the necessity for countries to fulfill their developmental objectives.

The first essay establishes that higher inflow of FDI to an economy has a positive spillover effect on its media sector. It significantly enhances media freedom. FDI in an economy strengthens all its institutions and the general socio-economic framework. The higher level of FDI inflow within a country has its share of impact on media sector as well, which is one of the most important and sensitive institutions. The positive spill-over effect works by removing information asymmetry, bringing financial independence, bestowing technological superiority, enhancing quality and reach and raising public awareness. These, in turn, pave the way for a free and potent media. The results establish FDI inflow as an important contributor to media freedom. The higher the flow of FDI into an economy, the free-er and more efficient is the media. 
The second essay iterates the importance of a free press in the context of combating the most dreadful threat faced by countries in current times - terrorism. Considering the case of transnational terrorism, the robust analysis presented above establishes that a free press does have a mitigating impact on terrorism. The importance of the paper extends further to substantiate that, though a democracy has often been criticized to be terror-inviting, when empowered by a free press, the two together have a strong terror dampening effect. The analysis is not only important as it upholds the importance of having a free press and a sound democracy, but also establishes how important it is to empower a democracy with a free press and this definitely has sound policy implications. This is especially for countries weaker on either front as also for all countries plagued by threats or actual incidents of terrorism. It also refutes the doubt that lurked about the role of a free press in dealing with the 26/11 terror incident in India. Considering the detailed analysis, it can be safely claimed that the free press led to a positive impact at the end of it, if anything.

The third essay examines the extent to which the level of a country's financial development plays a contributory role in determining the pace of urbanization and urban concentration in different countries. The analysis shows that a higher level of financial development is associated with a lower growth in urbanization and urban concentration. The empirical analysis also concludes that the latter result is mostly driven by the experience observed in developing countries. Given that developing nations in the past decades have witnessed excess and fast paced urbanization and concentration, it is an important insight to see that development of the financial intermediary sector can help the countries decongest and embark on a process of desired and structured urbanization. 


\section{Bibliography}

Abadie, A., "Poverty, Political Freedom, and the Roots of Terrorism," American Economic Review Papers and Proceedings, 2006, 96, 50-56.

- and J. Gardeazabal, "Terrorism and the World Economy," European Economic Review, 2008, 52, 1-27.

Ades, A. F. and E. L. Glaeser, "Trade and Circuses: Explaining Urban Giants," 1995. National Bureau of Economic Research, Working Paper Series, Working Paper 4715.

Alesina, A., A. Devleeschauwer, W. Easterly, S. Kurlat, and R. Wacziarg, "Fractionalization," Journal of Economic Growth, 2003, 8, 155-194.

Alfaro, Laura, Areendam Chanda, Sebnem Kalemli-Ozcan, and Selin Sayek, "FDI Spillovers, Financial Markets and Economic Development," 2003. IMF Working Papers $03 / 186$.

Antrop, M., "Changing Landscape in the Urbanized Countryside of Western Europe," Landscape Ecology, 2000, 15, 257-270.

Arestis, P., P. O. Demetriades, and K. B. Luintel, "Credit and Banking, Financial Development and Economic Growth: The Role of Stock Market," Journal of Money, Credit and Banking, 2001, 33, 16-41.

Bairoch, P., Cities and Economic Development 1988. Univ. of Chicago Press, Chicago.

Balasubramanyam, V. N., M. Salisu, and David Sapsford, "Foreign Direct Investment and Growth in EP and IS Countries," The Economic Journal, 1996, 106, 92-105.

Bandyopadhyay, S. and J. Younas, "What Spurs Terrorism in Developing Nations," 2009. Federeal Reserve Bank of St. Louis Working paper no: 2009-023B.

Bank, World, "World Development Indicators," 2005.

_ , "World Development Indicators," 2007.

Barro, Robert J. and Jong-Wha Lee, "International Data on Educational Attainment: Updates and Implications," 2000. Working Paper No. 42. 
Barry, Frank, Holger Gorg, and Eric Strobl, "Foreign Direct Investment, Agglomerations, and Demonstration Effects: An Empirical Investigation," Review of World Economics, 2004, 127, 583-600.

Beck, T., "Financial Development and International Trade: Is There a Link?," Journal of International Economics, 2002, 57, 107-131.

_ , R. Levine, and N. Loayza, "Finance and the Sources of Growth," Journal of Financial Economics, 2000, 58, 261-300.

Beck, Thorsten, Asli Demirg-Kunt, and Ross Levine, "A New Database on Financial Development and Structure," World Bank Economic Review, 2000, 14, 597-605.

_, Asli Demirguc-Kunt, and Ross Eric Levine, "Financial Institutions and Markets Across Countries and over Time: Data and Analysis," 2002. World Bank Policy Research Working Paper No. 4943.

Becker, B., "City Size and Financial Development," 2006. Swedish Institute for Financial Research.

Benhabib, Jess and Mark M. Spiegel, "The Role of Financial Development in Growth and Investment," 2000.

Besley, Timothy and Robin Burgess, "The Political Economy of Government Responsiveness: Theory and Evidence from India," Quarterly Journal of Economics, 2002, 117, $1415-1452$.

Blomberg, S. B. and G. D. Hess, "The Lexus and the Olive Branch: Globalization, Democratization and Terrorism," 2005. Mimeo, Claremont Colleges.

_ , _ , and A. Weerapana, "Economic Conditions and Terrorism," European Journal of Political Economy, 2004, 20, 463-478.

Bolbol, A., A. Fatheldin, and M. M. Omran, "Financial Development, Structure, and Economic Growth: The Case of Egypt, 1974-2002," Research in International Business and Finance, 2005, 19, 171-194.

Borensztein, E., J. De Gregorio, and J-W Lee, "How does foreign direct investment affect economic growth?," Journal of International Economics, 1998, 45, 115-135.

Bosworth, Barry P., Susan M. Collins, and Carmen M. Reinhart, "(C)apital (F)lows to (D)eveloping (E)conomies: (I)mplications for (S)avings and (I)nvestment," 1999. (B)rookings (P)apers on (E)conomic (A)ctivity (1).

Buckley, Robert M., Patricia Clarke Annez, and Michael Spence, Urbanization and Growth, World Bank Publication, 2009.

Burgoon, B., "On Welfare and Terror: Social Welfare Policies and Political-Economic Roots of Terrorism," Journal of Conflict Resolution, 2006, 50, 176-203. 
Chavunduka, Mark, The Right to Tell: The Role of Mass Media in Economic Development, Washington D.C.: The World Bank,

Chowdhury, Shyamal K., "The Effect of Democracy and Press Freedom on Corruption:An Empirical Test," Economic Letters, 2004, 85, 93-101.

Coyne, Christopher and Peter T. Leeson, "Read All About It! Understanding the Role of Media in Economic Development," Kyklos, 2004, 57, 21-44.

_ and _ , "Manipulating the Media," Institutions and Economic Development, 2005, 1, $67-92$.

_ and _, Media,Development and Institutional Change, Edward Elgar Publishing, 2008.

Dadush, U., D. Dasgupta, and D. Ratha, "The Role of Short-Term Debt in Recent Crisis," Finance and Development, 2000, 37, 54-57.

Dawson, John W., "Institutions, Investment, and Growth: New Cross-Country and Panel Data Evidence," Economic Inquiry, 1998, 36, 603-623.

Dehejia, Rajeev and Adriana Lleras-Muney, "Financial Development and Pathways of Growth: State Branching and Deposit Insurance Laws in The United States From 1900 To 1940," Journal of Law and Economics, 2005, 50, 239-272.

Demetraides, P. O. and K. A. Hussein, "Does Financial Development Cause Economic Growth? Time-Series Evidence from 16 Countries," Journal of Development Economics, 1996, 51, 387-411.

Djankov, Simeon, Tatiana Nenova Caralee McLiesh, and Andrei Shleifer, "Who Owns the Media?," Journal of Law and Economics, 2003, 46, 341-382.

Drakos, K. and A. Gofas, "In Search of the Average Transnational Terrorist Attack Venue," Defence and Peace Economics, 2006a, 17.

Egorov, Georgy, Sergei Guriev, and Konstantin Sonin, "Media Freedom, Bureaucratic Incentives, and the Resource Curse," 2007. Working Paper, Center for Economic and Financial Research (CEFIR).

Eichenberger, Reiner and Bruno S. Frey, "Democratic Governance for a Globalized World," Kyklos, 2002, 55, 265-287.

Elizondo, R. L. and P. Krugman, "Trade Policy and the Third World Metropolis," 1998. National Bureau of Economic Research, Working Paper Series, Working Paper 4238.

Enders, W. and T. Sandler, "An Economic Perspective on Transnational Terrorism," European Journal of Political Economy, 2004, 20, 301-316.

_ and _, The Political Economy of Terrorism, Cambridge University Press: Cambridge, UK, 2006. 
Eubank, W. and L. Weinberg, "Terrorism and Democracy: Perpetrators and Victims," Terrorism and Political Violence, 2001, 13, 155-164.

Eyerman, J., "Terrorism and Democratic States: Soft Targets or Accessible Systems," International Interactions, 1998, 24, 151-170.

Feldstein, Martin, "Aspects of Global Economic Integration: Outlook for the Future," 2000. NBER Working Papers 7899.

Gallego, S., A. G. Herrero, and J. Saurina, "The Asian and European Banking Systems:The Case of Spain in the Quest for Development and Stability," 2002. KOBE Research Project.

Gallup, J. L., J. D. Sachs, and A. Mellinger, "Geography and Economic Development," International Regional Science Review, 1999, 22, 179-232.

Gustavsson, R., "Explaining the Phenomenon of Third World Urban Giants," Journal of Economic Integration, 1999, 14.

Henderson, Vernon J., Handbook of Economic Growth, Brown University, 2004. Volume 1.

Hermes, N. and R. Lensink, "Foreign Direct Investment, Financial Development and Economic Growth," Journal of Development Studies, 2003, 40.

Hsu, C. M. and S. M. Lin, "Industry of Free China, Financial Development and Endogenous Growth Model," 2002.

Islam, Roumeen, The Right to Tell: The Role of Mass Media in Economic Development, Washington D.C.: The World Bank,

Jayaratne, J. and Philip E. Strahan, "The Finance-Growth Nexus: Evidence from Bank Branch Deregulation," Quarterly Journal of Economics, 1996, 111.

Kassem, Hisham, The Right to Tell: The Role of Mass Media in Economic Development, Washington D.C.: The World Bank,

Keefer, P. and N. Loayza, Terrorism, Economic Development, and Political Openness, Cambridge University Press, 2008.

King, Robert J. and Ross Levine, "Finance and Growth: Schumpeter Might Be Right," Quarterly Journal of Economics, 1993, 108.

_ and _ , "Finance, Entrepreneurship and Growth: Theory and Evidence," Journal of Monetary Economics, 1993, 32.

Kmenta, J., Elements of Econometrics, University of Michigan Press, MI, Ann Arbor, 1997. 
Krueger, A. B. and D. D. Laitin, "Kto Kogo?: A Cross-Country Study of the Origins and Targets of Terrorism," 2007.

- and J. Maleckova, "Education, Poverty and Terrorism: Is There a Causal Connection," Journal of Economic Perspective, 2003, 17, 119-144.

Kurrild-Klitgaard, P., M.K. Justesen, and P. Klemmensen, "The Political Economy of Freedom, Democracy and Transnational Terrorism," Public Choice, 2006, 128, 289-315.

Lensink, R. and O. Morrissey, "FDI Flows, Volatility and Growth," 2001. University of Nottingham: CREDIT Research Paper 01/06.

Levine, Ross, "Financial Development and Economic Growth: Views and Agenda," Journal of Economic Literature, 1997, 35, 513-542.

_, Norman Loayza, and Thorsten Beck, "Financial Intermediation and Growth: Causality and Causes," Journal of Monetary Economics, 2000, 46.

Levitt, Steven D., "Using Electoral Cycles in Police Hiring to Estimate the Effect of Police on Crime: Reply," American Economic Review, 2002, 92, 1244-50.

Li, Q., "Does Democracy Promote or Reduce Transnational Terrorist Incidents?," Journal of Conflict Resolution, 2005, 49.

- and D. Schaub, "Economic Globalization and Transnational Terrorism: A Pooled TimeSeries Analysis," Journal of Conflict Resolution, 2004, 48, 230-258.

Lipsey, Robert, "Interpreting Developed Countries' Foreign Direct Investment," 2000. NBER Working Papers 7810.

_, "Foreign Direct Investment and the Operations of Multinational Firms: Concepts, History, and Data," 2001. NBER Working Papers 8665.

- and Fredrik Sjholm, "Host Country Impacts Of Inward FDI: Why Such Different Answers ?," 2004. EIJS Working Paper Series 192.

Lucas, R. E., "On the Mechanics of Economic Development," Journal of Monetary Economics, 1988, 12, 3-42.

Mehfuz, A., The Right to Tell: The Role of Mass Media in Economic Development, Washington D.C.: The World Bank,

Mickolous, E. F., T. Sandler, and J. M. Murdock, "International Terrorism: Attributes of Terrorist Events, 1968 - 2003, ITERATE," 2003.

Mills, Edwin S. and Byung Nak Songs, Urbanization and Urban Problems, Harvard University Press: Cambridge, MA, 1979.

Moomaw, R. L. and Ali M. Shatter, "Urbanization as a Factor in Economic Growth: An Empirical Study," Journal of Economics, 1993, 19, 1-6. 
_ and _ , "Urbanization and Economic Development: A Bias toward Large Cities?," Journal of Urban Economics, 1996, 40.

- and M. Alwosabi, "An Empirical Analysis of Competing Explanations of Urban Primacy: Evidence from Asia and the Americas," The Annals of Regional Science, 2004, 38, $149-171$.

_ and _ , "Urban Primacy, Gigantism and International Trade: Evidence from Asia and the Americas," Journal of Economic Integration, 2007, 22.

Murray, Michael P., "Avoiding Invalid Instruments and Coping with Weak Instruments," Journal of Economic Perspectives, 2006, 20, 111-132.

Neusser, Klaus and Maurice Kugler, "Manufacturing Growth and Financial Development: Evidence from OECD Countries," Review of Economics and Statistics, 1998, 80.

Nieswiadomy, Michael L. and Mark C Strazicich, "Are Political Freedoms Converging?," Economic Inquiry, 2004, 42, 323-341.

Nkusu, Mwanza and Selin Sayek, "Local Financial Development and Aid-Growth Relationship," 2004. IMF Working Papers.

Ottens, L. and F. Henk, "An Interpretation of Recent Trends in Urbanization in the Netherlands," Journal of Housing and Built Environment, 1990, 5.

Outreville, J. Franois, "Financial Development, Human Capital and Political Stability," 1999. UNCTAD Discussion Papers, United Nations Conference on Trade and Development, No. 142.

Parr, John B. and Leslie Budd, "Financial Services and the Urban System: An Exploration," Urban Studies, 2000, 37.

Porta, Rafael La, Florencio Lopez de Silanes, Andrei Shleifer, and Robert W. Vishny, "Law and Finance," Journal of Political Economy, 1998, 106.

Rajan, R. G. and L. Zingales, "Financial Dependence and Growth," American Economic Review, 1998, 88, 559-586.

Roeder, Philip G., "Ethnolinguistic Fractionalization (ELF) Indices, 1961 and 1985," 2001.

Rose, A., "Well-Being in the Small and in the Large: Dataset," 2006.

Rousseau, Peter L. and Paul Wachtel, "Financial Intermediation and Economic Performance: Historical Evidence from Five Industrial Countries," Journal of Money. Credit, and Banking, 1998, 30.

Sachs, Jeffrey D. and Andrew M. Warner, "Natural Resource Abundance and Economic Growth," 1997. NBER Working Papers 5398. 
Schumpeter, J. A., The Theory of Economic Development, Harvard University Press: Cambridge, MA, 1934. translated by Redvers Opie,1934.

Shaw, E. S., Financial Deepening in Economic Development, Oxford University Press: New York, 1973.

Stiglitz, Joseph, The Right to Tell: The Role of Mass Media in Economic Development, Washington D.C.: The World Bank,

Todaro, M. P., Urban Development in the Third World, Greenwood Press:Westport, CT, 1979.

Trumbull, W. N. and H. J. Wall, "Estimating Aid Allocation Criteria with Panel Data," Economic Journal, 1994, 104, 876-882.

Vanhanen, T., Strategies of Democratization, Washington, DC: Crane Russak, 1992.

Wheaton, W. and H. Shishido, "Urban Concentration, Agglomeration Economies, and the Level of Economic Development," Economic Development and Cultural Change, 1981, $30,17-30$.

Wooldridge, J. M., Introductory Econometrics, South-Western Publishers, 2003.

Younas, J., "Motivation for Bilateral Aid Allocation: Altruism or Trade Benefits," European Journal of Political Economy, 2008, 24, 661-674.

Yu, Han and Pei-Tha Gan, "The Determinants of Banking Sector Development: Makaysian Experience," International Research Journal of Finance and Economics, 2010, 35. 


\section{CURRICULUM VITAE \\ SANJUKTA ROY}

\section{CONTACT INFORMATION}

Address: College of Business and Economics

Department of Economics

West Virginia University

P.O. Box 6025, Morgantown, WV 26506-6025, U.S.A.

Telephone: +1 3049069585

E-mail: saroy@mail.wvu.edu

\section{PERSONAL DATA}

Nationality: Indian

Visa Status: F1

\section{POSITION}

- May 2010 - Research Analyst: Media Map Project - World Bank Institute, Internews Network

\section{EDUCATION}

- Ph.D. in Economics

August 2010, West Virginia University

- Dissertation Topic: Three Essays on Institutions and Economic Development

- Dissertation Chair: Santiago M. Pinto

- Submission date: 07.31.2010

- M.A. in Economics

May 2003, Center for Economic Studies and Planning, Jawaharlal Nehru University, New Delhi, India 
- B.Sc.(Hons) in Economics

August 2001, Lady Brabourne College, University of Calcutta, Kolkata, India

\section{RESEARCH INTERESTS}

- Primary: Development Economics, International Economics

- Secondary: Urban Economics, Public Economics

\section{ACADEMIC EXPERIENCE}

Instructor (with full responsibility).

Duties included designing syllabus, teaching, designing and grading tests.

- Principles of Microeconomics: Spring 2008, Fall 2007

- Principles of Macroeconomics: Summer 2007, Spring 2007, Summer 2006

- Intermediate Macroeconomics: Fall 2008, Summer 2008, Summer 2009, Fall 2009

- Business Statistics: Summer 2009

- Personal Finance: Summer 2008 (Web Based Course)

Teaching Assistant: Advanced Microeconomics (Graduate Course)

\section{INDUSTRY EXPERIENCE}

- 2004-2005: Consultant Planning Commission, Perspective Planning Division, Government of India (Supervised by Dr. Pranab Sen, Chief Advisor to the Planning Commission; Dr. Archana Mathur, Director, Perspective Planning Division)

- 2003-2004: Trainee Consultant PricewaterhouseCoopers (P) Ltd., Kolkata, India.

\section{REFEREED PUBLICATIONS}


- The Impact of Financial Development on Domestic Investment: A Quantile Regression Approach (with N. Dutta), 2010. India Macroeconomics Annual, xxx.

- Beyond Borders: Is Media Freedom Contagious? (with R. Sobel and N. Dutta), 2009. Kyklos, 63(1), 123-133.

- What Attracts Foreign Direct Investment? (with N. Dutta), 2009. Economic Affairs, 29(3), 81-86.

- The Impact of Foreign Direct Investment on Press Freedom (with N. Dutta), 2009. Kyklos, 62(2), 239-257. This paper was awarded first prize for the Student Paper Competition at the MidWest Decision Science Institute Conference, 2008

- Foreign Direct Investment, Financial Development and Political Risks (with S. Roy), 2008. Journal of Developing Areas, forthcoming.

- Does a Free Press Nurture Entrepreneurship? (with R. Sobel and N. Dutta), 2010. Southern Journal of Entrepreneurship, forthcoming.

\section{PAPERS UNDER SUBMISSION}

- Do Potential Skilled Emigrants Care about Political Stability at Home? (with N. Dutta), under revise-resubmit.

- Fractionalization and Entrepreneurship: Does Cultural Diversity Increase The Rate Of Entrepreneurial Activity? (with R. Sobel and N. Dutta).

- Media Freedom Has Something More to Offer: The Impact of Media Freedom on Culture (with N. Dutta).

- Countering Terror: The Importance of a Free Press.

\section{RESEARCH IN PROGRESS}

- Counting on Financial Development for Urbanization (with S. M. Pinto).

- Another Role Foreign Aid must Play

- Media Freedom and Informal Institutions: Investigating the Causation Channels (with S. Roy). 
- Financial Development and Small Sector Enterprises: Are the Two Related? (with S. Roy).

- Is Tourism a Public Good? (with R. Sobel and S. Roy).

- How does Terrorism affect Informal Institutions? (with S. Roy).

- Does Terrorism Come in the Way of Financial Development? (with S. Roy).

- The PTA Factor: Role of Preferential Trade Agreement in the TradeInstitution Relation (with D. Mukherjee and S. Roy).

\section{CONFERENCE PRESENTATIONS}

- Terrorism, Institutions and the Role of a Free Press, University of Wisconsin La Crosse Seminar Series Guest Speaker, 2009

- Topics in Economic Development, Session Chair, Southern Economic Association Annual Meetings, 2009.

- Informal Institution and Media Freedom: Investigating the Causation Channels, Southern Economic Association Annual Meetings, 2009.

- Do Potential Skilled Emigrants Care about Political Stability at Home?, Centre for Studies in Social Sciences, Kolkata, India - joint presentation with N. Dutta, 2009.

- Counting on Financial Development for Urbanization, International Conference on Globalization, Agglomeration and Inclusive Growth organized by Jadavpur University, Kolkata, India and UNCTAD - New Delhi, India, 2009.

- Investigating the Channelization of Foreign Aid, Southern Economic Association Annual Meetings, 2008.

- Informal Institution and Media Freedom: Investigating the Causation Channels, Southern Economic Association Annual Meetings, 2008.

- The Role of Foreign Direct Investment on Press Freedom, Southern Economic Association Annual Meetings, 2008. 
- Foreign Aid, Financial Development and Economic Growth, Southern Economic Association Annual Meetings, 2007.

\section{HONORS AND AWARDS}

- 2009: Jon Vilasuso Advanced Doctoral Student Award, Department of Economics, West Virginia University

- 2008: Jon Vilasuso Doctoral Student Publication Award, Department of Economics, West Virginia University

- 2008: Awarded First Position in the Student Paper Competition at the MidWest Decision Science Institute Conference, 2008

- 2006-08: Dadisman Supplementary Scholarship for Advanced Students, Department of Economics, West Virginia University

\section{COMPUTER SKILLS}

- Statistical: STATA, SAS, Matlab,

- OS: Windows, Mac OS-X

\section{REFERENCES}

The following have agreed to provide references.

1. Dr. Santiago M. Pinto, Committee Chair

Address: College of Business and Economics

Department of Economics

West Virginia University

P.O. Box 6025, Morgantown, WV 26506-6025, U.S.A.

Telephone: (304) 2937871

E-Mail: Santiago.Pinto@mail.wvu.edu 
2. Professor Russell Sobel

Address: College of Business and Economics

Department of Economics

West Virginia University

P.O. Box 6025, Morgantown,

WV 26506-6025, U.S.A.

Telephone: (304) 2937864

E-Mail: $\quad$ Russell.Sobel@mail.wvu.edu

3. Professor Ronald Balvers

Address: College of Business and Economics

Department of Economics

West Virginia University

P.O. Box 6025, Morgantown,

WV 26506-6025, U.S.A.

Telephone: (304) 2937880

E-mail: $\quad$ Ronald.Balvers@mail.wvu.edu

4. Dr. Subhayu Bandyopadhyay

Address: Research Officer

Federal Reserve Bank of St. Louis

Telephone: (314) 4447425

E-mail: $\quad$ Subhayu.Bandyopadhyay@stls.frb.org 